\title{
Three empirical essays on environmental regulations, strategic interaction, and regional trade agreements
}

\author{
Paavo Eliste \\ West Virginia University
}

Follow this and additional works at: https://researchrepository.wvu.edu/etd

\section{Recommended Citation}

Eliste, Paavo, "Three empirical essays on environmental regulations, strategic interaction, and regional trade agreements" (2002). Graduate Theses, Dissertations, and Problem Reports. 1657.

https://researchrepository.wvu.edu/etd/1657

This Dissertation is protected by copyright and/or related rights. It has been brought to you by the The Research Repository @ WVU with permission from the rights-holder(s). You are free to use this Dissertation in any way that is permitted by the copyright and related rights legislation that applies to your use. For other uses you must obtain permission from the rights-holder(s) directly, unless additional rights are indicated by a Creative Commons license in the record and/ or on the work itself. This Dissertation has been accepted for inclusion in WVU Graduate Theses, Dissertations, and Problem Reports collection by an authorized administrator of The Research Repository @ WVU.

For more information, please contact researchrepository@mail.wvu.edu. 


\title{
Three Empirical Essays On Environmental Regulations, Strategic Interaction, And Regional Trade Agreements
}

\author{
Paavo Eliste \\ Dissertation submitted to the College of Agriculture, Forestry and \\ Consumer Sciences at West Virginia University in partial fulfillment of \\ the requirements for the degree of
}

\author{
Doctor of Philosophy \\ in \\ Natural Resources Economics \\ Jerald J. Fletcher, Ph.D., Chair \\ Per. G. Fredriksson, Ph.D. \\ Tim T. Phipps, Ph.D. \\ Dale K. Colyer, Ph.D. \\ Stratford M. Douglas, Ph.D. \\ John A. Dixon, Ph.D. \\ Morgantown, West Virginia \\ 2002
}

Keywords: Environmental regulations, Political economy, Trade liberalization, Regional Trade Agreements. 


\section{ABSTRACT \\ Three Empirical Essays On Environmental Regulations, Strategic Interaction, And Regional Trade Agreements}

\section{Paavo Eliste}

This dissertation will focus on the relationship between trade and the environment. We will analyze this from three angles. First, we explore the effect of trade liberalization on a country's environmental regulations at global level. Secondly, we focus on trade and political integration process at the regional level and how it affects block members environmental policies. Thirdly, we analyze whether polluting producers are compensated for environmental policies at the national level.

The analysis will focus on environmental regulations in the agricultural sector. We use spatial econometrics techniques to analyze policy outcomes, which are dependent on trade or political interactions between countries as a response to inter jurisdictional policy spillovers caused by trade liberalization policies.

We find no evidence that trade liberalization process has a negative impact on environmental regulations at global level. Empirical results show that countries with more open trade regimes tend to have also more stringent environmental regulations. This finding, however, is not uniform at the regional level where the integration process is generally deeper, which may shape the strategic interaction among countries. The results indicate that while regional trade integration process induces positive harmonization of environmental regulations among members of Custom Unions and regional trade agreements among high income countries, the impact of regional integration may be less evident or even divergent among the members of Free Trade Agreements and low-income countries. However, empirical results show that free trade 
may be indeed a powerful force to induce low income developing countries to upgrade their environmental policies towards those of high income countries.

Finally we analyze whether domestic producers get compensated for the costs associated with environmental regulations. We show that the existence of transfers can give counter-intuitive effects of environmental policy on both output and trade flows. In particular, the compensation obtained by producers neutralizes the effect of environmental policy on output, and consequently on trade flows. The empirical results support the hypothesis that environmental regulations and transfers are positively correlated. 


\section{ACKNOWLEDGEMENTS}

Completing this dissertation has been a great intellectual and personal challenge. I am deeply grateful for the support I received from my advisors, colleagues, family and friends. I am especially thankful for Professor Per Fredriksson from the Southern Methodist University for his guidance and advice, and for the invaluable support of my advisors Professors Jerry Fletcher, Tim Phipps, Dale Colyer and Stratford Douglas from the West Virginia University. I am especially grateful for my colleagues and friends John A. Dixon and Sari Söderström from the World Bank for their mentoring and keen

support. And finally I am extremely grateful for my wife Katrin for her patience and support. I would not have finished this dissertation without her personal sacrifices. 


\section{TABLE OF CONTENTS}

$\underline{\text { Page }}$

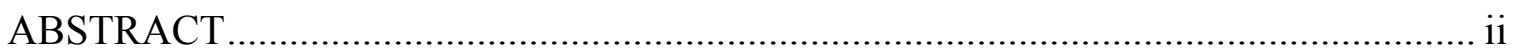

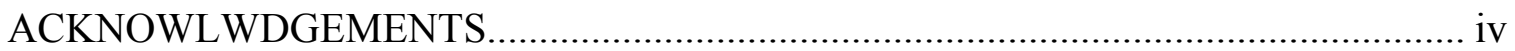

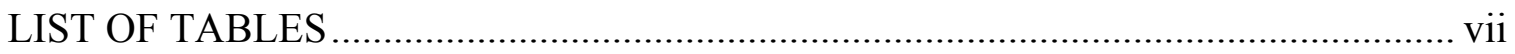

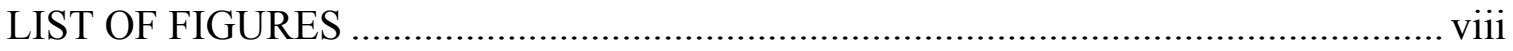

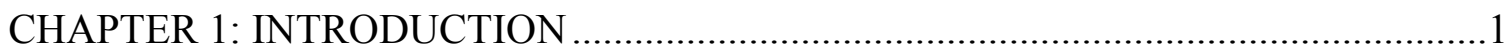

CHAPTER 2: ESSAY 1: Does Trade Liberalization Cause a Race-to-the-Bottom in Environmental Policies? A Spatial Econometric Analysis .......................................6

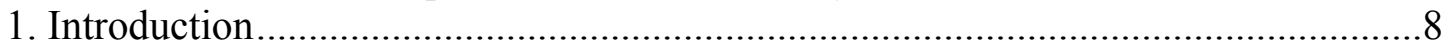

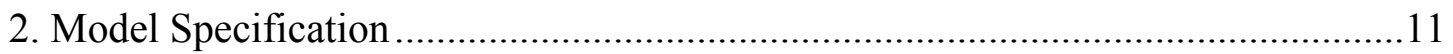

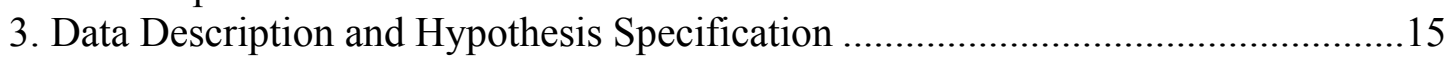

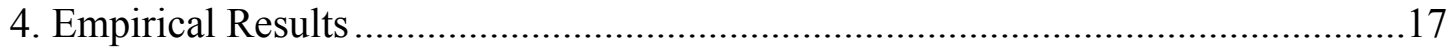

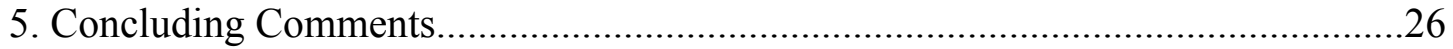

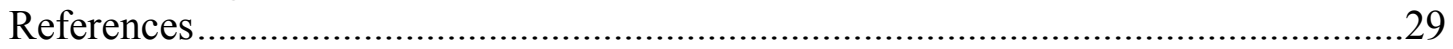

CHAPTER 3: ESSAY 2: Regional Trade Agreements and Coordination of

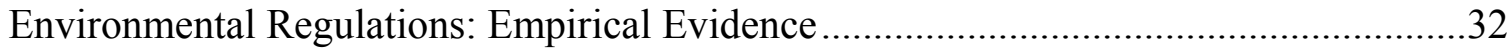

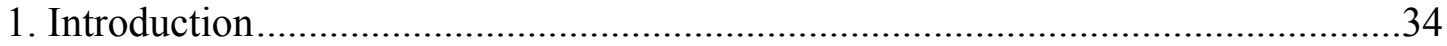

2. Regional Trade Agreements and Environmental Policy Harmonization.................. 37

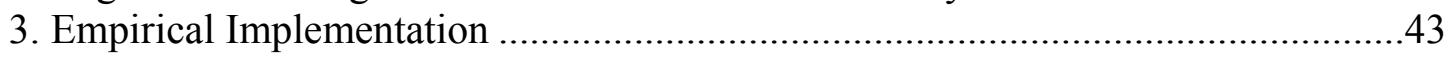

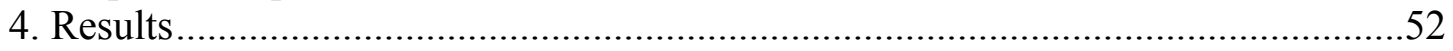

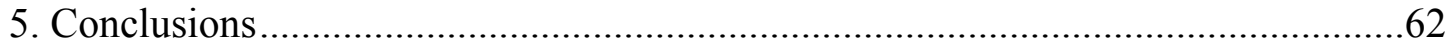

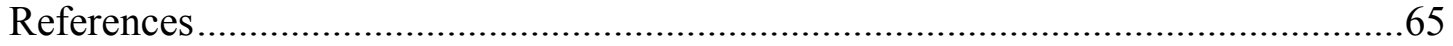

CHAPTER 4: ESSAY 3: Environmental Regulations, Transfers and Trade: Theory and

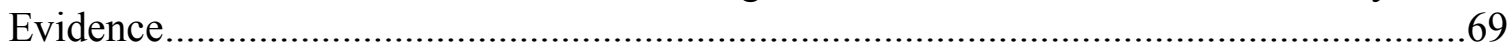

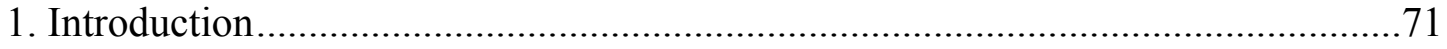

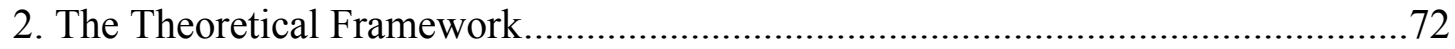

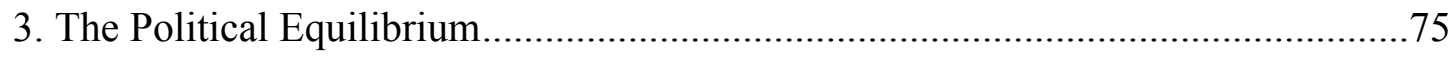

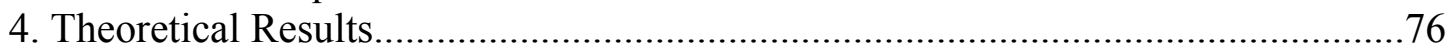

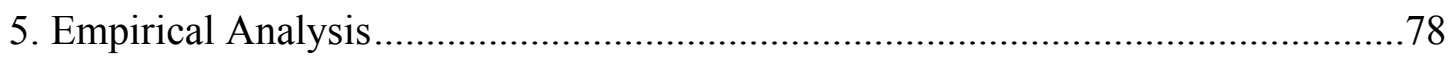

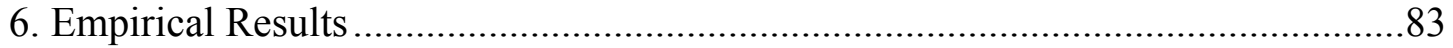

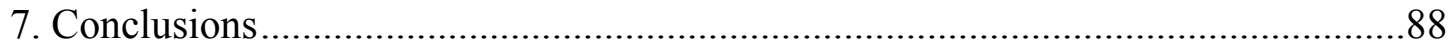

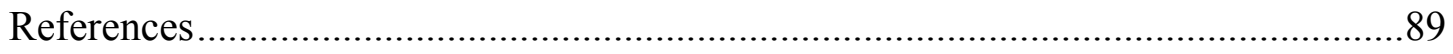




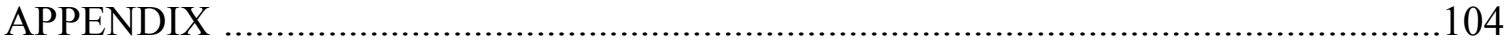

Table 1A: Definition of Regional Trade Agreements Used in Empirical Analysis ..104

Table 2A: Variable Definition and Data Sources .....................................................105

Index of the Stringency of Environmental Regulations...............................................106

Table 3A: Index of Stringency of Environmental Regulations in Agricultural Sector107

Table 4A: Descriptive Statistics of Variables..........................................................109

Table 5A: A Sample of Spatial Weight Matrix Based on Custom Unions.................110

Table 6A: List of Variables.................................................................................111

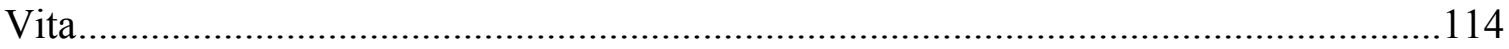




\section{LIST OF TABLES}

$\underline{\text { Essay } 1}$

$\underline{\text { Page }}$

Table 1: The Impact of Spatially Weighted Stringency of Environmental Regulations on

Domestic Environmental Regulations .....

\section{$\underline{\text { Essay } 2}$}

Table 1: Maximum Likelihood Estimates of RTAs.....................................................53

Table 2: Maximum Likelihood Estimates of Bilateral Trade Effects..............................60

\section{Essay 3}

Table I: Two-stage Least-squares Results (Heteroscedasticity Robust) ..........................84

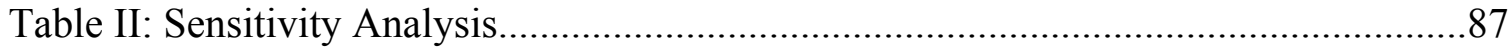

Table AI: Variable Definition and Data Sources ..........................................................95

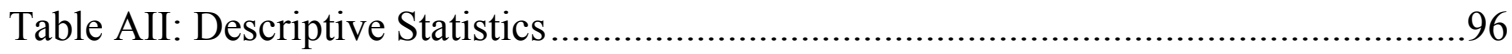




\section{LIST OF FIGURES}

$\underline{\text { Essay } 1}$

$\underline{\text { Page }}$

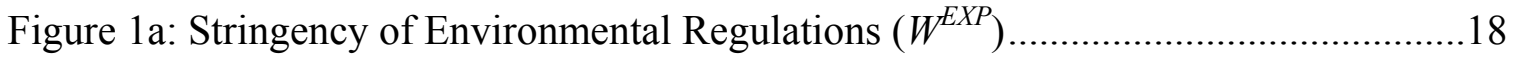

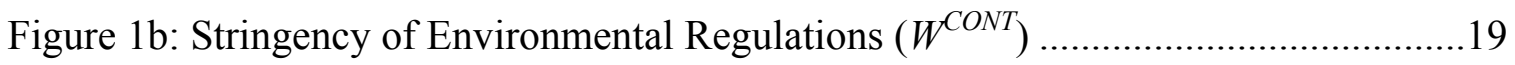

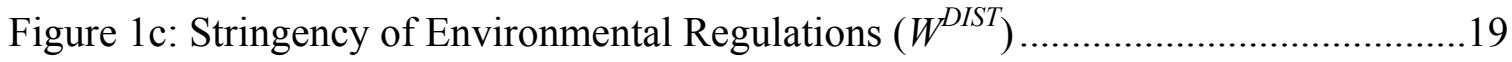

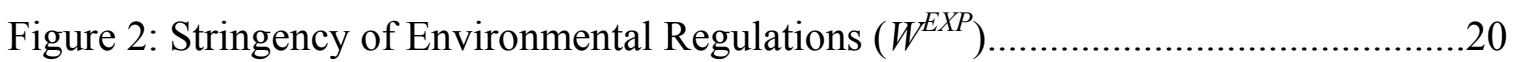

Essay 3

Figure 1: Direction of Agricultural Subsidies, United States 1985-94 ...........................86 


\section{CHAPTER 1}

\section{INTRODUCTION}

The focus of this dissertation is to analyze the impact of foreign trade, strategic behavior and political economy factors on the scope and level of domestic environmental policies. We will analyze these issues from three angles: First, what is the effect of liberalization of multilateral trade on a country's environmental regulations? Second, does the regional trade integration process induce countries to harmonize their environmental policies? Third, are polluting producers compensated for more stringent environmental policies at the national level. While these issues are frequently debated, systematic empirical evidence is still weak.

The focus of the dissertation is on environmental regulations in the agricultural sector for several reasons. First, agriculture is a politically sensitive sector in many countries. This may induce governments to behave strategically when determining domestic environmental regulations in an effort to gain a competitive position in trade. Secondly, agriculture uses immobile capital - land, which differently from the capital in manufacturing sector cannot be moved as a response to more stringent environmental regulations, reducing thus incentives for strategic behavior. However, more stringent regulations can still induce the movement of production to countries with more lax environmental regulations, increasing thus incentives for strategic behavior of economic agents. Thirdly, the agricultural sector enjoys a generally high level of government support, which in some cases may be channeled to producers as a compensation for more stringent environmental regulations.

The first paper of this dissertation titled "Does Trade Liberalization Cause a Raceto-the-Bottom in Environmental Policies? A Spatial Econometric Analysis" explores the 
impact of the openness of a country's trade regime on the determination of its environmental regulations. We find no evidence that the multilateral trade liberalization process has a negative impact on environmental regulations. The results show that:

(i) Trade openness has a positive impact on domestic environmental regulations countries with more open trade regimes tend to have also more stringent environmental regulations;

(ii) Countries with open trade policies place a significant weight on the environmental policies implemented by their trading partners that also have open trade regimes; and

(iii) Trade flows have no significant impact on countries' environmental policies - we could not find evidence that multilateral trade liberalization causes countries to act strategically when determining the scope and level of domestic environmental regulations.

However, we find that countries located in the same geographical region tend to have similar levels of environmental policies. This result provides motivation to study further whether trade influence coordination of environmental policies at the regional level where the integration process may be deeper. Cultural similarities may also play an important role here, as countries with more similar social structures and values may find it easier to cooperate on setting domestic public policies.

The second paper, titled "Regional Trade Agreements and Coordination of Environmental Regulations: Empirical Evidence", extends the analysis of trade liberalization further by studying the extent that regional economic and political integration processes influence the outcome of national environmental policies. Our 
results indicate that Regional Trade Agreements (RTAs) have mixed effects on the domestic environmental regulations:

(i) The effect of RTAs on members environmental regulations was positive among Custom Unions and regional integration processes among high-income countries (i.e., the 'North-North' integration);

(ii) The impact of RTAs on the environmental regulations was less evident or divergent among Free Trade Agreements (FTAs) and low-income countries (i.e., 'South-South' integration); and

(iii) Regional integration processes between high-income and low-income countries (the 'North-South' integration) may induce convergence of environmental regulations in low-income countries towards policies of high-income countries. The effect is especially strong when taking into account the bilateral trade flows.

The results suggest that a country's best policy response is to increase stringency of its environmental standards - countries mimic policies of block members, which may lead to positive harmonization of environmental regulations within RTAs. This may, however, take place also for strategic reasons. For example, the governments may mimic more stringent regulations of their block members in order to gain better access to their markets. Strategic geo-political and shared social values may also induce harmonization of public policies at the regional level. At the same time, governments face political pressures from domestic producers whose production costs will be increased as a result of more stringent standards.

The third paper titled "Environmental Regulations, Transfers, and Trade: Theory and Evidence", departs from strategic interaction among the countries and focuses on the political behavior of domestic lobby groups. The paper provides a theoretical model that 
shows how policy makers may compensate polluting producers with various support (subsidy and transfer) programs for their expenditures associated with environmental regulations as compensation for greater pollution taxes mitigated the effect of pollution taxes on output. Such transfers reduce the expected negative effects of environmental policies on production and trade flows and, therefore, increases the political support of policy makers. The empirical work supports the theory. More stringent environmental regulations yield greater transfers to agricultural producers, which also must affect international trade. This may explain why researchers have previously not been able to detect negative effects of environmental regulations on international trade. The results of this dissertation provide important policy implications:

- First, the results provide no support to the claim that global trade liberalization must halt or be reversed because environmental policy-making will suffer. Instead, we find that the impact of trade openness on environmental policies is positive, but it is indirect and may come through faster growth of incomes (higher demand for the environment) and reduced population growth (reduced pressures on the environment). However, the effect may be negative in the short-run. Hence, countries need to implement appropriate environmental safeguard measures, which mitigate the specific negative impacts associated with trade liberalization.

- Second, low-income countries that trade relatively more with high-income countries with strict regulations may have incentives to set themselves stricter policies as free trade gives them exposure to technologies and knowledge transfer that allows them to benefit more from environmentally friendly management 
approaches. This is an additional reason for the high income countries to trade more with developing countries.

- Third, the effect of RTAs on environmental regulations differs between the different forms of free trade agreements, as well as; along the geographical and income dimensions. A regional trade integration process has a positive impact on environmental regulations among Custom Unions while the impact of Free Trade Agreements is ambiguous. This supports the argument that regional trade liberalization efforts should include parallel appropriate environmental agreements and safeguard measures.

- Fourth, (non-reciprocal) free trade agreements between high-income and lowincome countries ('North-South' trade) have a positive impact on the convergence of environmental policies. Free trade may be a strong force to induce developing countries to upgrade their environmental policies towards those of high-income countries, especially when access to high income markets is subject to low income countries committing themselves to certain policy reforms, including improving their environmental performance;

- Fifth, compensation provided by the governments to the polluting producers tends to neutralize the effects of more stringent environmental regulations on output. This implies that environmental policy is rendered less effective by such compensating transfers while being more costly to taxpayers, since these often lead to a less than optimal reduction in production and pollution; and

- Sixth, positive harmonization of environmental policies among the trade partners is feasible as long it goes in parallel to sectoral policy reforms, including trade barriers and government assistance and transfers to producers. 
CHAPTER 2: ESSAY 1

\title{
Does Trade Liberalization Cause a Race-to-the-Bottom in Environmental Policies? A Spatial Econometric Analysis"
}

\author{
Paavo Eliste ${ }^{\mathrm{a}, \mathrm{b}}$
}

\footnotetext{
${ }^{a}$ West Virginia University, ${ }^{b}$ The World Bank

* Funding from the Swedish International Development Cooperation Agency (SIDA) is gratefully acknowledged. The opinions expressed are those of the authors and not those of Sida or the World Bank. The usual disclaimers apply.
}

Keywords: Environmental regulations, Trade Liberalization, Spatial econometrics. 


\begin{abstract}
This paper explores the impact of the openness of a country's trade regime on the determination of its environmental regulations. The empirical results suggest that trade openness has a positive impact on domestic environmental regulations - countries with more open trade regimes tend to have also more stringent environmental regulations. We find that countries seem to set more stringent environmental regulations if their close trading partners have already relatively strict regulations.
\end{abstract}




\section{INTRODUCTION}

This chapter explores the impact of openness to trade, and the size of trade flows, on the determination of environmental regulations. Some authors argue that as a result of global trade liberalization countries are likely to relax domestic environmental policy standards in order to increase (or maintain) "competitiveness" [see Esty (1994), Dua and Esty (1997), Esty and Geradin (1997)]. This could potentially lead to a "race to the bottom," where countries continually undercut the competitors' regulations, or refrain from enacting new environmental policies altogether, a "regulatory chill". Fredriksson (1999) shows in a political economy model that the effect of trade liberalization on politically determined pollution taxes depends on the size of the relative shifts in political power of producer and environmental lobby groups that occur as a result of the liberalization [see also Bommer and Schulze (1999)]. Others argue that "ecological dumping" may occur, where environmental policies are set at suboptimally lax levels for strategic reasons [Barrett (1994), Kennedy (1994), Rauscher (1994)]. Industry and union interests join the environmentalists in their fear that trade liberalization will create "Pollution Havens" with low stringency of environmental regulations and a comparative advantage in polluting sectors. These fears have given rise to calls for harmonization of environmental policies in regional free trade areas, e.g., across the EU or NAFTA members [Esty and Geradin (1997)].

There is also a growing literature on the effects of environmental regulations on the pattern of trade. Economic theory predicts that more stringent environmental regulations will result in lower exports and greater imports in polluting sectors [see, e.g., Merrifield (1988) and Copeland and Taylor (1994)]. However, the literature has found small or 
insignificant effects of environmental regulations on trade and firm location [see, e.g., Kalt (1988), Tobey (1990), and Van Beers and Van den Bergh (1997)]. ${ }^{1}$

We focus entirely on the agricultural sector. The objectives are threefold. First, do the agricultural sector environmental regulations in a country's trade partners influence the policies enacted by the country itself? If so, what is the direction of this influence? Second, do countries located in the same geographical area have similar environmental regulations? Finally, we seek to determine whether a country's openness to trade influences the stringency of the environmental regulations set in the agricultural sector. To our knowledge spatial econometric techniques have not previously been applied to these issues. Neither has the impact of international trade on the stringency of environmental regulations been explicitly analyzed empirically. Only indirect evidence exists on this issue. ${ }^{2}$ The main contribution of this chapter is the application of adequate spatial techniques to the analysis of the relationship between trade and environmental policies.

We model the spatial interdependence between countries by hypothesizing that the stringency of environmental regulations in a given country is (partially) a function of the weighted average of its trade partners' stringency of environmental regulations. We use bilateral export shares as weights. If domestic environmental policies are determined partly by what trade partners do, we expect countries that trade relatively intensively with each other to affect each other relatively more. We also hypothesize that countries which

\footnotetext{
${ }^{1}$ See Jaffe et al. (1995) for an extensive survey.

${ }^{2}$ Fredriksson and Gaston (1999) study the impact of trade openness on the speed of ratification of the 1992 United Nations Climate Change Convention, a test of the "regulatory chill" hypothesis. A few studies have focused on strategic behavior among countries when signing international environmental agreements (IEAs) [Beron et al. (1996)], and others study voluntary and non-voluntary control of sulfur and nitrogen emissions in adherence to signed IAEs [Murdoch and Sandler (1997b)]. Others have analyzed the spatial interaction among US states in the determination of public expenditures [Case et al. (1993)], the allocation of local public goods based on the median-voter model [Murdoch et al. (1993)], and property tax competition among local governments in the Boston metropolitan area [Brueckner (1998)].
} 
are geographically close, and which therefore may trade more with each other, have similar environmental policies.

We find that countries with close trade relations tend to have similar environmental policies. We also provide initial evidence that global trade liberalization may induce countries with relatively lax environmental regulations to upgrade their policies towards the levels of their trade partners with relatively stringent regulations. However, our results do not rule out entirely that a race-to-the-bottom takes place at the regional level. We demonstrate that countries with open trade policies place a considerable weight on the environmental policies implemented by their trade partners which also have open trade regimes, and that this impact is positive. Other findings include a positive impact of per capita income and environmental pressures on the stringency of environmental regulations, whereas the producer lobby has a negative effect [see also Eliste and Fredriksson (1999)].

Our findings provide some evidence of the impact of trade regimes and economic integration on the political determination of environmental regulations in the agricultural sector. Similar relationships may exist in other sectors. Grossman and Krueger (1993) report that $\mathrm{SO}_{2}$ levels are significantly lower in cities located in countries with relatively more open trade. To the extent that trade openness has similar effects on environmental regulations in both rural and urban areas, we believe that our findings provide a partial explanation for their result. However, it should be noted that agricultural production is immobile, and therefore different results may be obtained with data from sectors with a more footloose capital stock. 
The paper is organized as follows. Section 2 specifies the empirical model. Section 3 describes the data and provides a hypothesis specification. Section 4 discusses the results, and section 5 gives a conclusion and discusses the implications.

\section{MODEL SPECIFICATION}

\section{Specification of Spatial Weight Matrixes}

The agricultural sector is resource based, i.e., a large part of the capital stock (land) is immobile. Lower environmental regulations may therefore not induce capital movements, thus lowering the incentives for strategic behavior. However, we believe that market participants have incentives to act strategically and politically based on what competing foreign producers and governments do. ${ }^{3}$ We model the interdependence between countries by taking into account the stringency of environmental regulations in each country's trade partners. The relative interdependence is determined by the bilateral export flows and the geographical distance between two countries.

We expect the interdependence between two countries to increase with the intensity of trade. This, in turn, should have an impact on a country's environmental regulations, to the extent that a nation cares the most about the environmental regulations set by its closest trading partners. Thus the stringency of each trade partner's environmental regulations is weighed accordingly. Beron et al. (1996) argue that asymmetric trade flows give nations different political and economic power over each. This may determine countries' willingness to, e.g., sign an international environmental agreement (IEA). For example, suppose nation A is a country with low stringency of

${ }^{3}$ Another feature of the agricultural sector is that various trade restrictions and price support policies exacerbate market failures in many countries. The environmental effects of commodity programs are relatively well known, see Just and Bockstael (1991). 
environmental regulations. Assume also that A exports a relatively large share of its total exports to nation B which has highly stringent regulations. In this situation, we may expect nation $\mathrm{B}$ to have a relatively large economic power over nation A because nation B's government or consumers can restrict A's access to its markets. Thus, nation A may be forced to increase the stringency of its environmental regulations on the demand from nation B's producers or consumers. By constructing the weight matrix using bilateral export flows we should capture (at least part of) the structure of the economic power among countries.

The first weight matrix is thus defined based on the value of the total agricultural export flows from country $j$ to country $i, W^{E X P} .{ }^{4}$ The off-diagonal elements of the matrix, $w_{i j}$, denote the share of nation $j$ 's total agricultural exports shipped to nation $i$, $w_{i j}=\frac{E X P_{i j}}{\sum_{j} E X P_{i j}}$, where $E X P_{i j}$ denotes the value of bilateral agricultural export trade flows between nations $i$ and $j, i \neq j$.

However, a deficiency of this weight matrix is that the aggregated bilateral trade flows may not fully capture the interdependence between countries. For example, two countries located in the same geographical region that produce identical commodities may not export to each other (since they produce identical goods), but to a third country. The weight matrix based on aggregated trade flows does not incorporate this indirect form of interdependence. ${ }^{5}$ Countries located in the same geographical area (region) may

\footnotetext{
${ }^{4}$ We defined agricultural exports as food exports (S001) plus non-food agricultural exports (S002). The following countries did not report the value of their agricultural exports for 1990: Bulgaria, Czechoslovakia, Dominican Republic, Mozambique, Nigeria, South Africa, Tanzania, and Zambia. We therefore assume that the value of agricultural exports from these countries equals the value of agricultural imports from these same countries into their trade partners.

${ }^{5}$ Another problem is that only the aggregated flows are considered, the patterns explored may be different in some commodity groups.
} 
also have similar environmental regulations due to regional trade agreements that incorporate environmental considerations, e.g. through harmonization.

To account for this deficiency we define three different spatial weight matrixes based on geographical location. The first is a simple contiguity scheme where countries are defined as neighbors if they share a common border. The resulting general contiguity matrix is defined as $W^{C O N T}$. The elements of the contiguity matrix are defined as $w_{i j}=\frac{c_{i j}}{\sum_{j} c_{i j}}$, where $c_{i j}=1$ when country $i$ and $j$ share a common border, and $c_{i j}=0$ otherwise. There are 50 countries that are connected to some extent in our sample. For some island countries which do not have physical border with their neighbors, we use a specification of neighbors based on their geo-economic ties as discussed by Vamvakidis (1998).

The second measure of geographic proximity is based on the shortest great circle distance between each country. The resulting weight matrix is denoted $W^{D I S T}$. The elements of the distance weight matrix are defined as $w_{i j}=\frac{1 / d_{i j}}{1 / \sum_{j} d_{i j}}$, where $d_{i j}$ is the great circle distance between the geographical centroids of countries $i$ and $j$. The advantage of the distance matrix is that it enables the weights to capture the geographical proximity of the "island" countries.

The third distance based weight matrix is specified as a general contiguity matrix where two countries are defined as neighbors if the distance between the centroids is less than a predetermined critical value:

$$
\begin{gathered}
w_{i j}=1 \text { if } D I S T_{i j}<D I S T_{c} ; \\
\text { else } w_{i j}=0
\end{gathered}
$$


where $D I S T_{c}$ is the critical distance. To capture the possible impact of trade flows at the regional level on environmental regulations we interact this distance based contiguity matrix with the bilateral agricultural exports weight matrix. The resulting matrix is called $W_{D I S T}^{E X P}$, with off-diagonal elements defined as $w_{i j}=\frac{E X P_{i j}}{\sum_{j} E X P_{i j}}$ if $D I S T_{i j}<D I S T_{c}$; else $w_{i j}=$

0 , where $D I S T_{c}$ is the critical distance.

\section{Econometric specification}

The econometric specification models a country's stringency of environmental regulations as a function of a weighted average of all other countries' stringency of environmental regulations and the country-specific explanatory variables,

$$
s=\rho W s+X \beta+\varepsilon,
$$

where $s$ is an $n$ by 1 vector of the values of the stringency of environmental regulations, $\rho$ is a spatial autoregressive parameter, $W$ is a $n$ by $n$ spatial weight matrix, $X$ is a $n$ by $k$ matrix of the exogenous variables, $\beta$ is a $k$ by 1 vector of regression coefficients, and $\varepsilon$ is an $n$ by 1 vector of independent and identically distributed error terms, $\varepsilon \sim N\left(0, \sigma^{2} I\right)$. The elements of the weight matrix $\rho W$ specify the strength of interdependence between each pair of countries, where the stringency of environmental regulations is weighted more heavily the larger the relative trade shares or closer the countries are located to each other.

The simultaneous determination of the stringency of environmental regulations implies that the term $W_{S}$ is correlated with the error term, $\varepsilon$. Moreover, the multidimensional nature of the dependence implies that $W s$ in equation (1) is correlated 
with a vector of $\varepsilon$, which means that OLS is biased and inconsistent. We can remove the bias by solving equation (1) for the $s$ vector [ Anselin (1988)],

$$
s=(I-\rho W)^{-1} X \beta+(I-\rho W)^{-1} \varepsilon .
$$

Since expression (2) is now non-linear in parameters it can be estimated consistently using maximum likelihood (ML) techniques. Multiplying $X$ by $(I-\rho W)^{-1}$ implies that the stringency of environmental regulations in a given country depends on the country specific characteristics (the direct effect) and the characteristics of all other countries it interacts with (the indirect effect).

The spatial dependence may also enter into the regression through the error term. Given $s=X \beta+\varepsilon$ the error structure takes the following form,

$$
\varepsilon=\lambda W \varepsilon+\eta,
$$

where $\eta$ is the well-behaved error vector, $\eta \sim N\left(0, \sigma^{2} I\right), W \varepsilon$ is the spatially lagged error term, and $\lambda$ is the spatial autoregressive coefficient. The consequence of ignoring the spatial error dependence is biased standard errors.

\section{DATA DESCRIPTION AND HYPOTHESIS SPECIFICATION}

\section{The Dependent Variable}

Our measure of the stringency of environmental regulations is an index based on individual country reports on environmental regulations for the agricultural sector that were compiled for the 1992 United Nations Conference on Environment and Development in Rio [UNCED (1992)]. Based on the information gathered, an index (STRING) of the stringency of environmental regulations was first developed by Dasgupta et al. (1995) for 31 countries. Eliste and Fredriksson (1999) extended the data 
set to 62 countries using the same methodology as Dasgupta et al. We cannot detect an apparent systematic bias in this index that could drive our results. Below we discuss the independent variables expected to influence STRING.

\section{Independent Variables}

We define the spatial interaction variables, $W \_S T R I N G$, by multiplying each of the two different spatial weight matrices, $W$ (discussed above), with a vector of STRING. A negative (positive) sign of the coefficients for the resulting $W_{-}$STRING variables implies that the stringency of environmental regulations decreases (increases) as countries become more integrated via trade, or are located more closely.

The control variables include a trade openness dummy (OPENdummy) [Sachs and Warner (1995)], which takes a value of 1 for open and 0 for closed countries. Assuming that environmental quality is a normal good, the demand for environmental quality, and thus the stringency of these regulations, increases with per capita GDP (GDPpc). The producers' marginal cost of environmental regulations depends on the size of the agricultural sector. We expect a larger share of total value added from agriculture (AGDPsh) to lower STRING. Moreover, agricultural pollution has a greater negative impact on welfare if the population density (POPdensity) is high, which should result in a greater stringency of environmental regulations. The environmental pressure variables include, first, the share of agricultural land to total land area (AGLANDsh), and second, per hectare fertilizer use (FERTph). We expect both to have positive impacts on STRING [see Just and Antle (1991) and Goklany (1996)]. DEMOCRACYdummy, which takes a value of 1 when the country is free (democratic) and zero otherwise, controls for institutional factors [Freedom House (1991)]. We expect this dummy to have a positive sign. 


\section{EMPIRICAL RESULTS}

Exploratory Measures of Spatial Interdependence

First, we carry out a test for spatial autocorrelation using the Moran's I statistic [Anselin (1996)]. For a row standardized spatial weight matrix, the Moran's I statistic is the ratio of the spatial cross product to the variance, $I=\frac{\sum_{i} \sum_{j} w_{i j} x_{i} x_{j}}{\sum_{i} x_{i}{ }^{2}}$, where the $x_{i}$ 's denote the stringency of environmental regulations in country $i$ measured as the deviation from the mean, and $w_{i j}$ are the matching elements of a spatial weight matrix $W{ }^{6}$

Figures $1 \mathrm{a}-\mathrm{c}$ visualize the structure of spatial autocorrelation between the countries in the sample using the Moran scatterplot suggested by Anselin (1996). We plot the stringency of environmental regulation in country $i\left(\operatorname{STRING}_{i}\right)$ against its spatially lagged values $\left(W_{-} S T R I N G_{i}\right)$ in a standardized form. Deviations larger than two can be considered as outliers. Observations in the upper right hand quadrant of the figures indicate a positive spatial autocorrelation between high values of STRING and W_STRING, and observations in the lower left hand quadrants indicate a positive spatial autocorrelation among low values (i.e., a spatial clustering of countries with similar level of environmental stringency). A negative spatial association is shown in the upper left hand quadrant and the lower right-hand quadrant (i.e. a clustering of dissimilar values).

\footnotetext{
${ }^{6}$ All spatial weight matrixes used in the analysis are row standardized.
} 
Figure 1a: Stringency of Environmental Regulations $\left(W^{E \times P}\right)$

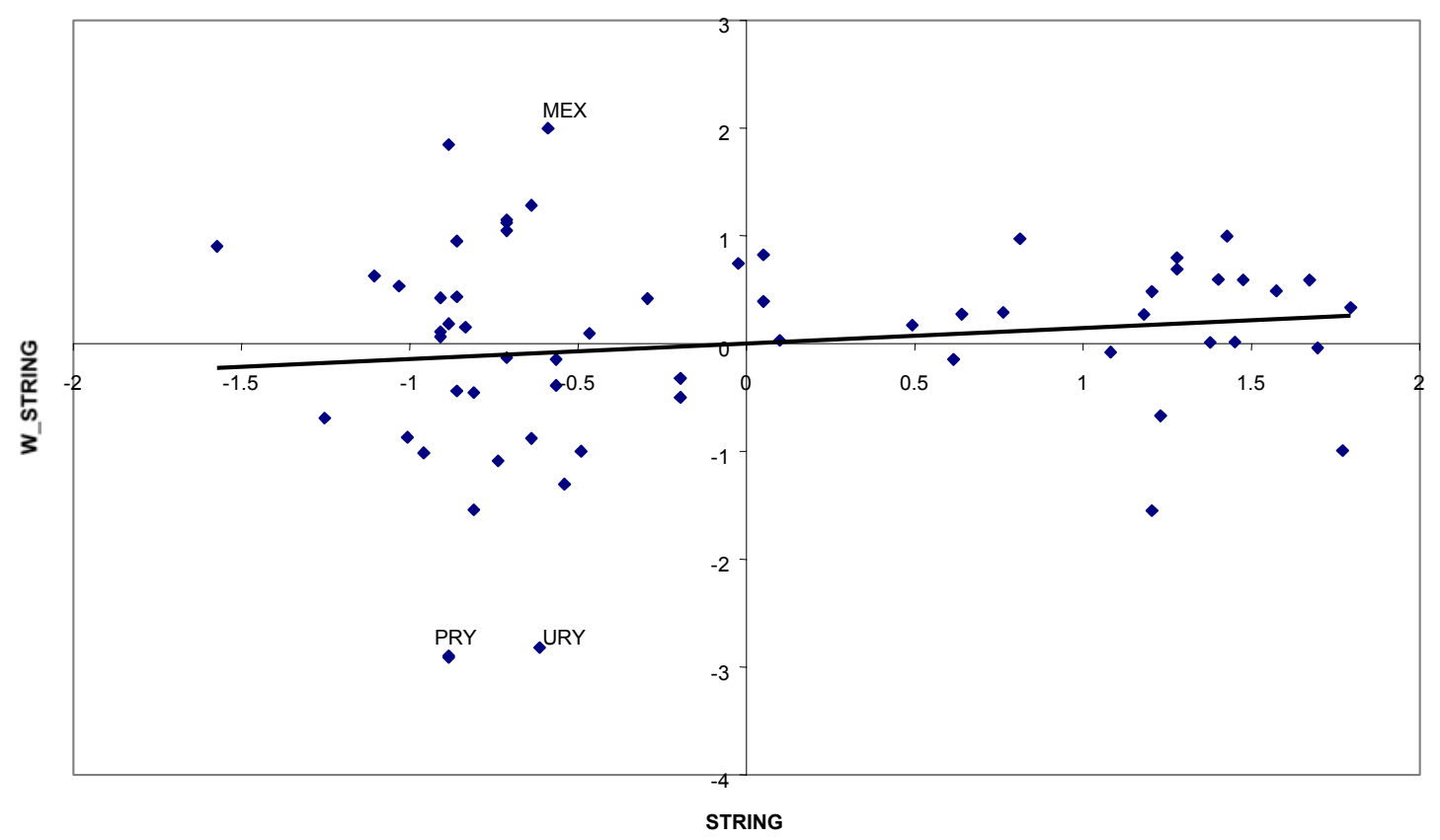

Figure 1.a indicates a weak spatial autocorrelation between STRING and the agricultural exports based weight matrix, $W^{E X P}$ (Moran's I statistic equals 0.04 at $\mathrm{p}<$ 0.19). Out of the sample of 62 countries only 18 fall into the upper right-hand quadrant. This shows a clustering of high stringency countries, i.e., countries with high measures of STRING export to other high STRING countries. At the same time, 19 low STRING countries trade equally often with high STRING countries (Mexico being one of the most extreme observations), and other low STRING countries (Uruguay and Paraguay being outliers). The lower right-hand quadrant of Figure 1.a shows high STRING countries that trade predominantly with low STRING countries. We anticipate that if race-to-the-bottom takes place, it may occur among countries located in the bottom left and bottom right quadrants of Figure 1.a. 
Figure 1b: Stringency of Environmental Regulations ( $W^{\mathrm{CONT}}$ )

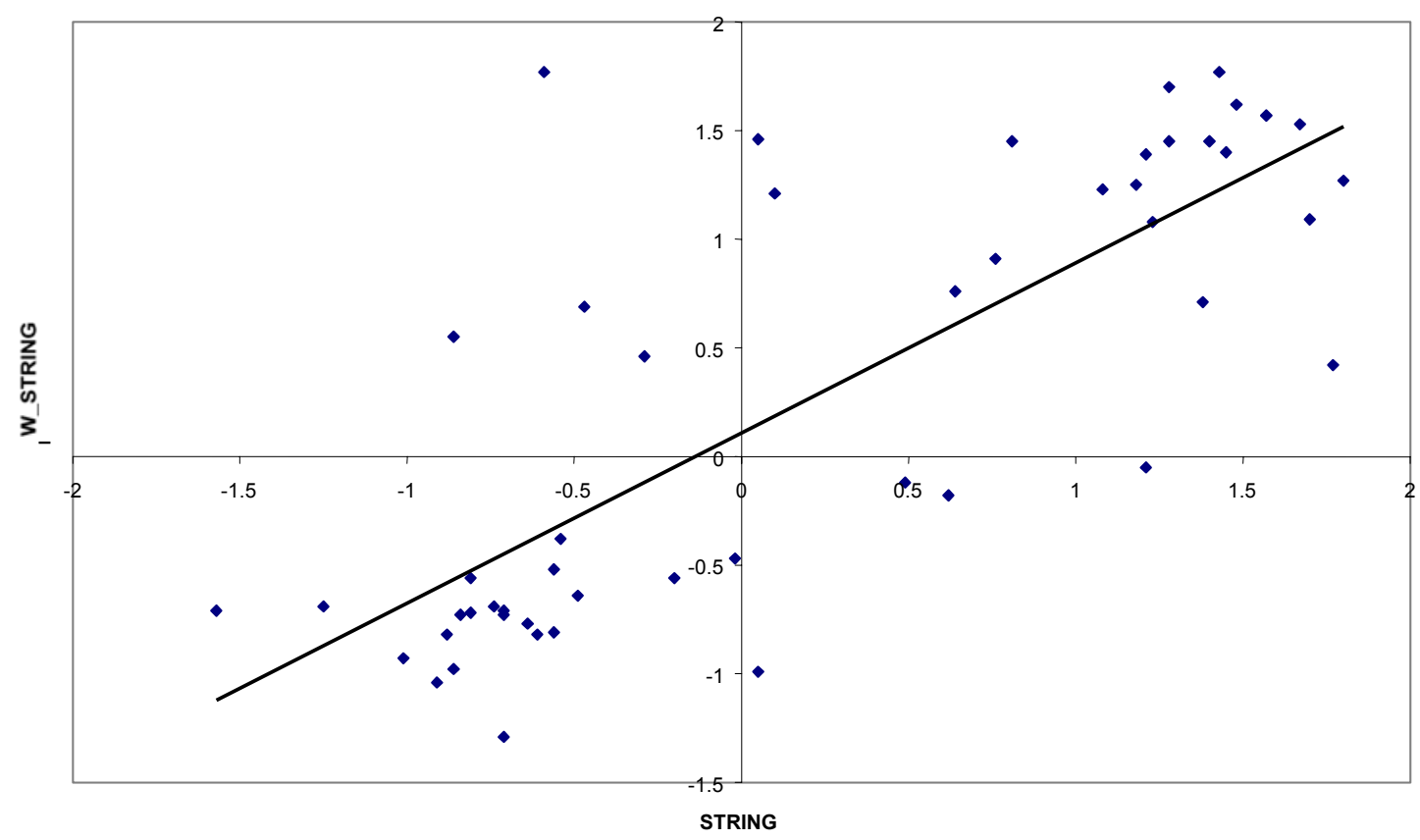

Figure 1C: Stringency of Environmental Regulations ( $\left.W^{\text {DIST }}\right)$

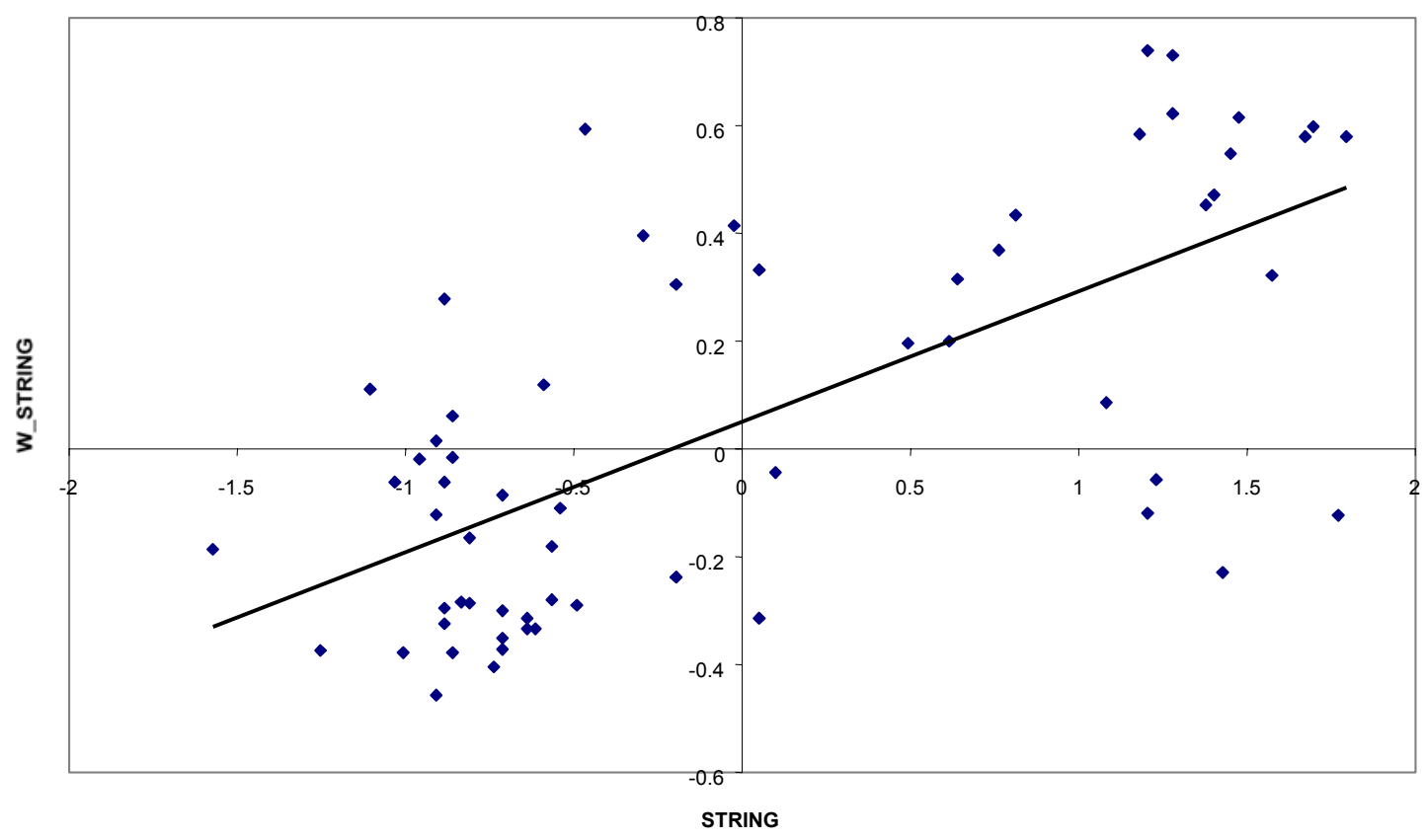


Figures 1.b and $\mathrm{c}$ plot the stringency of environmental regulations against the spatially lagged values using the geographical spatial weight matrixes $W^{C O N T}$ and $W^{D I S T}$. Moran's I statistics are now 0.85 and 0.24 for the contiguity and great circle distance based weighting schemes, respectively, which are significant at the 1 percent level. This indicates that geographical location may have an important role in determining environmental regulations. Countries located in the same geographical region tend to have similar high or low values of STRING.

Figure 2: Stringency of Environmental Regulations $\left(W^{E X P}\right)$

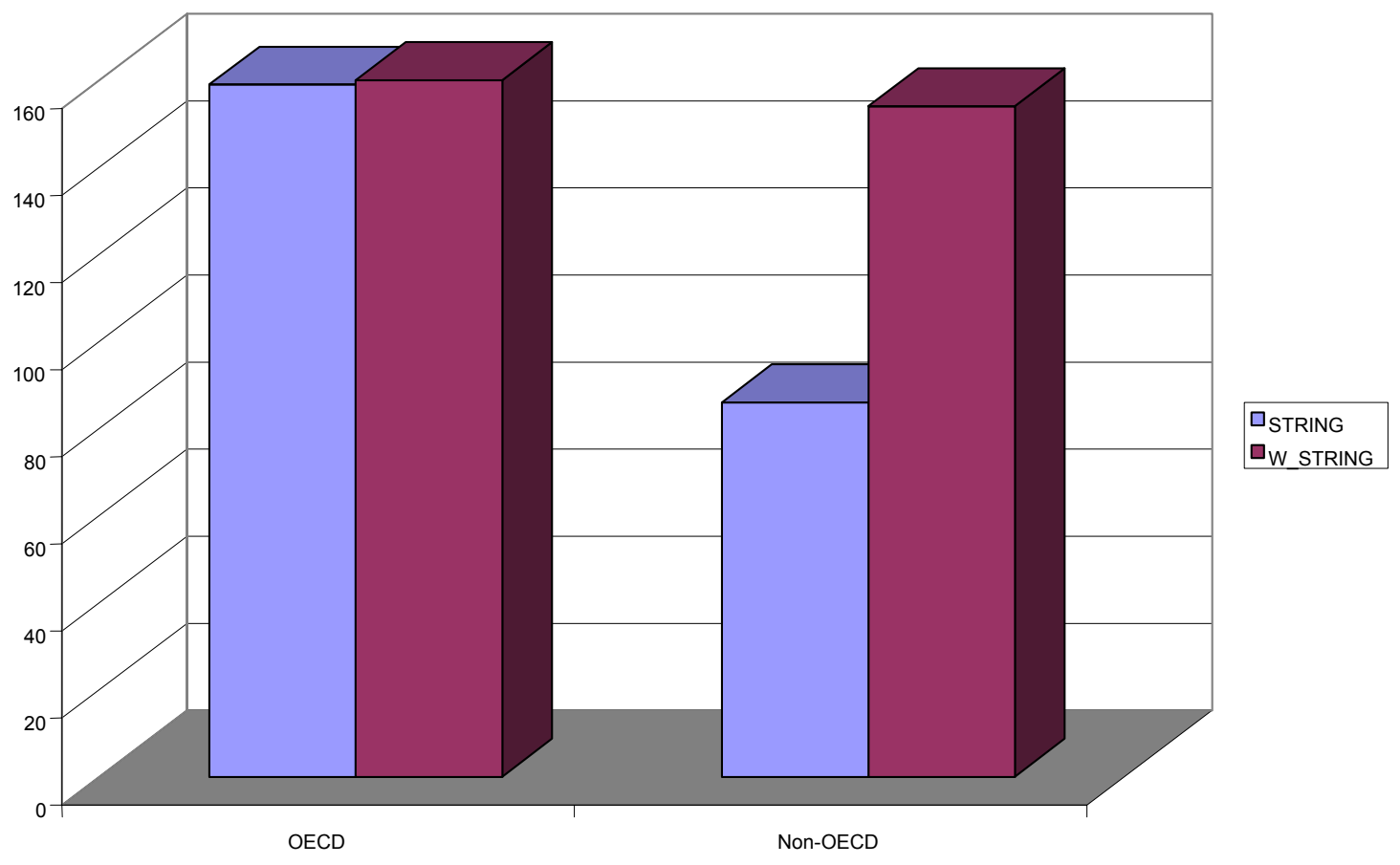

Figure 2 shows the mean values of the unweighed and agricultural-exportweighed stringency of environmental regulations for OECD (high-income) and nonOECD (low-income) countries. For OECD countries both bars are about the same height, implying that countries with stringent environmental regulations export predominantly to 
each other. The opposite is the case for non-OECD countries where the trade weighted average STRING is significantly greater than their own stringency of regulations. ${ }^{7}$

It should be noticed that our findings are here based on global measures of spatial dependence. Thus, this does not rule out the possibility that various races to the bottom take place regionally. For example, Figure 1.a indicates that there are a number of low STRING countries that export primarily to other low stringency countries. However, the main focus of the regression analysis below is to investigate the global pattern of spatial dependence.

\section{Regression Analysis}

The econometric model estimated here is specified as:

$$
\begin{gathered}
\text { STRING }_{i}=\alpha+\rho \text { WEIGHTstring }_{i}^{k}+\beta_{1} \text { GDPPc }_{i}+\beta_{2} \text { GDPsh }_{i}+\beta_{3} \text { POPdensity }_{i}+\beta_{4} \text { AGLANDsh }_{i}+ \\
\beta_{5} \text { FERTph }_{i}+\beta_{6} \text { DEMOCRACYdummy }_{i}+\beta_{7} \text { OPENdummy }_{i}+\varepsilon_{i}
\end{gathered}
$$

where $k$ designates the weight matrixes, and $\varepsilon_{i}$ is the well-behaved regression residual.

Table 1 presents the results of the cross-country estimation of the stringency of environmental regulations. The regressions were run using SpaceStat software, using a linear functional form [Anselin (1995)]. Regression 1 provides OLS estimates for comparison.

\footnotetext{
${ }^{7}$ The pattern is consistent with the findings of Aten (1997) who finds that high-income countries trade predominantly with other high-income countries, and low-income countries trade with high-income countries.
} 
Table 1: The Impact of Spatially Weighted Stringency of Environmental Regulations on Domestic Environmental Regulations $\left(\right.$ STRING) ${ }^{1,2}$.

\begin{tabular}{|c|c|c|c|c|c|c|}
\hline & \multicolumn{6}{|c|}{ Regression } \\
\hline & 1 & 2 & 3 & 4 & 5 & 6 \\
\hline \multirow[t]{2}{*}{ W_STRING } & - & 0.057 & $0.081^{* *}$ & 0.213 & $0.081^{* *}$ & - \\
\hline & & $(0.374)$ & $(2.458)$ & $(1.148)$ & $(2.458)$ & \\
\hline \multirow[t]{2}{*}{ INTERCEPT } & $76.809^{* * *}$ & $68.353^{* * *}$ & $70.832^{* * *}$ & $55.429^{* *}$ & $70.831^{* * *}$ & $77.387^{* * *}$ \\
\hline & $(8.876)$ & $(2.894)$ & $(8.686)$ & $(2.696)$ & $(8.686)$ & $(9.019)$ \\
\hline \multirow[t]{2}{*}{$G D P p c$} & $0.003^{* * *}$ & $0.003^{* * *}$ & $0.003^{* * *}$ & $0.003^{* * *}$ & $0.003^{* * *}$ & $0.003^{* * *}$ \\
\hline & $(7.362)$ & $(7.870)$ & $(7.562)$ & $(7.285)$ & $(7.562)$ & $(7.230)$ \\
\hline \multirow[t]{2}{*}{$A G D P s h$} & -0.418 & $-0.422^{*}$ & -0.312 & $-0.384^{*}$ & -0.313 & $-0.426^{*}$ \\
\hline & $(-1.652)$ & $(-1.790)$ & $(-1.360)$ & $(-1.626)$ & $(-1.360)$ & $(-1.697)$ \\
\hline \multirow[t]{2}{*}{ POPdensity } & -0.002 & -0.002 & -0.001 & -0.002 & -0.001 & -0.002 \\
\hline & $(-0.749)$ & $(-0.821)$ & $(-0.464)$ & $(0.889)$ & $(-0.463)$ & $(-0.740)$ \\
\hline \multirow[t]{2}{*}{ AGLANDsh } & $0.223^{* *}$ & $0.221^{* *}$ & $0.182^{*}$ & $0.193^{*}$ & $0.182^{*}$ & $0.219^{* *}$ \\
\hline & $(2.049)$ & $(2.171)$ & $(1.853)$ & $(1.859)$ & $(1.853)$ & $(2.009)$ \\
\hline \multirow[t]{2}{*}{ FERTph } & $0.030^{*}$ & $0.030^{*}$ & $0.026^{*}$ & 0.024 & $0.028^{*}$ & $0.030^{*}$ \\
\hline & $(1.775)$ & $(1.877)$ & $(1.681)$ & $(1.405)$ & $(1.681)$ & $(1.761)$ \\
\hline \multirow[t]{2}{*}{ DEMOCRACYdummy } & 0.312 & 0.111 & 0.056 & 0.648 & 0.054 & 0.021 \\
\hline & $(0.050)$ & $(0.019)$ & $(0.010)$ & $(0.114)$ & $(0.010)$ & $(0.003)$ \\
\hline \multirow[t]{2}{*}{ OPENdummy } & $13.600^{* *}$ & $13.652^{* *}$ & $15.407^{* * *}$ & $12.986^{* *}$ & $15.408^{* * *}$ & - \\
\hline & $(2.065)$ & $(2.214)$ & $(2.605)$ & $(2.135)$ & $(2.605)$ & \\
\hline \multirow[t]{2}{*}{ W_STRING*OPENdummy } & - & - & - & - & - & $0.088^{* *}$ \\
\hline & & & & & & $(2.070)$ \\
\hline Spatial weight matrix & - & $W^{E X P}$ & $W^{C O N T}$ & $W^{D I S T}$ & $W_{D I S T 1100}^{E X P}$ & - \\
\hline Akaike IC & 528.9 & 530.8 & 525.2 & 529.6 & 525.2 & 526.6 \\
\hline \multirow[t]{2}{*}{ Spatial BP-test $t^{3}$} & 10.62 & 10.66 & 8.95 & 11.59 & 8.95 & 10.29 \\
\hline & $(0.16)$ & $(0.15)$ & $(0.26)$ & $(0.11)$ & $(0.26)$ & $(0.11)$ \\
\hline \multirow[t]{2}{*}{ LR-test (spatial lag) ${ }^{3}$} & - & 0.13 & 5.72 & 1.28 & 5.72 & - \\
\hline & & $(0.72)$ & $(0.02)$ & $(0.26)$ & $(0.02)$ & \\
\hline \multirow[t]{2}{*}{ LR-test (spatial error) ${ }^{3}$} & - & 1.30 & 0.06 & 0.90 & 0.06 & - \\
\hline & & $(0.25)$ & $(0.80)$ & $(0.34)$ & $(0.80)$ & \\
\hline Number of Observations & 62 & 62 & 62 & 62 & 62 & 62 \\
\hline
\end{tabular}

\footnotetext{
${ }_{2 * * *}^{1}$ Asymptotic $\mathrm{z}$-values in parenthesis

${ }^{* * *} \mathrm{p}<0.01,{ }^{* *} \mathrm{p}<0.05,{ }^{*} \mathrm{p}<0.10$

3 . Probability values in parenthesis
} 
Regressions 2 to 5 in Table 1 present maximum likelihood estimates for the spatial lag model. ${ }^{8}$ The coefficient for the spatial lag term $W_{-} S T R I N G$ is positive but insignificant when using the agricultural export spatial weight matrix, $W^{E X P}$. The positive coefficient indicates that the likelihood of a given country adopting more stringent environmental regulations is higher if its trade partners have adopted stricter regulations. However, the impact is small. A 1 percent increase in the stringency of a trade partner's environmental regulations increases a country's stringency of environmental regulations by only 0.1 percent.

The positive coefficient for the spatial lag variable based on the geographical weighting scheme (regressions 3 and 4) indicate that countries located in the same geographical region tend to set similar environmental policies. The spatial lag coefficient ( $W_{-}$STRING) with the general contiguity based weight matrix $\left(W^{C O N T}\right)$ is significant at the 1 percent level. It may also reflect the fact that neighboring countries tend to have similar agro-climatic conditions and therefore similar production structures. Therefore, they may have similar environmental problems as well as policies. However, the magnitude of the coefficient for the spatial lag variable using the great circle distance $\left(W^{D I S T}\right)$ is more than twice as great as the coefficient for the contiguity based matrix. A given country's stringency of regulations increases by 0.2 percent when the neighboring countries' stringency increases by 1 percent. However, the coefficient is statistically insignificant.

Next we estimated the spatial lag model using agricultural export flows only among neighboring countries $\left(W_{D I S T}^{E X P}\right)$. We examined 11 different distance bands ranging

\footnotetext{
${ }^{8}$ Alternative model specifications included semilog, log-log, and linear-log functional forms. The best model fit was achieved with linear functional form.
} 
from 500 to $1,500 \mathrm{~km}$. The robust Lagrange Multiplier (LM) test was used to search for the appropriate model specification. The best fitting models resulted at critical distance values of 1,000 and $1,100 \mathrm{~km}$. The robust LM tests for $1,000 \mathrm{~km}$ and $1,100 \mathrm{~km}$ equal 4.73 and 4.99 , respectively, which both imply $\mathrm{p}<0.03$. Regression 5 in Table 1 presents the results using a critical distance value at $1,100 \mathrm{~km}\left(W_{D I S T 1,100}^{E X P}\right)$. The coefficient for $W_{-}$STRING is significant at 5 percent level. This suggests that regional trade arrangements may have a strong impact on the determination of environmental regulations. For example, regional trade may lead to harmonization of environmental regulations among close trading partners.

According to the Akaike Information Criterion (AIC) the best fit was obtained with the general contiguity matrix $\left(W^{C O N T}\right)$ and the matrix using export flows among countries located within the same geographical area $\left(W_{D I S T 1,100}^{E X P}\right)$. The spatial BreuschPagan (BP) test does not indicate the presence of heteroscedasticity in any of the models. The Likelihood Ratio (LR) test for spatial lag dependence confirms the appropriateness of the spatial lag specification. Moreover, the test for spatial error dependence does not indicate the presence of non-spherical errors, suggesting a good model specification.

The results for the control variables are largely as expected. GDPpc is significant at the 1 percent level in all models. $A G D P s h$ has the expected negative sign, and is significant at the 10 percent level in models 2 and 4. POPdensity is negative but insignificant. Turning to the environmental pressure variables, both $A G L A N D s h$ and FERTph have the expected positive signs and are statistically significant at least at the 10 percent level in most models. DEMOCRACYdummy is positive but insignificant, whereas OPENdummy is significant at least at the 5 percent level. We interpret the latter result as follows. Countries with more open trade regimes tend to have more stringent environmental 
regulations. First, more open economies grow faster and thus create a greater surplus that can be used for environmental protection. Second, greater openness may also give a greater exposure to novel ideas such as the benefits of environmental policies. Third, reputational concerns may also play a role, in particular for exporters. Consumer groups in foreign countries may demand products with lower pesticide residue, etc. Both exporters and import competitors have an interest in reduced costs, however, and this would tend to put downward pressure on environmental policies. The latter effect does not appear to be important in our data, relatively seen. Finally, greater trade openness induces diffusion of new production technologies, which in addition to higher technical efficiency also may be environmentally more efficient. ${ }^{9}$

Next we turn to the question whether more open countries take into account the environmental regulations of their trade partners in a different way than do relatively closed countries. We interacted OPENdummy with the trade weighted $\left(W^{E X P}\right)$ spatial lag variable of the stringency of environmental regulations, $W_{-}$STRING. If countries with open trade policies are more receptive to the level of their trade partners' environmental regulations than relatively closed countries, then trade liberalization by high STRING countries may have a positive impact on environmental policies and quality. Since $W_{-}$STRING is correlated with the error term we estimated the model using a two-stageleast-squares estimator (2SLS). ${ }^{10}$ Regression 6 in Table 1 shows that the interaction term $W_{-} S T R I N G^{*} O P E N$ is positive and significant at the 5 percent level. Countries with open trade policies take their trade partners environmental policies into account to a greater degree when determining the scope and level of their environmental polices. The

\footnotetext{
${ }^{9}$ Reinhard et al. (1997) report a positive relationship between technical efficiency and environmental efficiency in Dutch dairy farms.

${ }^{10}$ The instruments used are all right-hand side variables in model 6.
} 
environmental regulations set in an open country then partially depend on the regulations set by the open country's trade partners. If these are open this effect should tend to encourage more strict regulations since our earlier regressions show that open countries have greater levels of STRING. On the other hand, an open country that opts to reduce the strictness of its regulations may induce a race to the bottom with other countries with liberal trade regimes.

In sum, we find evidence that trade openness has a positive impact on the level of environmental regulations in the agricultural sector. The intuition behind this finding may be that countries that trade with high STRING countries may gain a better understanding of the benefits of environmental regulations. This effect is stronger the closer are the trade partners geographically. Moreover, the asymmetric trade interdependence between countries implies that high STRING countries may be able to (directly or indirectly) force countries with lax regulations to increase the stringency of their standards. For example, importing nations may impose food safety standards and sanitary rules on agricultural exporters, and thereby influence exporters to adopt stricter regulations. Eco-labeling schemes are also used for, e.g., coffee, bananas, and sugarcane, although this phenomenon was small in the year 1990 when our data was collected.

\section{CONCLUDING COMMENTS}

This paper tested the hypothesis that trade liberalization induces a race to the bottom in the political determination of environmental regulations in the agricultural sector. Moreover, we explored the hypothesis that neighbors and trade partners influence environmental policies. A novel contribution of the study is the finding that countries do not set their environmental regulations independently. The results of the spatial lag model 
suggest that countries set more stringent environmental regulations if their close trading partners have relatively strict regulations. There also appears to be a positive relationship between the stringency of environmental regulations and trade openness. We interpret this as the effect of trade liberalization creating greater economic growth and therefore a greater economic surplus available to use for environmental protection. Moreover, reputational effects, increased technology transfers, and a greater exchange of ideas about environmental regulations may play a role.

These findings have policy implications. We cannot find support for the claim that global trade liberalization must halt because environmental policies will suffer. Developing countries that trade relatively heavily with countries with strict regulations have themselves stricter policies. Instead there may be an additional reason for OECD countries to increase the stringency of their environmental regulations, and to trade more with developing countries, rather than less. Moreover, the next Round of trade liberalization talks may set of a chain of events in the area of environmental policy.

More research is needed on these questions, however. The agricultural sector may be a special case because of particularly heavy government intervention distorting prices. Moreover, stricter food safety standards and sanitary measures may be induced by strong consumer demand for less polluting products and production. Moreover, this sector is resource based with immobile capital (land). Thus, lower environmental regulations do not induce firm relocation and capital movements, although the pattern of production and trade should be affected in the long run. The incentive to lower environmental standards may be much greater if this induces an inflow of new and additional capital investments. At the same time, there are NIMBY (Not in My Back Yard) considerations, where environmental policies may be used to discourage local investments in polluting sectors. 
Spatial econometric techniques would be even more appropriate for the analysis of sectors with mobile capital stocks.

It should also be emphasized that we are not able to infer whether the level and scope of the regulations observed are optimal. We can only explain the variation between countries. Moreover, our results do not imply that environmental quality necessarily must improve with more open trade since scale, composition, and technique effects are also present [see Grossman and Krueger (1993)]. 


\section{REFERENCES}

Anselin, L (1996), Interactive Techniques and Exploratory Spatial Data Analysis. RRI Working Paper, West Virginia University.

Anselin, L. (1995), SpaceStat Version 1.80. User's Guide. Regional Research Institute, West Virginia University.

Anselin, L. (1988), Spatial Econometrics: Methods and Models. Kluwer Academic Publishers.

Anselin, L. and A.K. Bera. (1998), "Spatial Dependence in Linear Regression Models with an Introduction to Spatial Econometrics," in A.Ullah and D.Giles (eds.), Handbook of Applied Economic Statistics, New York:Marcel Dekker.

Aten, B.H. (1997), "Does Space Matter? International Comparisons of the Prices of Tradables and Nontradables," International Regional Science Review, 20(1), pp. $35-52$.

Barrett, S. (1994), "Strategic Environmental Policy and International Trade," Journal of Public Economics 54(3), pp. 325-38.

Beron K.J., J.C. Murdoch, and W.P.M. Vijverberg (1996), "Why Cooperate? An Independent Probit Model of Network Correlations," Working Paper, School of Social Sciences, University of Texas at Dallas.

Bommer, R. and G.G. Schulze (1999), "Trade Liberalization and Environmental Policy as Distributional Substitutes: Why the North American Free Trade Agreement Improves the Environment," forthcoming, European Journal of Political Economy.

Brueckner, J.K. (1998), Testing for Strategic Interaction Among Local Governments: The Case of Growth Controls. Journal of Urban Economics 44, pp. 438-67.

Case, A.C., H.S.Rosen, and J.R.Hines (1993), "Budget Spillovers and Fiscal Policy Interdependence," Journal of Public Economics 52, pp. 285-307.

Copeland, B.R. and M.S. Taylor (1994), "North-South Trade and the Environment," Quarterly Journal of Economics, August, pp. 755-87.

Dasgupta, S., A. Mody, S. Roy, and D. Wheeler (1995), "Environmental Regulation and Development. A Cross-Country Empirical Analysis," Policy Research Working Paper \# 1448, Policy Research Department, World Bank.

Dua, A. and D.C. Esty (1997), Sustaining the Asia Pacific Miracle, Washington, DC: Institute for International Economics.

Esty, D.C. (1994), Greening the GATT: Trade, Environment, and the Future, Washington, DC: Institute for International Economics.

Esty, D.C.and D. Geradin (1997), "Market Access, Competitiveness, and Harmonization: Environmental Protection in Regional Trade Agreements," The Harvard Environmental Law Review 21(2), pp. 265-336.

Eliste, P. and P.G. Fredriksson (1999), "The Political Economy of Environmental Regulations, Government Assistance, and Foreign Trade," Ch. 9 in Trade, Global 
Policy, and the Environment, edited by P.G. Fredriksson, World Bank Discussion Paper \#402, Washington DC: The World Bank.

Fredriksson, P.G. (1997), "The Political Economy of Pollution Taxes in a Small Open Economy," Journal of Environmental Economics and Management 33(1), pp. 4458.

Fredriksson, P.G. (1999), "The Political Economy of Trade Liberalization and Environmental Policy," Southern Economic Journal 65(3), pp. 513-25.

Fredriksson, P.G. and N. Gaston (1999), "The Importance of Trade for the Ratification of the 1992 Climate Change Convention," Ch. 12 in Trade, Global Policy, and the Environment, edited by P.G. Fredriksson, World Bank Discussion Paper \#402, Washington DC: The World Bank.

Gastil, R.D. (1987), Freedom in the World, Westport, Conn.: Greenwood.

Goklany, I.H. (1996), "Factors Affecting Environmental Impacts: The Effect of Technology on Long-term Trends in Cropland, Air Pollution, and Water Related Diseases," Ambio 25(8), pp. 497-503.

Grossman, G.M. and A.B. Krueger (1993), "Environmental Impacts of a North American Free Trade Agreement," in The U.S.-Mexico Free Trade Agreement, edited by P. Garber, Cambridge, MA: MIT Press.

Just, R.E. and J.H. Antle (1991), "Effects of Commodity Program Structure on Resource use and the Environment," in Commodity and Resource Policies in Agricultural Systems, eds., Berlin and New York: Springer-Verlag.

Just, R. E. and N. Bockstael (editors). (1991). Commodity and Resource Policies in Agricultural Systems, , Berlin and New York: Springer-Verlag.

Kalt, J.P. (1988), “The Impact of Domestic Environmental Regulatory Policies on U.S. International Competitiveness," in International Competitiveness, edited by A.M. Spence and H.A. Hazard, Cambridge, MA: Harper and Row, Ballinger.

Kennedy, P.W. (1994), "Equilibrium Pollution Taxes in Open Economies with Imperfect Competition," Journal of Environmental Economics and Management 27, pp. 4963.

Kiefer, N. and M. Salmon (1983), "Testing Normality in Econometric Models," Economics Letters 11, pp. 123-28.

Low, Patrick and Alexander Yeats (1992), "Do 'Dirty' Industries Migrate?," in International Trade and the Environment, edited by P. Low, World Bank Discussion Paper \#159, Washington, DC: World Bank.

Lucas, R. E. B., D. Wheeler, and H. Hettige (1992), "Economic Development, Environmental Regulation and Pollution and the International Migration of Toxic Industrial Pollution: 1960-88," in International Trade and the Environment, edited by P. Low, World Bank Discussion Paper \# 159, Washington, DC: World Bank.

Merrifield, J.D. (1988), "The Impact of Selected Abatement Strategies on Transnational Pollution, the Terms of Trade, and Factor Rewards: A General Equilibrium 
Approach,"Journal of Environmental Economics and Management 15, pp. 25984.

Murdoch, J.C., M. Rahmatian, and M.A. Thayer (1993), "A Spatially Autoregressive Median Voter Model of Recreational Expenditures," Public Finance Quarterly, 21(3), pp. 334-350

Murdoch, J.C. and T. Sandler (1997a), "The Voluntary Provision of a Pure Public Good: The Case of Reduced CFC Emissions and the Montreal Protocol," Journal of Public Economics 63, pp. 331-49.

Murdoch, J.C. and T. Sandler (1997b),"A Tale of Two Collectives: Sulfur Versus Nitrogen Oxides Emission in Europe," Economica 64, pp. 281-301.

Rauscher, M. (1994), "On Ecological Dumping," Oxford Economic Papers 46(5), pp. $822-40$.

Reinhard, S., C.A. Knox Lovell, and G. Thijssen (1997), "Econometric Estimation of Technical and Environmental Efficiency: An Application of Dutch Dairy Farms," Mimeo, Agricultural Economics Research Institute, The Hague.

Sachs, J.D. and A. Warner (1995), "Economic Reform and the Process of Global Integration," Brookings Papers on Economic Activity 26(1), pp. 1-118.

Scully, G.W. (1992), Constitutional Environments and Economic Growth, Princeton, NJ: Princeton University Press.

Summers, R. and A. Heston (1989), "The Penn World Tables (Mark 5): An Expanded Set of International Comparisons, 1950-1988," Quarterly Journal of Economics 106, pp. 327-69.

Tobey, J.A. (1990), "The Effects of Domestic Environmental Policies on Patterns of World Trade: An Empirical Test," Kyklos 43, pp. 191-209.

UNCED (1992), Nations of the Earth Report, Vol. I-III, Geneva: United Nations.

Vamvakidis, A. (1998), "Regional Integration and Economic Growth," The World Bank Economic Review 12(2), pp. 251-70.

Van Beers, C. and J.C.J.M. Van den Bergh (1997), "An Empirical Multi-Country Analysis of the Impact of Environmental Policy on Foreign Trade Flows," Kyklos 50(1), pp. 29-46. 
CHAPTER 3: ESSAY 2

\title{
Regional Trade Agreements and Coordination of Environmental Regulations: Empirical Evidence
}

\author{
Paavo Eliste ${ }^{\mathrm{a}}$
}

a The World Bank, West Virginia University

Keywords: Environmental regulations, Regional Trade Agreements, Strategic behavior, Spatial econometrics 


\begin{abstract}
This paper analyses the impact of regional economic and political integration process on the scope and level of domestic environmental policies. We use spatial econometrics techniques to study the evidence of strategic behavior among countries induced by regional integration process. The results indicate that Regional Trade Agreements (RTAs) induce positive harmonization of environmental regulations among the members of custom unions and free trade agreements among high income countries. The impact of regional trade integration process was less evident or divergent among the members of Free Trade Agreements and low-income countries. However, integration processes between high-income and low-income countries may induce convergence of environmental regulations in low-income countries towards policies of high-income countries. Contrary to widely believed arguments, free trade may be indeed a powerful force to induce developing countries to upgrade their environmental policies towards those of high income countries.
\end{abstract}




\section{INTRODUCTION}

In recent years more countries have attempted to liberalize their trade and investment regimes. Increasing trade and factor movements between countries have, however, triggered calls to coordinate their commercial and public policies to the extent that such policy measures undertaken by one country may spill-over and affect negatively those of other nations [Robson (1998)]. Most of these spillovers are regional in the sense that they affect the closest neighbors most. Environmental pollution, degradation of common natural resources and ecosystems, movements of capital and labor, tax policies are for example cases where substantial jurisdictional spillovers typically arise at the regional level. Spillovers, however, can be also global in their nature (carbon emissions, degradation of biodiversity), which means that policy coordination to internalize these effects may extend beyond the strict geographic notion of the region. The inability of multilateral trading agreements to address these and other public policy issues of among its large and diverse group of contracting parties has thus become one of the driving forces for regional integration process. The later has gradually expanded beyond free trade arrangements, with political, environmental, social and cultural aspects taking a prominent role [see Hettne (1998), Anderson (1996)].

The impact of regional integration processes on environmental policies has been widely discussed among scholars and policymakers. It has been argued that participation in Regional Trade Agreements (RTAs) can push block member's environmental policies in either direction, with winners and losers trying to influence the outcome through strategically setting their national policies and standards to improve their competitive position [Anderson (1996)]. Specifically, there is a fear that RTAs among countries with

different levels of environmental standards (and incomes) may force countries with more 
stringent regulations to lower their environmental standards below levels what they would adopt in isolation for strategic reasons in an effort to gain a competitive position in trade [Barret (1994), Kennedy (1994), Rausher (1994), Li (1999), Nordhaus (1994)]. This has lead to calls to narrow gaps between environmental regulations (i.e. compliance costs) in high standard and low standards members of the RTAs, in order to reduce pressures on environmental standards, and internalize spillover effects associated with free trade [Esty and Geradin (1997)].

Despite of these fears, few empirical studies have yet analyzed the effect of economic integration and trade liberalization on trade block members' environmental regulations. Eliste and Fredriksson [forthcoming] study the impact of multilateral trade liberalization on countries' environmental regulations. They find that countries with more open trade regimes have more stringent environmental regulations. The multilateral trade flows, on the other hand, do not have a significant impact on countries' environmental regulations. This indicates a lack of strategic behavior among the countries when setting their domestic environmental policy levels. However, the study finds that trade may influence coordination of environmental policies at the regional level - countries located in the same geographical region tend to also have more similar level of environmental policies. This suggest that harmonization of environmental policies may take place at the regional level where interaction between the countries is stronger.

This paper will attempt to bring the issue of trade liberalization and public policy reforms further by analyzing to what extent does the regional economic and political integration process influence the scope and level of national environmental policies and regulations? To our knowledge the impact of regional trading arrangements on environmental regulations of member countries has not been analyzed explicitly. We 
will argue that regional economic integration among countries, fostered by RTAs may enable trade-based regional groups to internalize the policy spillover effects among members of the trade blocks through closer coordination of their environmental regulations. First, we are interested in whether countries interact with each other in setting their domestic environmental policies. Second, does the strength (intensity) of interaction vary across different forms of RTAs?

We expect the incentives to coordinate the level of domestic environmental policies to increase the more advanced are the integration process. We examine the effect of various forms of RTAs (i.e. custom unions, free trade areas) along different geographical dimensions of the regional integration process (i.e. North-North, South-South, and NorthSouth) on the scope and level of domestic environmental regulations using agricultural sector as an example.

Our findings provide some new evidence on the impact of regional trade arrangements and subsequent economic and political integration on the determination of domestic environmental regulations of member countries in the agricultural sector. Our results indicate that RTAs have mixed effects on the environmental regulations. The effect of RTAs on members' environmental regulations is positive among Custom Unions (CUs) and RTAs that include high-income countries ('North-North' integration). The impact of regional trade integration on environmental regulations is less evident among Free Trade Areas (FTAs). RTAs, which include only low-income countries may on the other hand induce divergence in their environmental policies, with some countries choosing to reduce the stringency of environmental standards. We also found that free trade agreements between high income (high stringency) and low-income (low stringency) countries ('North-South' integration) may have a positive impact on 
environmental standards. The effect is especially strong when we take into account the bilateral trade flows between countries.

The paper is organized as follows. Section 2 discusses synergies between regional free trade arrangements and regional environmental cooperation agreements among the member countries. Section 3 specifies the empirical model and describes the data. Section 4 discusses the empirical results, and section 5 gives a conclusion and discusses the policy implications.

\section{REGIONAL TRADE AGREEMENTS AND ENVIRONMENTAL POLICY HARMONIZATION}

Several regional trade arrangements have made an effort to incorporate environmental measures directly into RTA agendas as early as in 1970 s and 80 s. This is quite intuitive as countries located in the same geographical region often share common ecosystems and natural resources, which may me subject to negative (positive) spillovers from neighboring countries (i.e. pollution, allocation of water resources, movement of wildlife, etc.). As such, members of RTAs may have strong incentives to internalize some of these spillovers. For example, the Convention Establishing the Latin American Economic System (SELA) of 1975 includes the goal of cooperating 'for protection, conservation and improvement of the environment'. ASEAN first took up the issue of regional environmental cooperation in 1981 when it approved the Manila Declaration. In the Singapore summit of 1992 the members of this FTA agreed to work towards harmonized environmental quality standards [Charnovitz (1995)]. 
Several international environmental agreements also overlap with free trade agreements at the regional level. For example, the ASEAN Agreement on the Conservation of Nature and Natural Resources (1985) requires members of the trade block to adopt by themselves, or where necessary and appropriate through coordinated action, the measures necessary to maintain essential ecological processes and life-support systems, to preserve genetic diversity, and to ensure the sustainable utilization of harvested natural resources under their jurisdiction [Charnovitz (1995)]. The EU provides a common market among the member nations and also pursues regional environmental objectives (i.e. protection of the environment and human health and rational use of natural resources) through its Single European Act (1987). Several subregional environmental cooperation agreements exist between individual EU members, which have direct relevance to agriculture and natural resources management, such as Benelux Convention on Nature Conservation and Landscape protection (1983). Sweden, Norway, Finland (members of EFTA) and Denmark (EU) coordinate their environmental cooperation through Nordic Environmental Protection Convention (1976). A number of member countries of RTAs in Africa are also signatories of African Convention of Nature and Natural Resources (1969), which requires the signatory parties to ensure the conservation and sustainable utilization of biodiversity and natural resources. While the effectiveness of these arrangements has in general been rather weak, the efforts to coordinate environmental policies have been relatively more successful in RTAs where the integration process has been deeper (i.e. Single European Act).

Regional integration process may take various forms depending on specific political and economic goals of member countries. Social objectives may also have a prominent role in the dynamics of particular integration process. Among most common 
types of RTAs are Customs Unions (CUs), Free Trade Areas (FTAs), Preferential Trade Agreements (PTAs), common markets, and economic unions. While the common feature of all RTAs is the reciprocal nature of the preferential treatment of members of the trade block, differences exist among specific commercial arrangements. Typically CUs and common markets entail more political integration among member countries than FTAs. First, CUs may entail supra-national bodies to negotiate the common external tariff (CET) and revenue sharing mechanisms, which is not the case for FTAs. Second, CUs are often pursued by countries which aim to attain some common political objectives, including the creation of regional public goods, such as security or democracy [Schiff (2000) and Isidro and Winters (1999)]. As such, some CUs have evolved into common markets over time, which may includes a deeper forms of integration, such as free movement of factors or harmonization of regulations and standards. Example of this is European Union, which in addition to liberalization of trade among its members is also pursuing common public policies, including the environment. This may not be the case with FTAs where economic integration process has been focused mainly on trade liberalization [Isidro and Winters (1999)].

The objectives of regional integration process and distribution of benefits among members of RTAs may differ also according to their income levels. Venables (1999) argues that RTAs between developing countries (i.e. 'South-South' integration) lead to divergence of income levels, with members with factor endowments closer to the rest of the world benefiting at the expense of those whose factor endowments are more different from the rest of the world. The welfare losses result thus from trade diversion, provided that there are no compensatory transfers in place between the members of the RTA. However, RTAs that contain high income members ('North - North' dimension) are 
more likely to lead convergence of their income levels, with lower incomes countries with factor endowment closer to the rest of the world growing faster than higher income (extreme endowment) members. If the demand for environmental quality increases with income levels, we expect that RTAs formed by high-income countries ('North-North' integration) may thus have more incentives to harmonize their environmental regulations as achieving common agreements is easier the more similar are the per capita incomes, tastes and preferences [Anderson (1996)].

In the case of 'North-South' trade agreement, Venables (1999) shows that all members from RTA benefit from liberalizing trade. Countries now move towards production of the good intensive in the factor which they are abundantly endowed. This factor abundance is now relative to each other and relative to the rest of the world, and it is this what cerates the mutual benefits - low income countries are likely to be better served by 'North-South' than by 'South-South' free trade agreements. This result is supported by empirical evidence. For example, Ben-David (1993) offers evidence that after signing RTAs, the EU, the EFTA, and the Canada-US Free Trade Agreement displayed marked increases in trade between member countries and dramatic increases in income convergence. This convergence may be upward, with poor members growing faster than wealthier members (Ben-David 1994). Vamvakidis (1998) examines the impact of five RTAs - ASEAN, Andean Pact, CACM, UDEAC, and EU - on the economic growth rate of its members. He concludes that 'South-South' agreements among small, and generally closed developing countries are unlikely to have a positive impact on growth, while agreements along 'North South' dimension are more likely to have positive growth effect on southern partner. 
The benefits from 'North-South' trade arrangements may extend beyond the efficiency gains. For example, a RTA may promote technology transfer from the high income country to lower income members via its effect on trade, which may contribute to economic growth [Coe and Helpman (1995), Coe, Helpman and Hoffmaister (1997), Sjoholm (1996)]. A likely source of technology transfer is foreign direct investments, which are another important incentive for countries to form and participate in RTAs [Schiff and Winters (1998)]. Fingelton (1998) shows that technological spill-over effects via 'North-South' trade embodying foreign knowledge causes faster growth and hence 'catch-up' by low-income countries through gaining access to higher technological standards of high income countries, which reduces need for investments into R\&D. Regional trade involving low income and low technology countries, on the other hand, gives them less incentive to increase their domestic technological standards as domestic companies in the trading block are shield from imports from high technology countries.

Several North-South free trade agreements exist. Some of them grant equal access to members markets (i.e. NAFTA), while others give selected low income countries a preferential (in some cases non-reciprocal) access to the markets of high income countries. For example, the EU has concluded a large number of trade agreements with many developing countries, either individually or as a group. Virtually all Northern African, Middle Eastern and Mediterranean countries have now some kind of bilateral agreement with the EU. The Lome' Convention provides developing countries in Africa, Caribbean, and Pacific region a non-reciprocal access to EU markets. Other 'NorthSouth' RTAs include trade agreements between United States and Canada and various Latin and Central America and Caribean low income countries; and preferential free trade 
agreement between Australia and New Zealand and developing countries in the South Pacific Region. The products covered under these agreements include almost all agricultural and industrial exports, with only a few exceptions. The primary objective of these trading arrangements has been promotion of economic development in the beneficiary (mainly low income) countries by means of improved trade performance. For example, preferential trade agreements with high-income countries have helped beneficiary low income countries to diversify away from traditional raw materials exports into higher value manufacturing (industrial) products, which has contributed to economic growth in those countries [Onguglo (1999)].

The common feature of preferential trade schemes between high and low income countries (especially non-reciprocal) is that the block members have to meet certain conditions, often social or political, to be eligible for trade access and to maintain their beneficiary status. The contractual nature of these agreements implies that low-income members countries are often a weaker side in trade negotiations. A high income importing countries may thus use free trade agreements with low income exporting countries as an enforcement mechanism to lock in certain economic reforms and public policies in low-income countries. For example, NAFTA agreement between the low income Mexico and high income USA and Canada included a set of environmental safeguard measures which put pressure on the low income member to improve its environmental performance. 


\section{EMPIRICAL IMPLEMENTATION}

We focus on the impact of regional integration process on the environmental regulations in the agricultural sector. We argue that countries do not set their domestic environmental policies independently, but rather as a response to a level of standards set by other block members ${ }^{11}$. Countries may choose to lower their environmental standards in the pursuit to gain competitive position or seek to mimic each other environmental for strategic reasons $^{12}$. In this framework, a country $i$, which belongs to a given RTA $k$ chooses the level of domestic environmental standards $s_{i}$ as a function of its characteristics $X_{i}$ and the level of environmental standards set by its block members, $s_{-i k}$. We can express country $i$ 's objective function as

$$
U\left(s_{i k}, s_{-i k} ; X_{i}\right)
$$

where $s_{-i k}$ is the vector of members' stringency of the environmental standards in a RTA $k$, and $X_{i}$ is a vector of country specific characteristics, such as income level, relative resource endowment, and political pressure from producers and environmentalists lobby groups. A country $i k$ maximizes its welfare by choosing the optimal level of $s_{i}$

$$
s_{i}=V\left(s_{-i k} ; X_{i}\right)
$$

The equation (2) constitutes a policy reaction function, which gives a country $i$ 's best response to the choices of environmental standards set by the members of a RTA [see Brueckner (1998) and Saavedra (2000)]. The slope of the policy reaction function, may be either positive or negative, depending on the properties of the vector of second order partial derivatives. We interpret this as an existence of interaction among the

\footnotetext{
11 See Brueckner (2001) and Brueckner (2000) for the overview and discussion of strategic interactions models.

${ }^{12}$ See Heyndels and Prucha (1998) and Besley and Case (19952) for mimicking of tax policies among jurisdictions.
} 
countries in setting their domestic environmental standards. A zero slope of the reaction function indicates, on the other hand that countries set their environmental standards independently of the level of standards set by other bloc members.

Equation (2) tells us nothing about the optimality of domestic environmental standards, $s_{i}$ from the social point of view. All the slope of the policy reaction curve tells us is whether the interaction between the countries leads to mimicking (i.e. harmonization) or divergence of environmental standards among the members of the trade block. Race-to-the-bottom may thus still take place where countries set their standards at sub-optimally low level for strategic reasons, even if the slope of the reaction function is upwards. We discuss the specification of the strategic interaction among the members of a RTA in next section.

We specify the structure of interaction among the block members using the spatial weigh matrixes, $W^{13}$. The off-diagonal elements of the weight matrix, $w_{i j k}$, are defined as 1 when the countries $i$ and $j$ belong to the same trading block (RTA), and zero otherwise (see the Annex for the sample weigh matrix). The stringency of environmental regulations in a country $i, s_{i}$, is thus a function of weighted sum of the stringency of environmental regulations in all other countries in a given trade block $k, \sum_{j} w_{i j} s_{i}$, where $w_{i j}$ is the $j$-th row element of the weight matrix and $i=1, \ldots, n$.

\footnotetext{
${ }^{13}$ The multidimensional nature of interdependence between the countries within the trade block implies that the estimation of the interaction parameters of the $n$ by $n$ dimensional covariance matrix becomes unfeasible because of incidental parameter problem, i.e. a number of interaction parameters to be estimated increased at the faster pace then sample size. In order for the problem to become tractable, we must explicitly specify the elements of the spatial weight matrix $W$, so that a finite number of parameters characterizing the interactions between the countries can be efficiently estimated [see Anselin and Bera (1998)].
} 


\section{Econometric Specification}

The econometric specification of the problem models a country's stringency of environmental regulations as a function of a weighted average of other RTA members stringency of environmental regulations and a country specific explanatory variables,

$$
s_{i}=\rho W s_{i}+X_{i} \beta+\varepsilon_{i}
$$

where $s$ is $n$ by 1 vector of stringency of environmental regulations, $W$ is the spatial weight matrix $W, X$ is an $n$ by $k$ matrix of exogenous variables, $\varepsilon$ is an $n$ by 1 vector of independent and identically distributed error terms, $\varepsilon \sim N\left(0, \sigma^{2} I\right)$, and $\beta$ is a $k$ by 1 vector of regression coefficients.

Anselin (1988) refers to Equation (3) as a spatial lag model and $\rho$ as a spatial autoregressive parameter. The weight matrix $W$ aggregates the vector of $s$ in $j$ countries interacting with $i$ country into a spatial lag variable. We expect the spatial lag variable Ws to capture the impact of RTAs on the stringency of environmental regulations of its member country $i$. The elements of the weight matrix $\rho W$ specify the strength and direction of interaction between the members of a trade block.

Equation (3) cannot be estimated consistently with ordinary least squares, since the errors are correlated with the right-hand-side dependent variables. We can remove this simultaneity by solving equation (1) for the $s$ vector [see Anselin (1988)],

$$
s=(I-\rho W)^{-1} X \beta+(I-\rho W)^{-1} \varepsilon .
$$

Equation (4) which now incorporates the potential correlation among errors of all members of the trade block is non-linear function of exogenous variables $X$. If state $i$ 's level of stringency of environmental regulations belong in (4), but are ignored, state $i$ 's 
right-hand-side variables, $X_{i}$, are correlated with state $i$ 's errors, leading to inconsistent estimates of $\beta$. We will estimate equation (4) consistently using maximum likelihood (ML) techniques.

Spatial Interaction Among the Members of the Trade Block

We specify spatial structure of interaction among the countries based on trade agreements notified to GATT, which were formed in 1970s and 80s using the data presented in Jovanovic, (1998) Annex $1^{14}$. We expect incentives for interactions to increase the more advanced is the economic and political integration process in the trade block or the more similar are the block members in their characteristics.

We will first differentiate between CUs and FTAs. We specify a spatial weight matrix that incorporates only the members of custom unions and common markets $\left(W^{C U}\right)$. The following major CUs are included: ANCOM, CARICOM, COMESA, ECOWAS, and EU . The second weight matrix is based on FTAs $\left(W^{F T A}\right)$ and it includes the members of : ANZCERT, CUSFTA, EFTA, LAIA, and SAARC (see Table A.1 in the Annex) In both cases, we expect the convergence of environmental policies among the members of a regional trade block, to the extent that nations seek to equalize their production costs. However, we hypothesize that the impact of regional integration arrangements on domestic environmental policies is stronger among the CUs than FTAs. We expect the former to induce closer cooperation among the members in setting their domestic economic and public policies.

\footnotetext{
${ }^{14}$ This is also the time period of evolving environmental regulations captured by our measure of environmental policies, although development of environmental policies may have been faster in highincome countries (OECD) compared to low income countries.
} 
Our specification of spatial weigh matrices is based on the assumption that regional integration process is exogenous to the domestic environmental policy levels of block members. It can be, however, argued that the formation of RTAs is itself endogenous to policy variables set by countries. While this may be the case for some factors such as FDI flows or military security, we believe that there is no evidence that formation of RTAs may have been induced by environmental policy spillovers, in particular for RTAs covered in our analysis.

Next, we specify spatial weight matrixes along the similarities of income levels of the members of the RTAs. The first weight matrix $\left(W^{N N}\right)$ combines the RTAs formed by high income countries along the so called the 'North-North' geographical dimension. The RTAs represented in the weight matrix include: ANZCERT, CUSTFTA, EU, and EFTA. The second weight matrix includes low income RTAs, which we see as economic integration along the 'South-South' dimension $\left(W^{S S}\right)$ : ANCOM, CARICOM, COMESA, ECOWAS, LAIA, and SAARC. We expect that the incentives for interaction in setting environmental policies are stronger among the high-income members of RTAs, while the impact may be weaker among low income countries.

We specify a spatial weight matrix $\left(W^{N S}\right)$ that incorporates the preferential free trade arrangements between United States and Canada and various Latin and Central America and Caribean low income countries as defined through ARPA, CBI and CARIBCAN agreements; EU member states and developing countries in Africa, Caribbean, and Pacific (ACP) countries (i.e. Third Lome Convention) and cooperation agreements with Egypt, Jordan, Morocco, and Tunisia; and preferential free trade agreement between Australia and New Zealand and countries in the South Pacific Region (SPARTECA). We hypothesize that through its positive impact on economic growth 
'North-South' RTAs promote convergence of income levels, and thus willingness of low income countries to (faster) upgrade their environmental (public) policies towards the levels of their high-income trade partners.

The specification of spatial interdependence so far is based on assumption that the structure of interaction among the block members is symmetric - countries have an equal weight on each other environmental policies. This may not be the case in reality, where the specific structure of interaction may be partly determined by asymmetry of trade flows. The magnitude of the RTAs effect on a country's environmental policies is thus determined by the relative political and economic power trade gives for countries over each other [Beron et al. (1996)].

In order to capture the asymmetry in block members' interaction, we specify spatial interdependence using the bilateral export shares between countries [see O'Loughlin and Anselin (1996)]. The off-diagonal elements of the weight matrix $\left(W^{E X P}\right), w_{i j}$, are computed as: $w_{i j}=\frac{x_{i j}}{m_{j}}$, where $x_{i j}$ denotes the share of nation $j$ 's total agricultural exports shipped to nation $i$ and $m_{j}$ are total imports of agricultural products of $j^{15}$. We specify trade interdependence among block members by interacting spatial weight matrixes of $\operatorname{RTAs}\left(W^{C U}, W^{F T A}, W^{N N}, W^{S S}\right.$, and $\left.W^{N S}\right)$ with the matrix of bilateral export flows $W^{E X P}$.

We expect interaction between individual countries to increase with the intensity of bi-lateral trade flows. The positive (negative) coefficient for the policy reaction variable indicates that the likelihood of a country to adopt a more stringent environmental

\footnotetext{
${ }^{15}$ We define agricultural exports as food exports (S001) plus non-food agricultural exports (S002). The following countries did not report the value of their agricultural exports for 1990: Bulgaria, Czechoslovakia, Dominican Republic, Mozambique, Nigeria, South Africa, Tanzania, and Zambia. We therefore assume that the value of agricultural exports from these countries equals the value of agricultural imports from these same countries into their trade partners.
} 
standards increases if their close trade partners have already high standards in place, while negative coefficient indicates that countries choose to reduce their environmental standards as a response to higher standards set by their trade partners.

\section{Data Description}

Our measure of the stringency of environmental regulations is an index based on individual country reports on environmental regulations for the agricultural sector that were compiled for the 1992 United Nations Conference on Environment and Development in Rio [UNCED (1992)]. An index (STRING) of the stringency of environmental regulations was first developed by Dasgupta et al. (1995) for 31 countries. Eliste and Fredriksson (2002) extended the data set to 62 countries using the same methodology as Dasgupta et al.

The computed index is agricultural sector specific. Most industrialized countries do have environmental programs towards agriculture in place. For example nearly all industrialized countries require extensive testing and evaluation of new pesticide products before they can be licensed for sale; they also have food safety standards in place; and they all have research and extension programs, that in many cases, encourage more environmentally and economically benign (efficient) production practices. Several Environmental and Health Safety (EHS) regulations in agricultural area have been designed to protect consumers from unsafe food; the environment from contamination; and plants and animals from disease. However, less developed countries with lower per capita income levels have reacted more slowly to environmental problems associated 
with agricultural production ${ }^{16}$. The demand for environmental quality is understandably lower in these countries. Therefore, assuming that environmental quality is a normal good, the demand for environmental quality, and thus the stringency of these regulations, increases with income levels. We use per capita GDP (GDPpc) and expect this coefficient to have a positive sign.

Economic growth causes both positive and negative effects on the environment. By extending production and consumption, growth directly causes environmental degradation through increased pollution emissions, depletion of natural resources or degradation of natural habitats [see Glover (1999) for a survey]. On the other hand, there is an indirect growth effect which alleviates environmental pressure. First, economic growth increases personal income, which results in increased demand for environmental quality. The rising demand for environmental quality improvements forces governments to establish more stringent environmental policies. Hence, environmental policy may be endogenous not only to the income level of population, but to growth as well. There are several anecdotal evidence where rapid economic growth has led also to stricter environmental regulations (i.e. Mexico, China). Second important environmental effect of economic growth comes through declining population growth. Population growth is one of the major causes of environmental degradation. Population growth rates tend to generally decline with increased income levels expands, mitigating thus pressures on the environment [Bommer and Schulze (1999) and Baldwin (1995)]. We use average annual

\footnotetext{
16 Tobey (1991) reports that although environmental regulations are indeed more stringent in developed countries (i.e. USA), they also account for a major share of pollution-intensive crop production (i.e. tobacco, peanuts, corn, sorghum, soybeans), out of which only tobacco has higher than 30 percent market share for developing countries. Hence, it is also that one expects most (more stringent) environmental regulations also to target.
} 
growth of per capita GNP over the period of 1980 to 1990 to estimate the effect of economic growth on the environment. Thus we expect the coefficient for PCGNPgrowth to take a positive sign.

Other explanatory variables include the measure of trade intensity as a proxy for trade openness, TRADEintensity, which is calculated as a ratio or agricultural exports plus imports to agricultural GDP in the year 1990 [Summers and Heston (1989)]. We will use the share of agricultural producers of the total labor force as a proxy for the political power of the farmer lobby group $(A G L A B O R s h)$. To capture the effect of institutional factors we use index of freedom of civil rights, $D E M O C R A C Y$, which is an integer with 1 (6) representing the most (least) secure rights [Freedom House (1991)]. The index measures the extent to which people are able to express their opinion openly without fears of reprisals and are protected in doing so by judiciary institutions.

Our main focus, however, is on variable for economic integration among the members of RTAs. We define the policy reaction variable, $W$ STRING, by multiplying each of the $k$ spatial weight matrices $W$, with a vector of STRING. A statistically significant coefficient for the resulting variable indicates the presence of strategic interaction among the members of trade block when setting their domestic environmental standards. The positive coefficient implies that the county $i$ rises its environmental standards as a response to higher standards of the block members. Thus, the environmental policy decision variables of the interacting governments represent "strategic complements" which may lead to mimicking (or harmonization) of each others' policies [Brueckner (2001)]. The negative coefficient of the interaction term, however, indicates that a country will lower its standards, as a response to increase of 
environmental standards of block members. The policy decision variables are thus

"strategic substitutes" which leads to divergence of environmental standards within RTA.

Using variables described above, the spatial lag model was specified as,

$$
\operatorname{STRING}_{i}=\alpha+\rho \text { WEIGHTstring }{ }_{i}^{k}+\beta_{1} \text { GDPpc }_{i}+\beta_{2} \text { GNPgrowth }_{i}+\beta_{3} \text { TRADE int ensity }_{i}+
$$

$$
\beta_{4} A_{G L A B O R S h_{i i}}+\beta_{5} \text { DEMOCRACY }+\varepsilon_{i}
$$

\section{RESULTS}

Maximum Likelihood (ML) estimates of the parameters in equation (5) are shown in Table $1-3$. The adjusted coefficient of determination (adj. $R^{2}$ ) ranges from 0.85 to 0.89 , which indicates a good fit of the linear specification ${ }^{17}$. The Likelihood Ratio (LR) test for spatial error dependence confirms the appropriateness of the spatial lag model specification. Furthermore, the test for spatial error dependence does not indicate the presence of non-spherical errors in most cases, suggesting a good model specification ${ }^{18}$. The spatial error dependence seems to be present for interactions based on FTAs.

\footnotetext{
${ }^{17}$ Multicollinearity is often a possibility in aggregated country level data. The estimated condition index is 9.54, which is significantly below the conservative threshold level of 20. Given these considerations, we do not expect multicollinearity to have detrimental effect on our results. The implementation of ML techniques requires that residuals follow the normal distribution. We use the Jarque - Bera test for normality of errors. The Chi sq test statistic is $4.14(\mathrm{p}<0.12)$, which indicates we can safely interpret the tests of statistical inference, which assume normality of errors. The spatial Breuch-Pagan test does not indicate the presence of heteroscedasticity in any of the models.

${ }^{18}$ The spatial dependence may also enter into the regression through the error term in the form of $\varepsilon=\lambda W \varepsilon+\eta$, where $\eta$ is the well-behaved error vector, $\eta \sim N\left(0, \sigma^{2} I\right), W \varepsilon$ is the spatially lagged error term, and $\lambda$ is the spatial autoregressive coefficient. The consequence of ignoring the spatial error dependence is biased standard errors, which affects hypothesis tests.
} 
Table 1: Maximum Likelihood Estimates of RTAs

\begin{tabular}{|c|c|c|c|c|c|c|c|}
\hline & \multicolumn{7}{|c|}{ Regression } \\
\hline & 1 & 2 & 3 & 4 & 5 & 6 & 7 \\
\hline \multirow[t]{2}{*}{$\overline{W \_S T R I N G}$} & $0.0812 * *$ & -0.017 & $0.205^{* * *}$ & $-0.124 * *$ & 0.014 & - & - \\
\hline & $(2.237)$ & $(-0.429)$ & $(4.814)$ & $(-2.087)$ & $(0.385)$ & & \\
\hline \multirow[t]{2}{*}{ INTERCEPT } & $92.230 * * *$ & $94.999 * * *$ & $89.965 * * *$ & $100.433 * * *$ & $93.446^{* * *}$ & $90.793 * * *$ & $94.823 * * *$ \\
\hline & (12.639) & (11.793) & $(13.995)$ & $(12.461)$ & (12.354) & (11.504) & (11.193) \\
\hline \multirow[t]{2}{*}{$G D P p c$} & $0.004 * * *$ & $0.004 * * *$ & $0.002 * * *$ & $0.003 * * *$ & $0.004 * * *$ & $0.004 * * *$ & $0.004 * * *$ \\
\hline & (9.437) & $(8.683)$ & (4.710) & (8.302) & (9.167) & (8.739) & (4.094) \\
\hline \multirow[t]{2}{*}{ ALABORsh } & $-0.344 * * *$ & $-0.320 * *$ & $-0.343 * * *$ & $-0.291 * *$ & $-0.325 * * *$ & $-0.303 * *$ & $-0.312 * *$ \\
\hline & $(-2.835)$ & $(-2.545)$ & $(-3.214)$ & $(-2.384)$ & $(-2.561)$ & $(-2.316)$ & $(-2.298)$ \\
\hline \multirow[t]{2}{*}{ GNPgrowth } & $3.385 * * *$ & $2.962 * * *$ & $2.847 * * *$ & $2.207 * *$ & $3.195 * * *$ & $2.485 * *$ & $2.874 * *$ \\
\hline & (3.203) & $(2.721)$ & (3.095) & (1.972) & $(2.729)$ & $(2.180)$ & (2.369) \\
\hline \multirow[t]{2}{*}{ DEMOCRACY } & -0.044 & -0.366 & 1.319 & -0.543 & -0.385 & 0.622 & -0.447 \\
\hline & $(-0.021)$ & $(-0.168)$ & $(0.709)$ & $(-0.259)$ & $(-0.176)$ & $(0.275)$ & $(-0.188)$ \\
\hline \multirow[t]{2}{*}{ TRADEintensity } & 0.780 & 2.624 & 1.187 & 2.760 & 2.778 & -2.232 & 1.992 \\
\hline & $(0.408)$ & (1.328) & $(0.769)$ & (1.604) & (1.498) & $(-0.894)$ & $(0.633)$ \\
\hline \multirow[t]{2}{*}{$W_{-} G D P p c^{C U}$} & - & - & - & - & - & $0.003 * * *$ & - \\
\hline & & & & & & (3.109) & \\
\hline \multirow[t]{2}{*}{$W_{-} G D P p c^{C U}$} & - & - & - & - & - & - & -0.0005 \\
\hline & & & & & & & $(-0.398)$ \\
\hline Spatial weight matrix & $W^{C U}$ & $W^{F T A}$ & $W^{N N}$ & $W^{S S}$ & $W^{N S}$ & - & - \\
\hline$R 2$ & 0.86 & 0.85 & 0.89 & 0.86 & 0.85 & 0.86 & 0.85 \\
\hline \multirow[t]{2}{*}{ Spatial BP-test } & 9.03 & 7.60 & $12.33 * *$ & 5.89 & 7.03 & - & - \\
\hline & $(0.11)$ & $(0.18)$ & $(0.03)$ & $(0.32)$ & $(0.22)$ & & \\
\hline \multirow[t]{2}{*}{ LR-test (spatial lag) } & $4.76^{* *}$ & 0.18 & $20.00 * * *$ & $3.97 * *$ & 0.16 & - & - \\
\hline & $(0.03)$ & $(0.67)$ & $(0.00)$ & $(0.05)$ & $(0.69)$ & & \\
\hline \multirow[t]{2}{*}{ LR-test (spatial error) } & 0.23 & $3.55^{*}$ & 0.20 & 0.52 & $3.36^{*}$ & - & - \\
\hline & $(0.63)$ & $(0.06)$ & $(0.65)$ & $(0.47)$ & $(0.07)$ & & \\
\hline Number of obs. & 62 & 62 & 62 & 62 & 62 & 62 & 62 \\
\hline
\end{tabular}




\section{The Effect of RTAs on the Stringency of Environmental Regulations}

Particularly important for our purposes is the effect of spatial lag coefficient ( $\left.W \_S T R I N G\right)$ on the level of domestic environmental policies. As expected, participation in CUs induces stronger interaction of environmental regulations among member countries. The coefficient for $W_{-} S T R I N G^{C U}$ is positive and statistically significant at the 5 percent level (Model 1), which indicates that the best response to a given country is to adopt more stringent environmental policies increases as a response to more stringent standards set by other block members - i.e. participation in CU may induce countries with lower standards to increase the stringency of environmental regulations towards the standards of high stringency countries. The spatial interaction term for FTAs is statistically insignificant. This suggests lack of interaction among the members in setting stringency of their domestic environmental policies.

Our results do suggest that the push for harmonization of environmental policies is stronger in CUs than in FTAs, where policy coordination among the members is confined mainly to tariff policy and product markets. This is because CUs may seek more than liberalization of trade, especially trade blocks that evolve towards common market or economic union (i.e. EU), and may thus establish common rules and standards, as well as institutions, to ensure fair distribution of benefits from free trade among member nations.

Models 3 and 4 in Table 1 present a spatial lag model using the 'North-North' and 'South-South' specification of RTAs. The coefficient for the policy reaction variable along the 'North-North' dimension is positive and statistically significant at the 1 percent level. This suggests mimicking of environmental policies among high-income countries of RTAs - countries react by setting their policies according to what other block members 
do. The correlation in members environmental policies suggest that the ultimate effect of a one percent increase in members' environmental standards is, ceteris paribus, to increase a country $i$ 's standards by 0.4 percent.

The spatial interaction term for 'South-South' RTAs, $W_{-} S T R I N G^{S S}$, is on the other hand negative and statistically significant, which indicates strong divergence in block members' environmental policy - a country would reduce its environmental standards as a response to more stringent standards set by the block members. This finding is consistent with our hypothesis, as we expect high-income countries to include public policies more often in free trade agreements, as their demand for public goods and social services is more income elastic than in low income countries who are more concerned with satisfying basic needs. Second, low income countries who form the RTA may compete on the same export markets, which is often the case with agricultural products, thus putting downward pressure on their environmental standards. Further, RTAs among low-income countries may not include transfers to compensate for welfare losses arising from trade diversion. Model 5 presents the free trade arrangement along the 'NorthSouth' dimension of RTAs. The coefficient for spatial interaction term based on $W^{N S}$ is positive but statistically insignificant, suggesting lack of interaction among block members on setting environmental policies.

It should be noted that the positive coefficient for the policy reaction variable does not say whether interaction among the countries would lead to harmonization of environmental policies under RTA. However, we are interested whether countries, which form RTAs have similar environmental process, which may be itself the outcome of harmonization process. We use Moran's I statistics to test the presence of spatial clustering of similar environmental policies among the block members [Anselin (1996)]. 
The Moran's I statistics was positive and statistically significant at 1 percent level for CUs, FTAs, 'North-North' and 'South-South' regional integration process, which indicates strong similarity of environmental policies among block members (both high and low values). The statistics was, however, negative and significant for RTAs along the 'North-South' dimension, indicating large differences in block members' environmental policies (i.e. lack of harmonization) ${ }^{19}$. Comparing these results with coefficients of policy reaction variables in Table 1 we argue that (positive) harmonization may take place in CUs and along 'North-North' dimension of regional integration, while race-to-the bottom (downward harmonization) seems to take place in RTAs along the 'South-South' dimension.

The results of the left hand side control variables are largely as expected. The coefficient for GDPpc has the expected positive sign and it is statistically significant at the 1 percent level in all models. The positive coefficient for GNPgrowth enforces the argument that countries with a relatively high annual per capita growth rate have also higher stringency of environmental regulations. This may indicate the structural switch of fast growing countries from primary sectors to manufacturing, which reduce the producers' marginal cost of environmental regulations as the size of agricultural sector declines. The latter may reduce the producers' political pressure to lower environmental standards.

The coefficient for TRADEintensity has a positive sign, which indicates that countries with more open (intensive) agricultural trade tend to have more stringent environmental regulations. However, the coefficient is statistically insignificant in all

\footnotetext{
${ }^{19}$ The values of Moran's I test statistics were $0.97,1.09,1.51,0.67$ and -0.96 respectively for $W^{C U}, W^{F T A}$, $W^{N N}, W^{S S}$ and $W^{N S}$.
} 
models. This may be caused partly by scale effects. Scully and Slottje (1991) argue that some large countries tend to trade relatively little (i.e. the United States), and much trade in the European Union is intra-union. This is supported by [Anderson and Northeim (1993)], who point out that transport costs are likely to favor domestic producers over their foreign competitors for a wider range of products in large countries than in physically smaller countries.

The significant negative coefficient for $A G L A B O R s h$ indicates that a greater number of agricultural producers puts downward pressure on environmental regulations through greater lobbying pressure and (in democracies) voting power (see Potters and Sloof (1996) for a survey). This implies that the marginal increase in the stringency of environmental regulations has a greater marginal impact on farmer aggregate welfare as their numbers increase relative to total labor force, making governments more reluctant to implement costly environmental regulations. The effect of civil rights is ambiguous. The coefficient for $D E M O C R A C Y$ has a negative sign in most cases but it is statistically insignificant.

The TRADEintensity and GNPgrowth may, however, be endogenous to trade openness and macroeconomic and sectoral policies, as well as factor endowment variables, which act as exogenous variables in our model (i.e. AGLABORsh). We use the Durbin-Wu-Hausman test to determine whether the coefficient estimates of these variables are affected by possible presence of endogeneity. We are not able to reject the null hypothesis of exogeneity of these variables. The F-test statistics for GNPgrowth and TRADEintensity are $0.21(\mathrm{p}<0.649)$ and $2.75(\mathrm{p}<0.103)$ respectively. 
The stringency of environmental policies of a given block members may not be a function of its own income levels, but also income levels of its close trading partners in the RTA. The welfare enhancing effect of regional free trade arrangements may spill over into improved environmental performance of a given country as a result of increases of its block members' income levels. Regressions 6 and 7 in Table 2 estimate the impact of a trade block members per capita GDP on a given country's environmental regulations. The trade bloc members impact is estimated by adding the spatial lag variable for per capita GDP in CUs and FTAs into the model. To avoid possible endogeneity bias, the models were estimated using the two stage least squares estimator (TSLS).

The coefficient for spatial lag term for custom unions, $W_{-} G D P p c^{C U}$, is positive and highly significant. We interpret this as an indirect impact of members of a $\mathrm{CU}$ on a given country's stringency of environmental regulations - a one percent increase of trade block member's per capita GDP increases a given country's stringency of environmental regulations by 0.14 percent, while the same increase of its own per capita GDP increases its stringency by 0.22 percent. The indirect impact of a trade block's members' income in FTAs, on the other hand, is close to zero. This finding suggests RTAs where integration process is deeper (i.e. CUs) the increase in average block income levels have strong spillover effect on block members' environmental regulations. The latter may come through transfer payments, technical assistance and knowledge sharing process. This, however, does not seem to be case in more narrowly defined RTAs, such as FTAs. 
The Effect of Bilateral Trade Flows on Environmental Regulations

Eliste and Fredriksson (forthcoming) find that multilateral trade flows have no significant effect on the determination of the scope and level of domestic environmental policies. In this section we will test whether bilateral trade flows have stronger impact at the regional level. The results of the regression in Table 2 show that while trade between countries has a positive impact on block members' environmental regulations the impact is weak (models 1 and 2). The coefficients of the spatial interaction terms $W_{-} S T R I N G^{C U_{-} E X P}$ and $W_{-} S T R I N G^{\text {FTA_EXP }}$ are both positive but statistically insignificant there may be other factors than trade which influence the interaction of environmental policies within RTAs, such as social objectives, provision of public goods, etc. Geographic proximity, openness of economic policies, production systems may be other examples. Cultural similarities may also play an important role, as countries with more similar social structures and values may find it easier to cooperate on setting domestic public policies. 
Table 2. Maximum Likelihood Estimates of Bilateral Trade Effects

\begin{tabular}{|c|c|c|c|c|c|}
\hline & \multicolumn{5}{|c|}{ Regression } \\
\hline & 1 & 2 & 3 & 4 & 5 \\
\hline \multirow{2}{*}{$W_{-}$STRING } & 0.064 & 0.062 & $0.126^{* *}$ & $-0.320 * *$ & $0.119 * *$ \\
\hline & $(1.280)$ & $(0.716)$ & $(2.510)$ & $(-2.442)$ & $(2.105)$ \\
\hline \multirow[t]{2}{*}{ INTERCEPT } & $95.559 * * *$ & $92.197 * * *$ & $96.646 * * *$ & $100.637 * * *$ & $94.928 * * *$ \\
\hline & (12.687) & $(11.675)$ & $(13.380)$ & $(7.784)$ & $(12.962)$ \\
\hline \multirow[t]{2}{*}{$G D P p c$} & $0.003 * * *$ & $0.003 * * *$ & $0.003 * * *$ & $0.003 * * *$ & $0.003 * * *$ \\
\hline & $(8.791)$ & (8.940) & $(7.776)$ & $(8.544)$ & $(8.536)$ \\
\hline \multirow[t]{2}{*}{ ALABORsh } & $-0.306 * *$ & $-0.302 * *$ & $-0.288 * *$ & $-0.396 * * *$ & $-0.299 * *$ \\
\hline & $(-2.464)$ & $(-2.369)$ & $(-2.410)$ & $(-3.159)$ & $(-2.442)$ \\
\hline \multirow[t]{2}{*}{ GNPgrowth } & $2.979 * * *$ & $3.168 * * *$ & $3.045 * * *$ & $2.475 * *$ & $3.088 * * *$ \\
\hline & $(2.791)$ & $(2.869)$ & $(2.966)$ & $(2.323)$ & $(2.935)$ \\
\hline \multirow[t]{2}{*}{$D E M O C R A C Y$} & -0.655 & -0.182 & -0.977 & -0.208 & -0.680 \\
\hline & $(-0.304)$ & $(-0.084)$ & $(-0.472)$ & $(-0.100)$ & $(-0.323)$ \\
\hline \multirow[t]{2}{*}{ TRADEintensity } & 1.585 & $3.353 *$ & 0.797 & 2.497 & 2.239 \\
\hline & $(0.775)$ & $(1.819)$ & $(0.422)$ & $(1.456)$ & $(1.276)$ \\
\hline Spatial weight matrix & $W^{C U_{-} E X P}$ & $W^{F T A \_E X P}$ & $W^{N N \_E X P}$ & $W^{S S_{-} E X P}$ & $W^{N S_{-} E X P}$ \\
\hline$R 2$ & 0.86 & 0.85 & 0.87 & 0.86 & 0.86 \\
\hline \multirow[t]{2}{*}{ Spatial BP-test } & 7.44 & 5.77 & 5.64 & 7.26 & 5.85 \\
\hline & $(0.19)$ & $(0.33)$ & $(0.34)$ & $(0.20)$ & $(0.32)$ \\
\hline \multirow[t]{2}{*}{ LR-test (spatial lag) } & 1.78 & 0.47 & $6.62 * *$ & $5.15 * *$ & $3.63 *$ \\
\hline & $(0.18)$ & $(0.49)$ & $(0.01)$ & $(0.02)$ & $(0.06)$ \\
\hline \multirow[t]{2}{*}{ LR-test (spatial error) } & 0.25 & $7.11 * * *$ & 0.29 & 0.01 & 0.45 \\
\hline & $(0.61)$ & $(0.00)$ & $(0.59)$ & $(0.92)$ & $(0.50)$ \\
\hline Number of obs. & 62 & 62 & 62 & 62 & 62 \\
\hline
\end{tabular}


The impact of trade on block members' environmental regulations seems to increase along the 'North-North' and 'South-South' dimension of RTAs (Models 3 and 4). The direction of this impact, however, is opposite to each other. Among the high income RTAs, trade will induce strong mimicking of environmental policies among members, with countries increasing their standards as a response to more stringent standards set by them trade partners. Trade among the low income RTAs, on the other hand, seems to contribute to further divergence of their environmental policies - putting downward pressure on environmental standards, at least for some members as a result of interaction. The magnitude of the policy reaction coefficient has almost tripled compared to Model 4 in Table 1. The negative effect of trade on environmental regulations among low income countries may reflect the fact that countries in 'South-South' RTAs may compete on the same export markets giving them more incentives to strategically lower their environmental policies in an effort to gain competitive advantage [Josling (1993)].

Our last two model specifications seem to support our earlier findings that trade between low income and high income countries (i.e. 'North-South' dimension of RTAs) has a positive effect on the stringency of environmental regulations (Model 5). The coefficients for the spatial interaction term $\left(W^{N S}\right)$ is positive and statistically significant, which suggests that liberalization of trade will induce to increase their environmental standards as an outcome of strategic interaction - a percentage increase of members stringency of environmental standards will increase a given country's standards by 0.2 percent. We explain this as follows. First, preferential trade arrangements between high income and low income countries may have been successful in inducing the economic growth in the latter group of countries, which may have increased income levels and thus more demand for environmental quality. Second, free trade agreements may have 
induced diversification away from traditional agricultural production (i.e. coffe, cocoa, banana, and sugar) into the manufacturing sector, which on the other hand reduce producers lobby resistance to environmental regulations. Third, high income (high stringency) countries may be able to induce low income (low stringency) countries to increase their stringency of environmental regulations through their asymmetric economic power position. Finally, free trade along 'North-South' dimension may also contribute to dissemination of knowledge and more environmental friendly technologies from high income countries to low income countries.

\section{CONCLUSIONS}

The purpose of this paper has been to analyze the effect of regional trading arrangements (RTAs) on the scope and level of environmental policies of their member countries. It has been widely believed among environmental groups that free trade agreements induce countries to harmonize their environmental policies downward [Charnovitz (1995)]. Our empirical results suggest that this may not be uniform across the different types of RTAs. The effect of RTAs on the environmental regulations differs both between the different forms of free trade agreements, as well as along the geographical and income dimensions. Our results suggest that a country's best policy response is to increase stringency of its environmental standards - countries mimic each other policies, which may lead to positive harmonization of environmental regulations. This is because CUs in general involve a higher degree of integration. This goes beyond free trade, such as establishment of common rules and institutions to mitigate the negative impact of competition among the members states. However, the impact of free 
trade agreements (FTAs) is ambiguous. The FTAs on the other hand, are based on a more loose form of integration with the main focus being the liberalization of trade among the member nations. This has an important policy implication. Our empirical results seem to support the argument that trade liberalization policies should be accompanied with parallel environmental agreements. Several regional trade agreements in 1990s have recognized this concern. For example, MERCOSUR includes positive harmonization of environmental policies among the members countries in an attempt to adopt uniform approach to transboundary polluters. In NAFTA, the environmental and trade commitments have been integrated with free trade agreements through parallel environmental agreements at the sectoral policy level. And free trade agreements under APEC call for effective cooperation among the member countries on environmental issues.

Second, our results suggest that there seems to be a strong interaction among countries in setting stringency of their environmental policies among high income RTAs (i.e. 'North-North' trade), while a divergence in environmental standards may take place among the members of low income trade blocks (i.e. 'South-South' trade). This result does not come as a surprise since the demand for environmental quality is higher among high-income countries than in low income countries, who struggle to meet the basic needs of their growing population. It suggests that equity issues are important in RTAs, since upward adjustment takes place among the high-income countries where income distribution is more equal ('North-North' RTAs), while increasing inequality in developing countries ('South-South' RTAs) may have contributed to downward pressure on environmental standards. 
The novel finding of this paper, however, is that free trade agreements among high income and low income countries ('North-South' trade direction) has a strong positive impact on environmental policies - low income countries seem to upgrade their regulations towards the level of high income countries. This result has an important policy implication. We cannot find the support to the claim that free trade between countries with stringent and lax environmental regulations will lead to strategic interaction where countries compete to each other by lowering their environmental standards. This is because the access to high income markets may be subject to low income countries committing themselves to certain public policy reforms, including improvement of their environmental performance. Contrary to widely believed arguments, our results suggest that free trade may be indeed a powerful force to induce developing countries to upgrade their environmental policies towards those of high income countries - the developing countries may in this sense be better served by the 'North-South' than 'South-South' free trade agreements. Stronger trade relations between high and low income countries may also give exposure to technology and knowledge transfers as well as novel ideas about the social and private benefits of environmentally friendly management approaches. 


\section{REFERENCES}

Anderson, K. and H. Norheim. (1993),. History, Geography and Regional Economic Integration. Centre for Economic Policy Research Discussion Paper, No. 795.

Anderson, K. (1996), Social Policy Dimensions of Economic Integration: Environmental and Labour Standards. National Bureau of Economic Research Working Paper 5702

Anselin, L. (1996), Interactive Techniques and Exploratory Spatial Data Analysis. Regional Research Institute Working Paper, West Virginia University.

Anselin, L. (1988), Spatial Econometrics: Methods and Models. Kluwer Academic Publishers.

Anselin, L. and A.K. Bera. (1998), Spatial Dependence in Linear regression Models with an Introduction to Spatial Econometrics. In A. Ullah and D. Giles (eds.), Handbook of Applied Economic Statistics, New York: Marcel Dekker.

Baldwin, R. (1995), Does Sustainability Require Growth. In The Economics of Sustainable Development, edited by I. Goldin and L.A. Winters, Cambridge: Cambridge University Press.

Barrett, S. (1994), "Strategic Environmental Policy and International Trade," Journal of Public Economics 54(3), pp. 325-38.

Ben-David, D. (1994), Income disparity among countries and the effects of freer trade. In Luigi L. Pasinetti and Robert M. Solow (eds.) Economic growth and the structure of long-run development. London: Macmillan, 45-64.

Ben-David, D. (1993), Equalizing Exchange: Trade Liberalization and Income Convergence. Quarterly Journal of Economics, Vol. 653-677

Beron K.J., J.C. Murdoch, and W.P.M. Vijverberg (1996), "Why Cooperate? An Independent Probit Model of Network Correlations," Working Paper, School of Social Sciences, University of Texas at Dallas.

Besley, T. and A. Case (1995), Incumbent behavior: vote-seeking, tax setting, and yardstick competition, American Economic Review, 85, 25-45.

Bommer, R. and G.G. Schulze (1999), "Environmental improvement with trade liberalization", European Journal of Political Economy, Vol. 15, No. 4: 639-61

Brueckner, J.K. (2001), Strategic Interaction Among Governments: An Overview of Empirical Studies. Mimeo. Department of Economics, University of Illinois at Urbana-Champaign.

Brueckner, J.K. (2000), Welfare Reform and the Race to the Bottom: Theory and Evidence. Southern Economic Journal, 66, 505-525

Brueckner, J.K. (1998), Testing for Strategic Interaction Among Local Governments: The Case of Growth Controls. Journal of Urban Economics 44, pp. 43867.

Case, A.C., H.S.Rosen, and J.R.Hines (1993), "Budget Spillovers and Fiscal Policy Interdependence," Journal of Public Economics 52, pp. 285-307. 

$16-45$

Charnovitz, S. (1995), Regional Trade Agreements. Environment. July/August:

Coe, D. T., E. Helpman and A. Hoffmaister. (1997), North-South R\&D Spillovers. The Economic Journal, 107: 134-149

Coe, D.T. and E. Helpman. (1995), International R\&D Spillovers, European Economic Review. 39: 859-887

Dasgupta, S., A. Mody, S. Roy, and D. Wheeler. (1995), Environmental Regulation and Development. A Cross-Country Empirical Analysis, Policy Research Working Paper \# 1448, Policy Research Department, World Bank.

Eliste, P. and P. Fredriksson. (2002), Environmental Regulations, Transfers and Trade: Theory and Evidence. Journal of Environmental Economics and Management. Vol 43., No. 2, pp. 234-250.

Eliste, P. and P.G. Fredriksson. (Fortcoming). "Does Open Trade Cause Race to the Bottom: An Empirical Evidence". In Luc Anselin and Raymond J.G.M. Florax (editors), New Advances in Spatial Econometrics, Springer Verlag.

Esty, D.C.and D. Geradin (1997), "Market Access, Competitiveness, and Harmonization: Environmental Protection in Regional Trade Agreements," The Harvard Environmental Law Review 21(2), pp. 265-336.

Fingelton, B. (1998), International Economic Growth: Simultaneous Equations Models Incorporating Regional Effects. Discussion Paper 98, Department of Land Economy, University of Cambridge.

Fredriksson, P.G. (1997), "The Political Economy of Pollution Taxes in a Small Open Economy," Journal of Environmental Economics and Management 33(1), pp. 4458.

Freedom House. (1991), Freedom in the World: Political Rights and Civil Liberties, Freedom House, New York.

Glover, D. (1999), Economic Growth and the Environment. Canadian Journal of Development Studies, Vol. XX, No. 3.

Hettne, B. (1998), The New Regionalism: Security and Development. In J.J. Teunissen (editor) Regional Integration and Multilateral Cooperation in the Global Economy, Fondad, The Hague.

Heyndels, B. and I.R. Prucha. (1998), Tax Mimicking Among Belgian Municipalities. National Tax Journal, 51,pp. 89-101

Isidro, S and A. Winters. (1999), How has Regionalism in the 1990s Affected Trade? The World Bank, Policy Research Working Paper, No. 2156, Washington, D.C.

Josling, T. (1993), Multilateralism: A Constraint on Unilateralism and Regionalism in Agricultural Trade. Amer. J. Agr. Econ. (August): 803:809

Jovanovic, M. (1998), International Economic Integration: Limits and Prospects. London: Routledge. 
Kennedy, P.W. (1994), Equilibrium Pollution Taxes in Open Economies with Imperfect Competition, Journal of Environmental Economics and Management 27, pp. 49-63.

Li, E. A. L. (1999), An Environmental Cooperation Agreement for the AsiaPacific region? The Australian Economic Review, Vol. 32, No. 2: 145-56

Nordhaus, W. D. (1994), Locational Competition and the Environment: Should Countries Harmonize their Environmental Policies. Cowles Foundation Discussion Paper, No. 1079.

O’Loughlin, J. and L. Anselin. (1996), Geo-Economic Competition and Trade Block Formation: United States, German, and Japanese Exports, 1968 - 1992. Economic Geography,

Onguglo, B. F. (1999), Developing Countries and Trade Preferences. In M. R. Mendoza, P. Low, and B. Kotscwas (eds) Trade Rules In the Making. Challenges in Regional and Multilateral Negotiations, Organization of American States, Brooking Institution Press, Washington, DC

Potters, J. and R. Sloof. (1996), Interest groups: A survey of empirical models that try to assess their influence. European Journal of Political Economy, 12, pp. 403-442. $822-40$.

Rauscher, M. (1994), On Ecological Dumping, Oxford Economic Papers 46(5), pp.

Robson, Peter. (1998), The Economics of International Integration. Routledge, London.

Saavedra, L. A. (2000), A Model of Welfare Competition With Evidence from AFDC. Journal of Urban Economics 47, 248-279.

Schiff, M. (2000), Multilateral Trade Liberalization and Political Disintegration: Implications for the Evolution of Free Trade Areas and Custom Unions. The World Bank, Policy Research Working Paper No. 2350, Washington, D.C.

Schiff, M. and L.A. Winters. (1998), Dynamics and Politics in Regional Integration Arrangements: An Introduction. The World Bank Economic Review, Vol 12 (2): $177-95$

Scully, G. W. and D. Slottje. (1991), Ranking Economic Liberty Across Countries, Public Choice, Vol. 69 (2), pp. 121-52.

Sjoholm, F. (1996), International Transfer of Knowledge: The Role of International Trade and Geographic Proximity. Weltwirtschaftkiches Archiv, Vol. 132(1): 97-115

Summers, R. and A. Heston (1989), The Penn World Tables (Mark 5): An Expanded Set of International Comparisons, 1950-1988, Quarterly Journal of Economics 106, pp. 327-69.

Tobey, J. A. (1991), The Effects of Environmental Policy Towards Agriculture on Trade. Food Policy, April:90-94

UNCED. (1992), Nations of the Earth Report, Vol. I-III, Geneva: United Nations. 
Venables, A. (1999), Regional Integration Agreements: a force for convergence or divergence. The World Bank, Policy Research Working Papers

Vamvakidis, A. (1998), Regional Integration and Economic Growth, The World Bank Economic Review 12(2), pp. 251-70. 
CHAPTER 4: ESSAY 3

\title{
Environmental Regulations, Transfers and Trade: Theory and Evidence ${ }^{i}$
}

\author{
Paavo Eliste ${ }^{*}$ \\ World Bank, 1818 H Street, N.W. \\ Washington, DC 20433 \\ and \\ Natural Resource Economics Program \\ West Virginia University \\ PO Box 6108 \\ Morgantown, WV 26506-6108 \\ Per G. Fredriksson \\ Department of Economics \\ Southern Methodist University \\ PO Box 750496 \\ Dallas, TX 75275-0496
}

\begin{abstract}
"Environmental Regulations, Transfers, and Trade: Theory and Evidence" by Paavo Eliste and Per G. Fredriksson, from Journal of Environmental Economics and Management, Volume 43, 234-250 (2002). Reprinted with permission from the publisher.
\end{abstract}

Copyright 2002, Elsevier Science (USA). All rights reserved.

Keywords: Political economy, Environmental regulations, Transfer payments. 


\begin{abstract}
This paper develops a theory of compensation of producers for the costs associated with environmental regulations. We show that the existence of transfers can give counterintuitive effects of environmental policy on both output and trade flows. In particular, the compensation obtained by producers neutralizes the effect of environmental policy on output, and consequently on trade flows. This may help explain why previous empirical research has found weak evidence that environmental regulations affect trade patterns. The theory is tested using agricultural sector data. The evidence supports the hypothesis that environmental regulations and transfers are positively correlated.
\end{abstract}




\section{INTRODUCTION}

Economic theory predicts that increased stringency of environmental regulations will result in lower exports and greater imports in polluting sectors (see, e.g., Baumol and Oates [4], Copeland and Taylor [9], Merrifield [35], Pethig [42]). For decades, researchers have attempted to verify these predictions empirically. However, this literature has largely found insignificant or small effects of environmental regulations on trade flows and firm location. For example, Kalt [29] and Tobey [46] find insignificant and mixed effects of environmental regulations on trade flows, respectively (see Jaffe [27] for an extensive survey). Recent empirical evidence from the manufacturing sector provided by van Beers and van den Bergh's [53] even indicates that more stringent environmental regulations may have given rise to greater exports. ${ }^{\text {ii }}$

The present paper provides a new explanation for why research has encountered difficulties in detecting the predicted effects. We argue that important aspects of environmental policy determination have been neglected. In particular, the political economy effects of environmental regulations have been ignored. We present a model that shows how polluting producers receive compensation for the costs associated with environmental protection. The existence of transfers to polluters is shown to yield counter-intuitive effects on trade patterns of higher pollution taxes. The compensation provided neutralizes the effect of the pollution tax on output, and therefore on imports and exports.

Our empirical work focuses on one of our theoretical predictions. Is government assistance positively related to the stringency of environmental policies? ?ii $^{i}$ Using agricultural sector data we provide evidence that supports this hypothesis. It follows that if a rise in the stringency of environmental policies brings about an increase in the 
transfers channeled to producers, then the increase in the stringency of environmental regulations will have a smaller total effect on output, and consequently on export and import flows, than otherwise would have been the case. ${ }^{\text {iv }}$ To our knowledge, this paper is the first attempt to explain the empirical relationship between environmental regulations and transfer policies. ${ }^{\mathrm{v}}$

The paper is organized as follows. Section 2 sets up a model which draws on the models of trade and tax policy determination by Dixit [12], Dixit et al. [13], and Grossman and Helpman [22]. This model has previously been extended by Aidt [1], Fredriksson [15,16,17], and Schleich [45] to address related issues in environmental policy determination. ${ }^{\mathrm{vi}}$ Section 3 defines the political equilibrium, and the theoretical results are discussed in section 4 . Section 5 describes the data and the empirical model, and section 6 discusses the empirical results. Section 7 offers a brief conclusion.

\section{THE THEORETICAL FRAMEWORK}

A small open economy has two sectors: one sector produces a clean numeraire $\operatorname{good} z$, the agricultural sector produces a polluting good $x$. The economy is populated by environmentalists (denoted by $E$ ), farmers $(F)$, and workers $(W)$, and the population is normalized to 1. Agricultural production requires a sector-specific factor: land. All individuals have labor income, farmers (land owners) in addition have factor income from agriculture. Environmentalists derive disutility from the pollution associated with the local production. An individual $k, k=E, F, W$, obtains a utility given by

$$
U^{k}=c^{z k}+u\left(c^{x}\right)-\delta^{E} \theta X,
$$

where $c^{z k}$ and $c^{x}$ are consumption of the numeraire good $z$ (by a type $k$ ) and good $x$, with world and domestic prices equal to 1 and $p^{*}$, respectively. ${ }^{\mathrm{vii}} u\left(c^{x}\right)$ is a strictly concave and 
differentiable sub-utility function, which yields aggregate consumer surplus from consumption of good $x$ equal to $C\left(p^{*}\right) . \delta^{E}$ is an indicator variable which takes a value of one if the individual is an environmentalist, and zero otherwise. Production of $x$ is given by $X$, and $\theta$ is the per-unit damage function. ${ }^{\text {viii }}$ Utility function (1) represents a case where the environmentalists are assumed to live downstream, or in the direction of the wind, from the production site. They suffer damage from, e.g., fertilizers, pesticides or odors.

Our discussion focuses on an endogenously determined production subsidy $s \in S$, $S \subset \mathrm{R}$, per unit of agricultural output. This subsidy is assumed set by the government department in charge of agricultural sector affairs, e.g. the Department of Agriculture. Another separate government unit, e.g. the Treasury or the Ministry of Environment, sets the tax on pollution from agricultural production. The pollution tax $t$ is assumed exogenous in this analysis.

Each individual has one unit of labor and the total labor endowment equals $l$. Good $z$ is produced by labor with a constant returns to scale technology, and an inputoutput coefficient equal to one. The labor supply is sufficiently large for the supply of $z$ to be positive which implies a wage rate equal to one. The inputs into production of good $x$ are labor and land. The technology is constant returns to scale. Ignoring labor costs, producers face a net price given by

$$
p=p^{*}(1+s)-t \theta
$$

Following Dixit [11], the factor reward (profit) function is given by

$$
\pi(p)=\frac{1}{2} g p^{2}-h p
$$

where $g$ and $h$ are parameters. This yields the supply function

$$
X(p) \equiv \pi_{p}(p)=g p-h .
$$


The government is assumed to distribute (collect) net revenues equal to

$$
\tau(t, s)=(g p-h)\left(t \theta-s p^{*}\right)
$$

uniformly to (from) all individuals. ${ }^{\text {ix }}$

Environmentalists and farmers organize exogenously into separate lobby groups coordinating campaign contribution offers to the government. The type of lobby group is denoted by $i, E$ for environmental and $F$ for farmer. The total membership of group $i$ equals $e$ and $f$, respectively, and $w$ is the number of workers, where $e^{+} f+w=1 .{ }^{\mathrm{x}}$

The model defines a two-stage game between the incumbent local government and the lobby groups. In stage one each lobby group $i$ offers the government a contribution schedule $\Lambda^{i}(s)$, taking the other lobby group's strategy as given. It offers the government a contribution for selecting the policy $s$. The incumbent government maximizes a weighed sum of aggregate campaign contributions and aggregate social welfare. Campaign contributions can be used for campaign advertising, whereas a higher average social welfare increases the probability of re-election. Workers do not make campaign payments. The gross utility of the environmental and farmer lobby groups are

$$
\Omega^{E}(t, s) \equiv e\left[-\theta X(p)+\tau(t, s)+l+C\left(p^{*}\right)\right],
$$

and

$$
\Omega^{F}(t, s) \equiv \Pi(p)+f\left[\tau(t, s)+l+C\left(p^{*}\right)\right],
$$

respectively, where $\left[\tau(t, s)+l+C\left(p^{*}\right)\right]$ is each lobby's share of net revenues, labor income, and aggregate consumer surplus. All individuals are concerned about net revenues since they benefit from (carry part of the burden of) a surplus (a deficit). In addition, given tax revenues, the farmers are better (worse) off by a higher subsidy (tax), and the 
environmentalists benefit (suffer) from the tax (subsidy) through a reduction (increase) in emissions. The gross aggregate social welfare is given by

$$
\Omega^{A}(t, s) \equiv \tau(t, s)+\Pi(p)-e \theta X(p)+l+C\left(p^{*}\right) .
$$

The government's utility function is given by

$$
G(t, s)=\Lambda^{E}(s)+\Lambda^{F}(s)+a \Omega^{A}(t, s),
$$

where $a \geq 0$ is the government's exogenously given weight on aggregate social welfare relative to political contributions. ${ }^{\mathrm{xi}}$ In stage two, the government selects its optimal subsidy policy, given the lobby groups' strategies, and receives from each lobby the corresponding contribution. ${ }^{\mathrm{xii}}$

\section{THE POLITICAL EQUILIBRIUM}

Bernheim and Whinston [7] and Grossman and Helpman [22] imply that we can characterize the equilibrium using the following two necessary conditions: ${ }^{\text {xii }}$

$$
\begin{aligned}
& s^{o}=\underset{s}{\arg \max } \sum_{i \in E, F} \Lambda^{i o}(s)+a \Omega^{A}(t, s) \text { on } S ; \\
& s^{o}=\underset{s}{\arg \max } \Omega^{j}(t, s)-\Lambda^{j o}(s)+\sum_{i \in E, F} \Lambda^{i o}(s)+a \Omega^{A}(t, s) \text { on } S \text { for every } j .
\end{aligned}
$$

Assume that the contribution schedules are differentiable around the equilibrium point $s^{0}$. Conditions (C1) and (C2) imply that the following condition holds at the equilibrium $s^{\text {o.xiv }}$

$$
\Omega_{s}^{j}\left(t, s^{o}\right)=\Lambda_{s}^{j^{o}}\left(s^{o}\right), \quad \forall j
$$


Substituting (10) into the first-order condition of (C1), we obtain

$$
\sum_{i \in E, F} \Omega_{s}^{i}\left(t, s^{\circ}\right)+a \Omega_{s}^{A}\left(s^{\circ}\right)=0 .
$$

Equation (11) is the equilibrium characterization of the subsidy.

\section{THEORETICAL RESULTS}

In this section we first determine the equilibrium subsidy policy. Second, we analyze the effect of an increase in the pollution tax on the subsidy, and third, the total effect of the pollution tax on trade flows. As a point of reference, note that the Pigouvian tax equals $e$ (the number of environmentalists) as long as $s=0$, since $e$ is the marginal disutility of pollution. This can be seen from the first-order condition of (8), the government's welfare function, which yields $X-t \theta X_{p}-X+e \theta X_{p}=0=>t=e$.

However, when $s \neq 0$ the optimal tax equals $t=e+p^{*} s / \theta \neq e$. This is because this tax is now second-best and must address two distortions, pollution and the production subsidy. The optimal subsidy equals $s=(t-e) \theta$, i.e. $s=0$, as long as $t=e$.

The equilibrium subsidy level can be found by taking the partial derivative of Equations (6), (7), and (8) with respect to $s$ [making use of Equations (3)-(5)], substitute the result into Equation (11), and rearrange. In equilibrium, the production subsidy satisfies

$$
s^{o}=\frac{(e+f-1)\left[\left(t \theta-p^{*}\right) g+h\right]+[(e+f+a) t-(1+a) e] \theta g}{[(e+f) 2+a-1] p^{*} g} .
$$

The sign of expression (12) is ambiguous. For consistency we assume that the denominator is positive, i.e., $(e+f) 2+a-1>0 .{ }^{\mathrm{xv}}$ The intuition is the following. The first term in the numerator, $(e+f)\left[\left(t \theta-p^{*}\right) g+h\right]<0$, is the lobby group members' 
combined pressure against the subsidy in their role as taxpayers, and the second term, $-\left[\left(t \theta-p^{*}\right) g+h\right]>0$, is the farmer lobby's political pressure for a greater subsidy. These pressures are proportional to the output level net of the subsidy's effect $\left[\left(p^{*}-t \theta\right) g-h\right]$. The net pressure from the first two terms is negative if $e+f<1$. The third term in the numerator, $(e+f+a) t \theta g$, represents the pressure by all individuals for a greater subsidy due to its positive effect on pollution tax revenues (where lobby group membership again adds political weight), and the forth term, $-(1+a) e \theta g$, is the environmental lobby group's pressure for a lower subsidy. Note that the latter two effects are proportional to the marginal damage of output, $\theta$. The denominator adjusts these pressures by the cost of the subsidy, reflected by $p^{*}$. This tax payer pressure grows stronger the greater the share of the population that is organized into lobby groups. Finally, notice that as the weight $a$ on social welfare increases, the subsidy approaches zero if the Pigouvian tax is implemented, i.e. $s^{o} \rightarrow 0$ as $a \rightarrow \infty$ if $t=e$.

We now find the effect of the pollution tax on the equilibrium subsidy. Totally differentiating Equation (12) yields

$$
\frac{d s}{d t}=\frac{\theta}{p^{*}}>0
$$

The model predicts that an increase in the tax rate yields an increase in the subsidy rate, i.e. $t$ and $s$ are complements. This implies that farmers are compensated for a greater pollution tax with a compensating subsidy (transfer). The rate of change is proportional to the pollution intensity, but inversely related to the world market price. Thus, the more costly is a tax hike to the farmers (the more pollution intensive is production, represented by $\theta$ ), the greater their compensation through the subsidy. However, the more costly is the subsidy to the taxpayers (i.e., the greater is $p^{*}$ ), the lower the rate of increase. 
In order to study the effect of the pollution tax on the pattern of foreign trade, we define net imports as $M(p)=p^{*}\left[d\left(p^{*}\right)-X(p)\right]$, and net exports as $-M(p)$. Using Equation (13), differentiation yields

$$
\frac{d M(p)}{d t}=p^{*}\left(\theta X_{p}-p^{*} X_{p} \frac{\theta}{p^{*}}\right)=0 .
$$

Similarly for exports, $d[-M(p)] / d t=0$. Thus, the model predicts that the compensation received by farmers for an increase in the tax exactly cancels the direct effect of the tax on output, and thus on import and export flows. ${ }^{\text {xvi }}$ Note that since the model abstracts from abatement efforts, the effect of the pollution tax and the production subsidy on output and pollution are related in a linear fashion [see Equation (2)], and thus the lobby group pressures are also linearly related (but adjusted by $p^{*}$ and $\theta$, respectively). The government's weights on the special interest groups therefore cancel each other out in Equation (14).

\section{EMPIRICAL ANALYSIS}

The theory developed predicts that an increase in the stringency of environmental policy leads to a rise in the level of transfers to producers. It is the aim of our empirical analysis to test this prediction, i.e. we focus on the "compensation" hypothesis. Assuming that the countries in our data set are small on the world market (as in the theoretical model), the empirical result would also indirectly give insights into the consequent total effect of environmental regulations on trade flows, although we do not perform an explicit analysis of trade patterns. ${ }^{\text {xvii }}$

In our view, compensation channelled to farmers in return for more stringent environmental regulations may come through a variety of policies. Whereas the 
theoretical model provides the intuition for only one such transfer form, governments may use, e.g., production-, export-, investment-, or pollution abatement subsidies, or use land set aside schemes, import restrictions, and tax concessions. Our empirical work takes this into account.

\section{Data on Environmental Regulations and Transfers}

We use cross-country data from 62 countries for the year 1990. Our measure of the stringency of environmental regulations in the agricultural sector $(S T R I N G)$ is an index constructed by Dasgupta et al. [10]. This index has the advantage of measuring the stringency of environmental regulations in the agricultural sector alone. It is based on country reports for the 1992 United Nations Conference on Environment and Development in Rio (UNCED [48]) on the existing environmental regulations facing the agricultural sector. Each country report is in turn based on survey questions and was prepared under well-defined UNCED guidelines, making a cross-country comparison possible (see Dasgupta et al. [10]). The reports provide specific information about the state of the environmental regulatory framework, focusing on existing environmental policies, legislation, control mechanisms, and enforcement. ${ }^{\text {xviii }}$ Using the information gathered, a quantitative index was developed by Dasgupta et al. [10] for a set of 31 countries by assigning the answers on each of 25 questions a score from 0 to 2 . Each question posed was answered with regards to water pollution, air pollution, land use, and biodiversity, and the scores were added to yield an index with a maximum of 200. The data set was extended by us to 62 countries using the same methodology as Dasgupta et al. [10]. 
We use the Producer Subsidy Equivalent (PSE) in the agricultural sector as a measure of aggregate transfers (measures of the PSE are available only for 50 countries, however). The PSE measures the monetary value of all transfers to the agricultural sector, including tariffs, non-tariff barriers, and various compensation schemes for environmental regulations resulting from agricultural regulatory policies. ${ }^{\text {xix }}$ To reduce the effects of the volatility between years (due to, e.g., large exchange rate fluctuations), we use the average PSE for the three years 1988-90. All data sources, adjustments due to missing observations, and descriptive statistics are listed in tables A.I and A.II in the appendix. $^{\text {xx }}$

\section{Empirical Model}

Our theory predicts that environmental regulations (pollution taxes) cause transfer payments to polluters. Transfer payments may, however, in turn influence the stringency of regulations. This feedback effect suggests that environmental regulations and producer transfers may both be endogenously determined. To account for the possible endogeneity bias we employ a 2SLS estimator, which is robust to possible misspecifications. We estimate two equations, one explaining PSE, and the other explaining STRING.

First, the main prediction emerging from our model is that an increase in the pollution tax results in an increase in the production subsidy. Thus, STRING should have a positive sign in the PSE equation. Next, the political pressure from the farmer lobby group depends on the incentive to spend resources on lobbying. ${ }^{\text {xxi }}$ We use the share of value added in agriculture to total GDP (AGDPsh) and the share of agricultural sector labor in the total labor force as a proxy for the political pressure of the farmer lobby group (AGLABORsh). ${ }^{\text {xii }}$ The expected effect of AGLABORsh is ambiguous, however. 
First, a small change in the PSE has a larger aggregate effect on the farmer lobby group's welfare as $A G L A B O R s h$ increases because this implies a relatively greater number of transfer recipients. This may translate into greater lobbying pressure and voting power (in democracies), having a positive effect on the PSE (see Potters and Sloof [43]). On the other hand, the farmer lobby group suffers from increased free-riding as the number of farmers increases, and thus the pressure for assistance may decrease, as argued by Olson [41]. ${ }^{\text {xiii }}$ Third, as the agricultural producers' share of the total labor force increases it becomes more costly for the government to transfer income to farmers because the share of the remaining population necessarily falls. Each unit of income extracted from the remaining population consequently yields a smaller marginal benefit to each farmer as their numbers increase, and a greater marginal cost to the remaining population. If the first (second and third) effect(s) dominate(s), AGLABORsh has a positive (negative) impact on PSE.

The producers' ability to obtain government transfers is greater the lower the deadweight costs associated with redistribution [see Becker [5] and Gardner [20]]. Redistribution via a production subsidy (and other programs) is more costly the greater the elasticity of output supply. This is because of the greater negative impact on the price. Thus, the PSE should be lower the greater is the supply elasticity. Since cross-country supply elasticity estimates are unavailable we use a proxy variable. The difference in the elasticity of supply across countries should be reflected by the value added per hectare of agricultural land (VALUEph). A high per hectare value added corresponds to a low elasticity of supply because the available resources are allocated in a way that maximizes value added. A further increase in the subsidy should yield a lower marginal output response, and thus a greater effect on the price faced by producers. ${ }^{\text {xiv }}$ 
Beghin and Kherallah [6] report that democratic countries tend to have greater levels of protection. We use two measures of democracy as controls. Following Murdoch and Sandler [37] we add the Freedom House [19] indices for (i) political rights and (ii) civil liberties into one index (FREE). The two Freedom House indices take a value of 1 for a completely free country, and 7 for the least free country. Thus FREE ranges from 1 to 14, and we expect a negative sign. Freedom House [19] also classifies countries into three groups: free, partially free and not free. We define a dummy DEMOCRACYdummy, which takes value 1 when the country is free (democratic) and zero otherwise. We expect a positive sign.

We now discuss the determinants of STRING. Because environmental regulations and transfers may be simultaneously determined, we include our measure of transfers, $P S E$. We also use per capita income (GDPpc), AGDPsh, and AGLABORsh as measures of environmental and producer lobby group pressures (see Bardhan [2] and Potters and Sloof [43]). The share of agricultural land to the total land area (AGLANDsh) and fertilizer use per hectare (FERTph) both reflect environmental pressures. Finally, Barrett and Graddy [3], Congleton [8], Fredriksson and Gaston [18], and Murdoch and Sandler [37] report that more democratic countries tend to value environmental quality to a relatively greater degree. We use the same indictors of the level of democracy as for the PSE equation.

The specifications for the stringency of environmental regulations and government transfers are consequently given by

$$
\begin{gathered}
\operatorname{STRING}_{i}=\beta_{11}+\gamma_{1} \text { PSE }_{i}+\beta_{12} \text { GDPpc }_{i}+\beta_{13} \text { AGDPsh }_{i}+\beta_{14} \text { FERTph }_{i} \\
+\beta_{15} \text { AGLANDsh } i+\beta_{16} J_{i}+\varepsilon_{l i} \\
\text { PSE }_{i}=\beta_{21}+\gamma_{2} \text { STRING }_{i}+\beta_{22} \text { AGLABORsh }_{i}+\beta_{23} \text { VALUEph }_{i}+\beta_{24} J_{i}+\varepsilon_{2 i},
\end{gathered}
$$


where $i$ denotes individual country $i, i=1, \ldots N, J=1,2$, corresponds to our alternative democracy measures, $\beta$ are the exogenous variable coefficients, $\gamma$ are the coefficients on the endogenous variables, and $\varepsilon$ are the iid error terms.

\section{EMPIRICAL RESULTS}

Diagnostics

The condition index for the reduced form equations ranges from 10.85 to 14.31 in the base models (Table I, models 1-3) which reveals no presence of multicollinearity. Using the Breusch-Pagan Lagrange Multiplier test, the null hypothesis of homoscedasticity of the structural residuals was rejected at least at the 10 percent level. We therefore use White heteroscedasticity adjusted 2SLS to estimate the system of equations (White [54]). The results are presented in table I. 


\begin{tabular}{|c|c|c|c|c|c|}
\hline & MODEL 1 & MODEL 2 & MODEL 3 & MODEL 4 & MODEL 5 \\
\hline \multicolumn{6}{|c|}{ Dependent variable: STRING } \\
\hline INTERCEPT & $\begin{array}{c}83.193^{* * *} \\
(8.135)\end{array}$ & $\begin{array}{c}78.279^{* * *} \\
(6.300)\end{array}$ & $\begin{array}{c}81.388^{* * *} \\
(9.839)\end{array}$ & $\begin{array}{c}93.491^{* * *} \\
(4.376)\end{array}$ & $\begin{array}{c}82.113^{* * *} \\
(4.196)\end{array}$ \\
\hline$P S E$ & $\begin{array}{c}-0.008 \\
(-0.035)\end{array}$ & $\begin{array}{c}0.003 \\
(0.015)\end{array}$ & $\begin{array}{c}0.038 \\
(0.221)\end{array}$ & $\begin{array}{c}-0.628 \\
(-0.753)\end{array}$ & $\begin{array}{c}-0.618 \\
(-0.724)\end{array}$ \\
\hline GDPpc & $\begin{array}{l}0.004^{* * *} \\
(5.981)\end{array}$ & $\begin{array}{l}0.004^{* * *} \\
(5.951)\end{array}$ & $\begin{array}{l}0.004^{* * *} \\
(6.074)\end{array}$ & $\begin{array}{l}0.005^{* * *} \\
(2.962)\end{array}$ & $\begin{array}{l}0.005^{* * *} \\
(2.897)\end{array}$ \\
\hline$A G D P s h$ & $\begin{array}{l}-0.568^{*} \\
(-1.813)\end{array}$ & $\begin{array}{l}-0.567^{*} \\
(-1.827)\end{array}$ & $\begin{array}{l}-0.622^{* *} \\
(-2.143)\end{array}$ & - & - \\
\hline AGLABORsh & - & - & - & $\begin{array}{c}-0.490 \\
(-1.239)\end{array}$ & $\begin{array}{c}-0.551 \\
(-1.168)\end{array}$ \\
\hline AGLANDsh & $\begin{array}{l}0.235^{* *} \\
(2.077)\end{array}$ & $\begin{array}{l}0.239^{* *} \\
(2.109)\end{array}$ & $\begin{array}{l}0.239^{* *} \\
(2.161)\end{array}$ & $\begin{array}{c}0.175 \\
(0.841)\end{array}$ & $\begin{array}{c}0.181 \\
(0.865)\end{array}$ \\
\hline FERTph & $\begin{array}{c}0.028 \\
(1.023)\end{array}$ & $\begin{array}{c}0.027 \\
(1.042)\end{array}$ & $\begin{array}{c}0.024 \\
(1.015)\end{array}$ & $\begin{array}{c}0.066 \\
(1.235)\end{array}$ & $\begin{array}{c}0.064 \\
(1.181)\end{array}$ \\
\hline FREE & $\begin{array}{c}-0.482 \\
(-0.309)\end{array}$ & - & - & $\begin{array}{l}-1.532 \\
(0.738)\end{array}$ & - \\
\hline DEMOCRACYdummy & - & $\begin{array}{c}3.230 \\
(0.338)\end{array}$ & - & - & $\begin{array}{c}6.687 \\
(0.727)\end{array}$ \\
\hline Adj. $R^{2}$ & 0.83 & 0.83 & 0.83 & 0.58 & 0.58 \\
\hline \multicolumn{6}{|c|}{ Dependent variable: PSE } \\
\hline INTERCEPT & $\begin{array}{l}-21.475 \\
(-0.603)\end{array}$ & $\begin{array}{l}-31.340 \\
(-0.987)\end{array}$ & $\begin{array}{l}-25.729 \\
(-0.825)\end{array}$ & $\begin{array}{l}-36.913 \\
(-1.072)\end{array}$ & $\begin{array}{l}-69.355^{*} \\
(-1.918)\end{array}$ \\
\hline STRING & $\begin{array}{l}0.428^{* *} \\
(2.048)\end{array}$ & $\begin{array}{l}0.439^{* *} \\
(2.189)\end{array}$ & $\begin{array}{l}0.445^{* *} \\
(2.271)\end{array}$ & $\begin{array}{l}0.537^{* * *} \\
(2.673)\end{array}$ & $\begin{array}{l}0.634^{* * *} \\
(3.140)\end{array}$ \\
\hline AGLABORsh & $\begin{array}{c}-0.466 \\
(-1.087)\end{array}$ & $\begin{array}{c}-0.482 \\
(-1.142)\end{array}$ & $\begin{array}{c}-0.558 \\
(-1.376)\end{array}$ & - & - \\
\hline$A G D P s h$ & - & - & - & $\begin{array}{c}0.290 \\
(0.316)\end{array}$ & $\begin{array}{c}-0.034 \\
(-0.041)\end{array}$ \\
\hline VALUEph & $\begin{array}{c}0.003^{*} \\
(1.782)\end{array}$ & $\begin{array}{l}0.003^{*} \\
(1.815)\end{array}$ & $\begin{array}{l}0.003^{*} \\
(1.805)\end{array}$ & $\begin{array}{c}0.003^{*} \\
(1.676)\end{array}$ & $\begin{array}{l}0.003^{*} \\
(1.700)\end{array}$ \\
\hline FREE & $\begin{array}{c}-0.956 \\
(-0.378)\end{array}$ & - & - & $\begin{array}{c}-3.628 \\
(-1.109)\end{array}$ & - \\
\hline DEMOCRACYdummy & - & $\begin{array}{c}6.091 \\
(0.372)\end{array}$ & - & - & $\begin{array}{l}10.037 \\
(0.585)\end{array}$ \\
\hline $\operatorname{Adj} . R^{2}$ & 0.45 & 0.44 & 0.46 & 0.42 & 0.39 \\
\hline Obs. & 50 & 50 & 50 & 50 & 50 \\
\hline
\end{tabular}




\section{Analysis of Results}

We begin with a brief summary of results of the estimation of the STRING equation. The fit of our base models (1-3) is good, since the adjusted $R^{2}$ is between 0.82 and 0.83 . The coefficient estimate for PSE is insignificant in all models, GDPpc is positive and significant at the 1 percent level, $A G D P$ sh is negative and significant at least at the 10 percent level. ${ }^{\mathrm{xxv}}$ The coefficient for $A G L A N D$ sh is positive and significant at the 5 percent level, whereas FERTph is insignificant. The democracy measures have no significant impact on STRING. .xvi $^{\text {. }}$

Turning to the estimates of our primary equation for transfers in table I, we find support for the hypothesis that STRING is positively related to the PSE. The coefficient is significant at the 5 percent level in all model specifications. It appears that farm production subject to environmental regulations receive compensation, and this is greater the more stringent the regulations. Our theory and empirical evidence, as well as research in other policy areas suggest that compensation may have taken place. ${ }^{\text {xxvii }}$ However, it should be pointed out that this is a cross-sectional analysis since STRING data is available only for year 1990. It should also be noted that not all transfers are compensation for environmental regulations. For example, U.S. farmers have benefited from support programs since the 1930s (Gardner [20]). Not until the 1970s and 1980s did environmental regulations become common, and thus compensation for these policies cannot have occurred until then. Thus, it is necessary to exercise some caution in the interpretation of the findings. Figure 1 confirms the increased relative importance of transfers given with an explicit environmental objective in the U.S. (although other forms of transfers may also serve as compensation). Their share of agricultural subsidies has increased significantly since the mid-1980s. ${ }^{\text {xviii }}$ 


\section{Figure 1: Direction of Agricultural Subsidies, United States 1985-94}

(Share of totals) $^{a}$

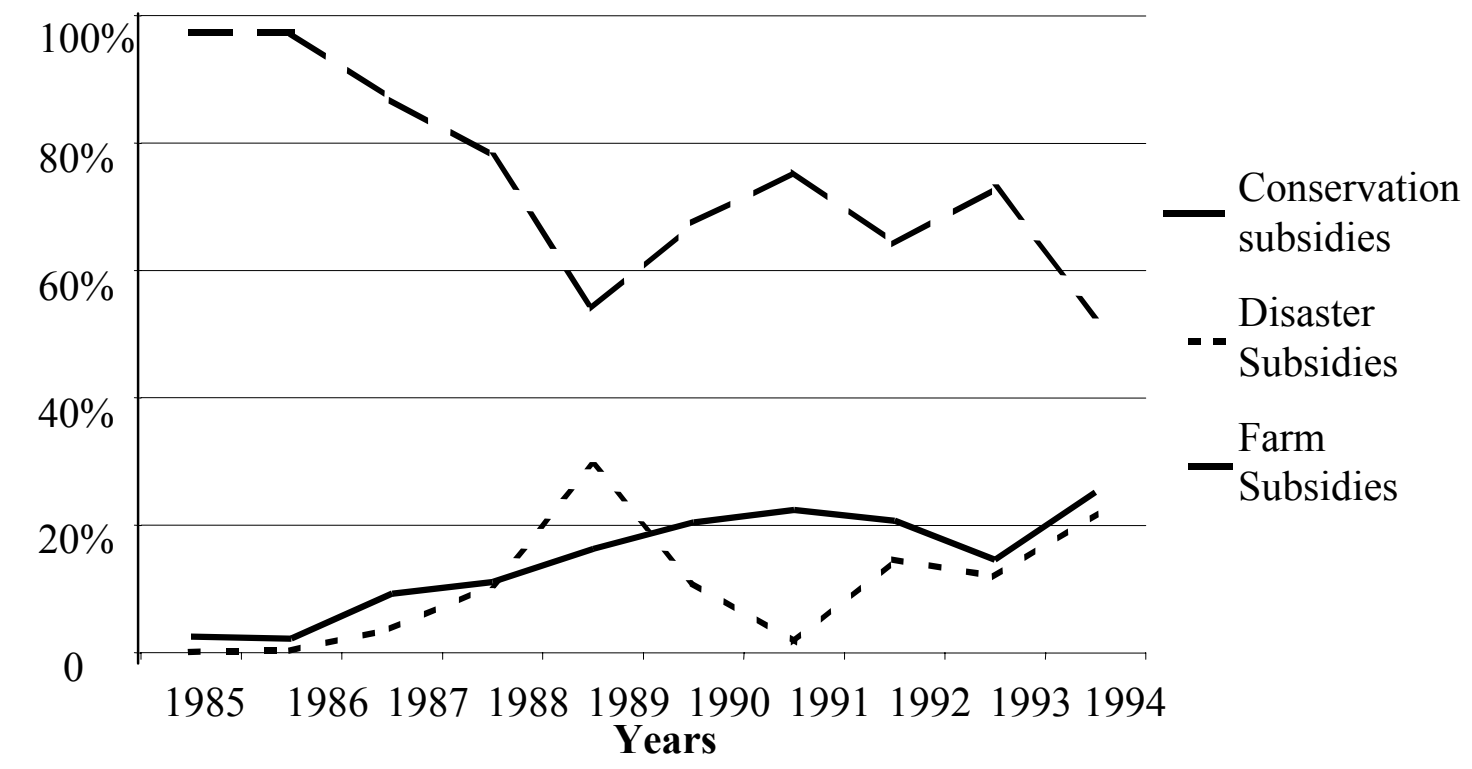

${ }^{a}$ Source: Environmental Working Group, http://www.ewg.org

AGLABORsh is insignificant in all models. ${ }^{\text {xix }}$ The VALUEph variable has the expected positive sign and is significant at least at the 10 percent level indicating that the cost of redistribution falls as the elasticity of supply falls. ${ }^{\mathrm{xx}}$ Finally, all democracy variables are insignificant. Models 4 and 5 in Table I present alternative specifications, where $A G D P s h$ and $A G L A B O R s h$ are exchanged. Our main conclusion remains the same since STRING becomes significant at the 1 percent level.

An important question is whether the results are sensitive to individual observations. It would be a source of concern if individual observations drive our results completely. An examination of the residuals reveals two distinct outliers; Zambia and Iceland. Dropping these observations yields a marginal improvement of the fit of all base models, see table II. There is an improvement in the significance of the point estimates 
for STRING, and the coefficient for VALUEph now becomes significant at the 5 percent level.

Table II: Sensitivity analysis ${ }^{a}$

\begin{tabular}{|c|c|c|c|}
\hline & MODEL 1 & MODEL 2 & MODEL 3 \\
\hline \multicolumn{4}{|c|}{ Dependent variable: STRING } \\
\hline & $87.204^{* * *}$ & $82.051^{* * *}$ & $82.426^{* * *}$ \\
\hline INIEKCEPI & (7.284) & $(7.956)$ & $(9.051)$ \\
\hline$P S E$ & -0.183 & -0.136 & -0.093 \\
\hline & $(-0.774)$ & $(-0.560)$ & $(-0.343)$ \\
\hline$G D P p c$ & $\begin{array}{c}0.005^{* * *} \\
(6.126)\end{array}$ & $\begin{array}{l}0.005^{* * * *} \\
(6.219)\end{array}$ & $\begin{array}{l}0.005^{* * * *} \\
(5.739)\end{array}$ \\
\hline$A G D P s h$ & $\begin{array}{l}-0.512^{*} \\
(-1.701)\end{array}$ & $\begin{array}{l}-0.631^{* *} \\
(-2.085)\end{array}$ & $\begin{array}{l}-0.616^{* *} \\
(-2.121)\end{array}$ \\
\hline AGLANDsh & $\begin{array}{c}0.183 \\
(1.579)\end{array}$ & $\begin{array}{c}0.191^{*} \\
(1.733)\end{array}$ & $\begin{array}{l}0.194^{*} \\
(1.808)\end{array}$ \\
\hline FERTph & $\begin{array}{c}0.023 \\
(1.334)\end{array}$ & $\begin{array}{c}0.019 \\
(0.979)\end{array}$ & $\begin{array}{c}0.019 \\
(1.180)\end{array}$ \\
\hline FREE & $\begin{array}{c}-1.042 \\
(-0.679)\end{array}$ & - & - \\
\hline DEMOCRACYdummy & - & $\begin{array}{c}1.011 \\
(0.167)\end{array}$ & - \\
\hline $\operatorname{Adj} . R^{2}$ & 0.83 & 0.84 & 0.85 \\
\hline
\end{tabular}

Dependent variable: PSE

INTERCEPT

$-21.204 \quad-36.921 \quad-29.114$

STRING

$(-0.682) \quad(-1.380) \quad(-1.112)$

$0.395^{* *} \quad 0.389^{* *} \quad 0.426^{* *}$

$(2.279) \quad(2.243) \quad(2.710)$
-0.151

AGLABORsh

$-0.151-0.232$

$-0.310$

VALUEph

$\begin{array}{ccc}(-0.426) & (-0.828) & (-1.118) \\ 0.003^{* *} & 0.005^{* *} & 0.003^{* *}\end{array}$

FREE

(2.164)

(1.983)

(2.229)

$-1.708$

$(-0.677)$

DEMOCRACYdummy

12.539
$(0.766)$

$\operatorname{Adj} . R^{2}$

0.48

0.46

0.50

Obs.

$48 \quad 48 \quad 48$

${ }^{a * * *}\left({ }^{* *}\right)\left[{ }^{*}\right]$ denotes significant at the 1 (5) [10] percent level. 


\section{CONCLUSIONS}

This paper provided a theoretical model that showed how production subsidies channelled to regulated producers as compensation for greater pollution taxes mitigated the effect of pollution taxes on output, and therefore on exports and imports (employing the small open economy assumption of constant world market and consumer prices). Our empirical findings indicate that more stringent environmental regulations tend to be associated with greater transfers in the agricultural sector. We believe this is a new finding in the literature.

Future research may investigate whether transfers have neutralized the effects of environmental regulations also in the manufacturing sector, and explicitly study the combined effects of environmental policies and associated transfers on trade flows. ${ }^{\text {xxi }}$ 


\section{REFERENCES}

1. T.S. Aidt, Political internalization of economic externalities and environmental policy, J. Public Econom. 69, 1-16 (1998).

2. P.K. Bardhan, "The Economic Theory of Agrarian Institutions," Oxford University Press, New York, NY (1989).

3. S. Barrett and K. Graddy (2000), Freedom, growth, and the environment, Environment Development Econom. 5, 433-456.

4. W.J. Baumol and W.E. Oates, "The Theory of Environmental Policy," 2nd ed., Cambridge Univ. Press, Cambridge, MA (1988).

5. G. Becker, A theory of competition among pressure groups for political influence, Quart. J. Econom. 98, 371-400 (1983).

6. J. C. Beghin and M. Kherallah, Political institutions and international patterns of agricultural protection, Rev. Econom. Statist. 76, $482-489$ (1994).

7. B.D. Bernheim and M.D. Whinston, Menu auctions, resource allocation, and economic influence, Quart. J. Econom. 101, 1-31 (1986).

8. R.D. Congleton, Political institutions and pollution control, Rev. Econom. Statist. 74, 412-421 (1992).

9. B.R. Copeland and M.S. Taylor, North-south trade and the environment, Quart. J. Econom. 109, 755-787 (1994).

10. S. Dasgupta, A. Mody, S. Roy, and D. Wheeler, Environmental regulation and development. A cross-country empirical analysis, Policy Research Working Paper \# 1448, Policy Research Department, World Bank (1995).

11. A. Dixit, Special-interest lobbying and endogenous commodity taxation, Working Paper 68.95, Fondazione Eni Enrico Mattei (1995). 
12. A. Dixit, Special-interest lobbying and endogenous commodity taxation, Eastern Econom. J. 22, 375-38 (1996).

13. A. Dixit, G.M. Grossman, and E. Helpman, Common agency and coordination: General theory and application to government policy making, J. Pol. Economy 105, 752-769 (1997).

14. EWG, "The Cash Croppers," Environmental Working Group \& The Tides Foundation, Washington, DC (1995).

15. P.G. Fredriksson, The political economy of pollution taxes in a small open economy, J. Environ. Econom. Management 33, 44-58 (1997).

16. P.G. Fredriksson, Environmental policy choice: Pollution abatement subsidies, Resour. Energy Econom. 20, 51-63 (1998).

17. P.G. Fredriksson, The political economy of trade liberalization and environmental policy, Southern Econom. J. 65, 513-525 (1999).

18. P.G. Fredriksson and N. Gaston, Ratification of the 1992 climate change convention: What determines legislative delay?, Public Choice 104, 345-368 (2000).

19. Freedom House, "Freedom in the World: Political Rights and Civil Liberties," Freedom House, New York, NY (1991).

20. B.L. Gardner, Causes of U.S. farm commodity programs, J. Pol. Economy 95, 290310 (1987).

21. B.L. Gardner, Environmental regulation and the competitiveness of U.S. agriculture, in "Agriculture, Trade, and the Environment: Discovering and Measuring the Critical Linkages” (M.E. Bredahl, N. Ballanger, J.C. Dunmore, T.L. Roe, Eds.), Westview Press, Boulder, CO (1996). 
22. G.M. Grossman and E. Helpman, Protection for sale, Amer. Econom. Rev. 84, 833850 (1994).

23. G.M. Grossman and A.B. Krueger, Environmental impacts of North American free trade agreement, in "The U.S.-Mexico Free Trade Agreement” (P. Garber, Ed.), MIT Press, Cambridge, MA (1993).

24. J.M. Guttman, Interest groups and the demand for agricultural research, J. Pol. Economy 86, 467-484 (1978).

25. H. Hettige, R.E.B. Lucas, and D. Wheeler, The toxic intensity of industrial production: Global patterns, trends, and trade policy, Amer. Econom. Rev., P.\&P. 82, 478-481 (1992).

26. A. Hillman and H. Ursprung, Environmental protection and international trade policy, in "The International Dimension of Environmental Policy" (C. Carraro, Ed.), Kluwer, Boston, MA (1994).

27. A.B. Jaffe, S.R. Peterson, P.R. Portney, and R. Stavins, Environmental regulation and the competitiveness of U.S. manufacturing, J. Econom. Lit. 33, 132-163 (1995).

28. R.E. Just and N. Bockstael, "Commodity and Resource Policies in Agricultural Systems,” (Eds.), Springer-Verlag, Berlin and New York (1991).

29. J.P. Kalt, The impact of domestic environmental regulatory policies on U.S. international competitiveness," in "International Competitiveness" (A.M. Spence and H.A. Hazard, Eds.), Harper and Row, Ballinger, Cambridge, MA (1988).

30. M.P. Leidy and B.M. Hoekman, 'Cleaning up' while cleaning up? Pollution abatement, interest groups and contingent trade policies, Public Choice 78, 241-28 (1994). 
31. J. Lewandrowski, J. Tobey, and Z. Cook, The interface between agricultural assistance and the environment: Chemical fertilizer consumption and area expansion, Land Econom. 73, 404-427 (1997).

32. J.A. List and C.Y. Co, The effects of environmental regulations on foreign direct investment, J. Environ. Econom. Management 40, 1-20 (2000).

33. P. Low and A. Yeats, Do 'dirty' industries migrate?, in "International Trade and the Environment” (P. Low, Ed.), World Bank Discussion Paper \#159, World Bank (1992).

34. H.P. Marvel, and E.J. Ray, The Kennedy Round: Evidence on the regulation of international trade in the United States, Amer. Econom. Rev. 73, 190-197 (1983).

35. J.D. Merrifield, The impact of selected abatement strategies on transnational pollution, the terms of trade, and factor rewards: A general equilibrium approach, $J$. Environ. Econom. Management 15, 259-24 (1988).

36. T.C. Miller, Agricultural price policies and political interest group competition, $J$. Policy Modeling 13, 489-513 (1991).

37. J. C. Murdoch and T. Sandler, The voluntary provision of a pure public good: The case of reduced CFC emissions and the Montreal Protocol, J. Public Econom. 63, 331-339 (1997).

38. OECD, "Environmental Taxes in OECD Countries," Organization for Economic Cooperation and Development, Paris (1995).

39. OECD, "Producer Subsidy Equivalents and Consumer Subsidy Equivalents Database 1979-1996," Paris, Organization for Economic Co-operation and Development (1997). 
40. OECD, "Improving the Environment Through Reducing Subsidies. Part II," Organization for Economic Co-operation and Development, Paris (1998).

41. M. Olson, "The Logic of Collective Action," Harvard University Press, Cambridge, MA (1965).

42. R. Pethig, Pollution, welfare, and environmental policy in the theory of comparative advantage, J. Environ. Econom. Management 2, 160-169 (1976).

43. J. Potters and R. Sloof, Interest groups: A survey of empirical models that try to assess their influence, Euro. J. Pol. Economy 12, 403-42 (1996).

44. E.J. Ray, The determinants of tariff and nontariff trade restrictions in the United States, J. Pol. Economy 89, 105-121 (1981).

45. J. Schleich, Environmental quality with endogenous domestic and trade policies, Euro. J. Pol. Economy 15, 53-71 (1999)

46. J.A. Tobey, The effects of domestic environmental policies on patterns of world trade: An empirical test, Kyklos 43, 191-209 (1990).

47. D. Trefler, Trade liberalization and the theory of endogenous protection: An econometric study of U.S. import policy, J. Pol. Economy 101, 138-160 (1993).

48. UNCED, "Nations of the Earth Report," Vol. I - III, United Nations, Geneva (1992).

49. USDA, Estimates of producer and consumer subsidy equivalents: Government intervention in agriculture 1982-87, Statistical Bulletin \# 803, U.S. Department of Agriculture, Economic Research Service, Washington, DC (1990).

50. USDA, Government intervention in agriculture 1982-92, Statistical Bulletin \#913, Economic Research Service, U.S. Department of Agriculture, Washington, DC (1994a). 
51. USDA, "World Agriculture: Trends \& Indicators, 1961-91," CD-ROM, Department of Economics and Statistics, U.S. Department of Agriculture, Washington, DC (1994b).

52. A. Valdés, Surveillance of agricultural price and trade policy in Latin America during major trade policy reforms, World Bank Discussion Paper \#349, World Bank, Washington, DC (1996).

53. C. van Beers and J.C.J.M. van den Bergh, An empirical multi-country analysis of the impact of environmental policy on foreign trade flows, Kyklos 50, 29-46 (1997).

54. H. White, A heteroscedasticity-consistent covariance matrix estimator and a direct test for heteroscedasticity, Econometrica 48, 817-38 (1980).

55. World Bank, "World Tables,” World Bank, Washington, DC (1992).

56. World Bank, “World Development Indicators 1997," World Bank, Washington, DC (1997a).

57. World Bank, "Economic and Social Database," World Bank, Washington, DC (1997b). 
Table A.I Variable Definition and Data Sources

\begin{tabular}{|c|c|}
\hline Variable & Definition and source \\
\hline STRING & $\begin{array}{l}\text { Index of stringency of environmental regulations. Source: [10] and own } \\
\text { calculations based on [48]. }\end{array}$ \\
\hline$P S E$ & $\begin{array}{l}\text { Producer Subsidy Equivalent as a percentage of the total value of } \\
\text { production. }{ }^{\text {a }} \text { Source: [39] for OECD countries, unpublished OECD data } \\
\text { files for Hungary, Poland and Czech Republic, [52] for Latin American } \\
\text { countries, [49,50], PSE for Morocco was computed using unpublished } \\
\text { USDA data files. }\end{array}$ \\
\hline$G D P p c$ & Gross domestic product per capita in 1987 U.S. dollars. Source: [52]. \\
\hline$A G D P s h$ & Agriculture value added as a share of GDP (\%). Source: [56]. \\
\hline FERTph & Fertilizer consumption per hectare of arable land in $\mathrm{kg}$. Source: [56]. \\
\hline$A G L A N D s h$ & Agricultural land as a share from total land (\%). Source: [57]. \\
\hline AGLABORsh & Share of labor force in agriculture (\%). Source: [56]. \\
\hline VALUEph & $\begin{array}{l}\text { Agricultural value added per hectare of agricultural land in } 1987 \text { US\$. } \\
\text { Source: }[51] \text {. }\end{array}$ \\
\hline FREE & $\begin{array}{l}\text { The sum of the two indices of political rights and civil liberties. Source: } \\
{[19] .}\end{array}$ \\
\hline DEMOCRACYdummy & Dummy variable for democratic freedoms. Source: [19]. \\
\hline
\end{tabular}

${ }^{\mathrm{a}}$ Data for Thailand and Venezuela is from 1987.

b 1987 local currency GDP was converted to 1987 US\$ using the 1987 average exchange rates. 
Table A.II: Descriptive Statistics

\begin{tabular}{l|cccccc}
\hline & Mean & Median & Max. & Min. & Std. Dev. & Obs. \\
\hline STRING & 112.9 & 92.0 & 186.0 & 43.0 & 40.8 & 62 \\
PSE & 17.1 & 25.0 & 83.4 & -145.7 & 43.9 & 50 \\
GDPpc & 6416.7 & 2027.5 & 27653.0 & 80.0 & 7820.1 & 62 \\
AGDPsh & 14.6 & 10.1 & 48.0 & 1.8 & 12.7 & 62 \\
AGLANDsh & 45.9 & 51.3 & 84.8 & 1.1 & 21.8 & 62 \\
AGLABORsh & 30.8 & 18.4 & 94.1 & 2.2 & 27.4 & 62 \\
FERTph & 156.9 & 106.4 & 635.5 & 0.9 & 153.0 & 62 \\
VALUEph & 1030.6 & 398.5 & 13188.4 & 7.4 & 1991.5 & 62 \\
FREE & 5.5 & 4 & 14 & 2 & 3.5 & 62 \\
DEMOCRACYdummy & 0.6 & 1 & 1 & 0 & 0.5 & 62 \\
\hline
\end{tabular}


${ }^{\mathrm{i}}$ We thank Torbjörn Becker, Cees van Beers, Peter Christoffersen, William Donnelly, Stratford Douglas, Jerry Fletcher, Robert Inman, Bruce Gardner, Noel Gaston, John List, Leo Maier, Lisa Segnestam, Ronald Steenblik, David Wheeler, participants at presentations at West Virginia University, the World Bank Conference "Trade, Global Policy, and the Environment," Washington, DC, the CentER Workshop "Environmental Policy, Competitiveness and Locational Behavior of Firms," Schiermonnikoog, The Netherlands, and the Southern Economic Association Meetings, Baltimore, for constructive discussions and comments on earlier versions of this paper, and USDA for making data sources available. The two referees and the Associate Editor provided comments that led to a significantly improved final version. We also thank John Dixon for his support. Several of the theoretical results were (essentially) included in a paper (by the second author alone) presented at the EAERE Annual Conference at Tilburg University entitled "Why Don't Environmental Regulations Influence Trade Patterns?" Funding from the Swedish International Development Cooperation Agency (Sida) within the project "Trade, Macroeconomic Reform, and the Environment" and from the Department of Economics, University of Adelaide, is gratefully acknowledged. The opinions expressed are those of the authors and not necessarily those of the World Bank or Sida. The usual disclaimers apply.

${ }^{\text {ii }}$ Moreover, Grossman and Krueger [23] find that tariff free exports to the United States from the Mexican maquiladora sector were higher in sectors with high abatement costs in the United States. However, Hettige et al. [25] and Low and Yeats [33] report evidence of a migration of polluting industries from OECD to developing countries, and List and Co [32] find evidence that heterogeneous environmental policies across US states matter for FDI plant location decisions in the US. 
iii OECD [38] reports that Austria, Finland, and Sweden have introduced fertilizer and pesticide taxes and levies, and the revenues have been used to subsidize crops and exports. In the United States, the 1985 and 1990 Farm Bills and the Conservation Reserve Program (CRP) were primary forms of environmental programs in agriculture. Unless farmers refrained from cultivating highly erosive areas, all farm program payments were lost by the farm. Gardner [21] reports that CRP idled 36.5 million acres, approximately 10 percent of U.S. cropland acreage.

iv The finding also suggests that environmental regulations addressing agricultural environmental problems are distorted by government assistance closely associated with these regulations. We do not estimate the aggregate effects of transfers and regulations on trade patterns, nor do we study the effect on aggregate pollution levels of environmental policies and assistance programs. The environmental effects of commodity programs are relatively well known, see Just and Bockstael [28]. Since agricultural production is a significant contributor to environmental problems such as soil erosion, water pollution and and habitat loss (through, e.g., stimulating excessive use of pesticides and fertilizers, encouraging conversion of land to agricultural production, and reducing crop diversity), the results have implications for environmental policy (see Lewandrowski et al. [31]).

${ }^{v}$ Leidy and Hoekman [30] and Tobey [46] briefly discuss the possibility that new trade barriers may have emerged to offset the effects of more stringent environmental regulations.

${ }^{\text {vi }}$ Aidt [1] and Fredriksson [15] study the endogenous determination of pollution taxes and raw materials taxes, respectively. Aidt [1] discusses how the political process may 
result in an efficient policy for the government and the lobby groups. Fredriksson [16] focuses on pollution abatement subsidies and argues that these are primarily used for redistribution. Schleich [45] studies production and consumption externalities, and show that inefficient trade policies may lead to greater environmental quality than efficient domestic environmental policies. Fredriksson [17] explores the effects of trade liberalization on pollution taxes. Hillman and Ursprung [26] analyze the effect of environmental interests on trade policy in a model of political competition for elective office. They discuss the impact of the environmentalists' objectives, and the implications of production versus consumption externalities. Neither of the discussed papers studies the political economic relationship between environmental regulations, transfers, and trade patterns, however.

vii Corner solutions may emerge with quasi-linear preferences. We assume interior solutions, however.

${ }^{\text {viii }}$ An individual $k$ spending $Y^{k}$ consumes $c^{x}=d\left(p^{*}\right)$ and $c^{z k}=Y^{k}-p^{*} d\left(p^{*}\right)$. The indirect utility function of an environmentalist is expressed as $V^{E}\left(p^{*}, t, s, Y^{E}\right)=Y^{E}+C\left(p^{*}\right)-\theta X$, and for farmers and workers $V^{k}\left(p^{*}, t, s, Y^{k}\right)=Y^{k}+C\left(p^{*}\right), k=F, W$, where $C\left(p^{*}\right)=u\left[d\left(p^{*}\right)\right]-p^{*} d\left(p^{*}\right)$ is the consumer surplus derived from consumption of good $x$.

ix Thus, in the case of a deficit, the budget is balanced by a uniform lump sum tax on all individuals.

${ }^{\mathrm{x}}$ The number of lobby group members thus equals the fraction of the population, which is normalized to 1 . 
xi As discussed by Grossman and Helpman [22], the government values political contributions because these may be used for campaign spending or for personal use, and greater social welfare increases the probability of re-election in an implicitly modeled election.

${ }^{x i i}$ The lobby groups are assumed not to renege on their promises in the second stage. A subgame perfect Nash equilibrium is a set of contribution schedules and a policy such that each contribution schedule is feasible; the policy $t^{0}$ maximizes the government's welfare, taking the contribution schedules as given; and given the schedule of lobby group $j$ and the government's anticipated decision rule, no lobby group $i, i \neq j$, has a feasible strategy that results in a net payoff greater than the equilibrium net payoff.

xiii Condition (C1) requires that the government determines the tax-subsidy policy pair to maximize its own welfare, given the offered contribution schedules. Condition (C2) states that the equilibrium subsidy selected maximizes the joint welfare of each lobby $j$ and the government, given the other lobby's equilibrium schedule. This must be true since lobby $j$ could otherwise change its schedule to induce the government to select the jointly optimal subsidy, and capture most of the surplus from the policy change. Since the government would select the new policy, and lobby $j$ would benefit from the change, the original subsidy policy could not have been an equilibrium. For a complete set of necessary and sufficient conditions, see Bernheim and Whinston [7]. See also Dixit et al. [13] for a further discussion of the model.

${ }^{\text {xiv }}$ For consistency we keep both arguments where applicable. Eqn. (10) implies that at the equilibrium point the contribution schedules are locally truthful. Intuitively, each contribution schedule is determined so that the marginal change in the contribution for a 
small change in policy matches the effect of the policy on the lobby group's gross welfare, given a strictly positive contribution. The curvatures of the contribution schedules accurately represent the lobby groups' preferences around the equilibrium. See Dixit et al. [13] and Grossman and Helpman [22].

${ }^{x v}$ This simply implies that in Eqn (12) the farmers (environmentalists) favor a greater (smaller) production subsidy.

${ }^{x v i}$ Note that in a small open economy facing a given world market and domestic price, a change in domestic output translates directly into a change in trade flows as consumer demand is constant.

${ }^{x v i i}$ Further empirical investigation should explicitly study the joint effects on trade flows, taking into consideration, e.g., that some sub-sectors may be characterized by imperfect competition.

xviii The index can be decomposed into sub-indices. Dasgupta et al. [10] report that the correlations between the sub-indices range from 0.86 to 0.98 , and therefore the benefit of subjectively selecting the questions to use in our analysis appears small. Consequently, we opt to employ the index as it was originally constructed.

${ }^{\text {xix }}$ The PSE is calculated by adding indirect transfers from the government (e.g., budget expenditures, tax expenditures) to implicit transfers from consumers to producers. This sum is measured by multiplying the volume of domestic production by the gap between the domestic producer price and the border price.

${ }^{\mathrm{xx}}$ The PSE value for each individual EU member country was computed by multiplying the per-unit commodity PSE for the European Union as a whole with the quantities of the corresponding products in the country of interest. The final result was obtained by adding across commodities. 
xxi We are forced to exclude measures representing environmental pressures from the $P S E$ equation because soil erosion and fertilizer use have been found to be determined by the level of the PSE (see [31]).

${ }^{x x i i}$ Since the correlation coefficient between $A G D P$ sh and AGLABORsh is 0.84 both are not entered into the equation at the same time.

xxiii However, Bardhan [2, p.13] argues that in the agricultural sector, and in Southeast Asia in particular, free-rider problems are often overcome.

${ }^{\text {xxiv }}$ Our conceptual framework implies that all individuals in the economy exert a downward pressure on the level of government assistance in their role as taxpayers. For given level of transfers, the lower the budget resources the greater the marginal cost of subsidy transfers to the farm sector. Because of some 20 missing observations we dropped this variable in our final specification, however.

${ }^{\mathrm{xxv}}$ It appears that an increased relative economic importance of the agricultural sector translates into a greater political influence, which negatively affects the stringency of environmental regulations.

${ }^{\text {xxvi }}$ Using the Freedom House indices separately yields the same result.

xxvii Similar evidence of compensation has been reported in studies of other policy areas where various producer groups are "hurt". For example, Trefler [47] reports a positive correlation between trade protection and import penetration, Ray [44] finds that trade protection is greater in industries in which the U.S. has no comparative advantage, and Marvel and Ray [34] and Ray [44] show that industries suffering from lower tariffs due to trade-liberalization agreements have obtained nontariff trade barriers as compensation. Potters and Sloof [43, p. 419] sums up the evidence with "industries that are 
hurt"..."have an easier time to get 'compensating' protection. Hence, being in need"..."favors your case."

xxviii Aggregate agricultural subsidies were roughly the same in 1985 (\$7.6bn) and 1994 (\$7.8bn). The intermittent years had higher values, however, reaching a peak of $\$ 16.5 \mathrm{bn}$ in 1987 (EWG [14]).

${ }^{\text {xxix }}$ Our result is in contrast to Guttman [24] who found that producers' influence is greater when they are relatively many. On the other hand, Miller [36] found that the number of farmers has a negative impact on their political influence in developing countries but a positive impact in developed countries. As Potters and Sloof [43] point out, this relationship may be non-monotonic and dependent on interest group type.

${ }^{\mathrm{xxx}}$ This is similar to the findings by Gardner [20] for agricultural support policy.

${ }^{x x x i}$ Some anecdotal evidence exists from the industrial sector. OECD [40, p. 30] reports that Swedish industry, and particularly energy intensive industry sectors, have obtained substantial tax breaks on energy taxes. A 1993 reform even abolished the energy tax for industry, and provided a 75 percent exemption of the $\mathrm{CO}_{2}$ tax for industrial users. The latter tax was reduced to 50 percent in 1997. 


\section{APPENDIX}

Table 1A. Definition of regional trade agreements used in empirical analysis

$\begin{array}{ll}\text { ACP } & \text { Africa, Caribbean, and Pacific (EU Lome Convention) (1976) } \\ \text { ANCOM } & \text { Andean Common Market (the Andean Pact) (1969) } \\ \text { ANZCERT } & \text { Australia New-Zealand Free Trade Agreement (1966) } \\ \text { ATPA } & \text { Preferential Trade Agreement between USA and Andean countries } \\ \text { CACM } & \text { Central American Common Market (1960) } \\ \text { CARIBCAN } & \begin{array}{l}\text { Preferential Trade Agreement between Canada and } \\ \text { Commonwealth of Caribbean countries (1986) }\end{array} \\ \text { CARICOM } & \text { Caribbean Community and Common Market (1973) } \\ \text { CBI } & \text { Caribbean Basin Initiative (1984) } \\ \text { COMESA } & \text { Community of Eastern and Southern Africa (1981) } \\ \text { CUSTFA } & \text { Canada - US Free Trade Agreement (1989) } \\ \text { ECOWAS } & \text { Economic Community of West African States (1977) } \\ \text { EFTA } & \text { European Free Trade Association (1960) } \\ \text { EU } & \text { European Union } \\ \text { LAIA } & \text { Latin American Integration Agreement (1981) } \\ \text { MERCOSUR } & \text { Southern Common Market (1991) } \\ \text { NAFTA } & \text { North America Free Trade Agreement (1994) } \\ \text { SAARC } & \text { South Asian Association for Regional Cooperation (1985) } \\ \text { SPARTECA } & \text { South Pacific Regional Trade and Economic Agreement (1981) }\end{array}$


Table 2A.Variable Definition and Data Sources

\begin{tabular}{|c|c|}
\hline Variable & Definition and source \\
\hline \multirow{4}{*}{ STRING } & $\begin{array}{l}\text { Index of stringency of environmental regulations. Source: Dasqupta, et. al. } \\
\text { (1995) and own calculations based on UNCED, "Nations of the Earth }\end{array}$ \\
\hline & Report”, Vols. I-III, United Nations, Geneva (1992). \\
\hline & $\begin{array}{l}\text { Gross domestic product per capita in } 1987 \text { U.S. Dollars. Source: USDA. } \\
\text { "World Agriculture: Trends and Indicators, 1961-91", CD-ROM, }\end{array}$ \\
\hline & Department of Economics and Statistics, U.S. Department of Agriculture, \\
\hline \multirow[t]{2}{*}{ GDPpc } & Washington, DC (1994) \\
\hline & Gross national product per capita average annual growth rate 1980-1990. \\
\hline GNPgrowth & $\begin{array}{l}\text { Source: The World Bank, "World Development Indicators database. } \\
\text { Share of labor force in agriculture (\%). Source: The World Bank, "World }\end{array}$ \\
\hline AGLABORsh & Development Indicators database. \\
\hline \multirow[t]{2}{*}{$A G D P s h$} & $\begin{array}{l}\text { Agriculture value added as a share of GDP (\%). Source: The World Bank, } \\
\text { "World Development Indicators database. }\end{array}$ \\
\hline & Population density per sq. km. Source: The World Bank, "World \\
\hline \multirow[t]{2}{*}{ POPdensity } & Development Indicators database. \\
\hline & Agricultural land as a share from total land area (\%). Source: The World \\
\hline \multirow[t]{2}{*}{ AGLANDsh } & Bank, "World Development Indicators database. \\
\hline & Fertilizer consumption per hectare of arable land in kg. Source: The World \\
\hline \multirow[t]{2}{*}{ FERTph } & Bank, "World Development Indicators database. \\
\hline & $\begin{array}{l}\text { Dummy variable for trade openness. Source: Sachs, J.D. and A. Warner, } \\
\text { "Economic Reform and the Process of Global Integration", Brookings }\end{array}$ \\
\hline \multirow[t]{2}{*}{ OPENdummy } & Papers on Economic Activity, 26(1), pp. 1-118, (1995). \\
\hline & $\begin{array}{l}\text { Ratio of agricultural exports plus imports over agricultural GDP. Source: } \\
\text { own calculations based on the data from World Bank, "World }\end{array}$ \\
\hline \multirow[t]{2}{*}{ TRADEintensity } & Development Indicators database. \\
\hline & $\begin{array}{l}\text { Dummy variable for democratic freedoms. Source: Freedom House, } \\
\text { "Freedom in the World: Political Rights and Civil Liberties", Freedom }\end{array}$ \\
\hline \multirow[t]{2}{*}{ DEMOCRACY } & House, New York (1991). \\
\hline & $\begin{array}{l}\text { Dummy variable for democratic freedoms. Source: Freedom House, } \\
\text { "Freedom in the World: Political Rights and Civil Liberties", Freedom }\end{array}$ \\
\hline DEMOCRACYdummy & House, New York (1991). \\
\hline
\end{tabular}




\section{Index of the Stringency of Environmental Regulations}

Our index of the stringency of environmental regulations (STRING) was developed based on information collected from national environmental reports prepared for the 1992 United Nations Conference on Environment and Development in Rio de Janeiro. The reports were prepared based on a common guidelines and are thus similar in form and coverage, allowing cross-country comparisons.

The index was first developed by Dasgupta et al. (1995) for 31 countries, covering five sectors: agriculture, industry, energy, transport and the urban sector. It was extended to 62 countries using the same methodology as Dasgupta et al. but focusing only on agriculture sector. The reports consist information on the state of environmental policy performance along four dimensions: air, water, land and living resources. The information for the computation of aggregate indexes was collected based on a survey of twenty five questions [see Dasgupta, et. al. (1995) for full questionnaire]. The questions were categorized by the following categories: (i) environmental awareness; (ii) scope of policies adopted; (iii) scope of legislation enacted; (iv) control and enforcement mechanisms in place; and (v) the degree of success in implementation. The performance in each category was graded as "high", "medium" and "low" with assigned values of 2, 1, 0 respectively.

The composite index of environmental stringency was computed by adding scores within each environmental dimension. Table $3 \mathrm{~A}$ presents the individual scores for all four environmental dimensions and composite indexes for each country in the sample. 
Table 3A. Index of Stringency of Environmental Regulations in Agriculture Sector

\begin{tabular}{|c|c|c|c|c|c|c|}
\hline \multirow[b]{2}{*}{ Country } & \multicolumn{5}{|c|}{$\begin{array}{c}\text { Stringency of environmental regulations } \\
\text { (STRING) }\end{array}$} & \multirow[b]{2}{*}{ Source } \\
\hline & Total & Air & Water & Land & Living & \\
\hline Argentina & 80 & 11 & 19 & 27 & 23 & $1 /$ \\
\hline Australia & 163 & 32 & 43 & 45 & 43 & $1 /$ \\
\hline Austria & 169 & 39 & 43 & 43 & 44 & $1 /$ \\
\hline Bangladesh & 80 & 7 & 18 & 31 & 24 & $2 /$ \\
\hline Belgium & 162 & 31 & 44 & 43 & 44 & $1 /$ \\
\hline Brazil & 79 & 6 & 21 & 27 & 25 & $2 /$ \\
\hline Bulgaria & 138 & 28 & 37 & 37 & 36 & $2 /$ \\
\hline Canada & 171 & 39 & 42 & 45 & 45 & $1 /$ \\
\hline Chile & 90 & 10 & 25 & 28 & 27 & $1 /$ \\
\hline China & 105 & 9 & 21 & 38 & 37 & $2 /$ \\
\hline Colombia & 84 & 8 & 20 & 27 & 29 & $1 /$ \\
\hline Czechoslovakia & 94 & 21 & 25 & 25 & 23 & $1 /$ \\
\hline Denmark & 165 & 36 & 44 & 43 & 42 & $1 /$ \\
\hline \multicolumn{7}{|l|}{ Dominican } \\
\hline Republic & 77 & 8 & 21 & 25 & 23 & $1 /$ \\
\hline Ecuador & 84 & 10 & 22 & 25 & 27 & $1 /$ \\
\hline Egypt & 74 & 5 & 26 & 23 & 20 & $2 /$ \\
\hline Ethiopia & 49 & 2 & 11 & 17 & 19 & $2 /$ \\
\hline Finland & 177 & 40 & 45 & 47 & 45 & $2 /$ \\
\hline France & 161 & 30 & 43 & 43 & 45 & $1 /$ \\
\hline Germany & 182 & 42 & 48 & 48 & 44 & $2 /$ \\
\hline Ghana & 84 & 10 & 24 & 25 & 25 & $2 /$ \\
\hline Greece & 133 & 27 & 35 & 38 & 33 & $1 /$ \\
\hline Hungary & 101 & 11 & 31 & 31 & 28 & $1 /$ \\
\hline Iceland & 115 & 10 & 26 & 40 & 39 & $1 /$ \\
\hline India & 90 & 10 & 24 & 29 & 27 & $2 /$ \\
\hline Ireland & 170 & 33 & 45 & 46 & 46 & $2 /$ \\
\hline Italy & 146 & 27 & 41 & 41 & 37 & $1 /$ \\
\hline Jamaica & 87 & 12 & 26 & 26 & 23 & $2 /$ \\
\hline Japan & 162 & 29 & 46 & 45 & 42 & $1 /$ \\
\hline Jordan & 77 & 8 & 25 & 26 & 18 & $2 /$ \\
\hline Kenya & 84 & 8 & 24 & 27 & 25 & $2 /$ \\
\hline Korea, Rep. & 117 & 4 & 23 & 43 & 47 & $2 /$ \\
\hline Malawi & 76 & 6 & 23 & 24 & 23 & $2 /$ \\
\hline Mexico & 89 & 9 & 25 & 27 & 28 & $1 /$ \\
\hline Morocco & 77 & 8 & 24 & 25 & 20 & $1 /$ \\
\hline Mozambique & 62 & 3 & 17 & 22 & 20 & $2 /$ \\
\hline Netherlands & 165 & 35 & 41 & 44 & 45 & $2 /$ \\
\hline New Zealand & 157 & 29 & 40 & 45 & 43 & $1 /$ \\
\hline Nigeria & 71 & 6 & 15 & 26 & 24 & $2 /$ \\
\hline Norway & 173 & 34 & 45 & 47 & 47 & $1 /$ \\
\hline Pakistan & 91 & 11 & 25 & 29 & 26 & $2 /$ \\
\hline Papua New Guinea & 68 & 2 & 19 & 23 & 24 & $2 /$ \\
\hline
\end{tabular}




\begin{tabular}{lcccccc}
\hline Paraguay & 77 & 5 & 23 & 25 & 24 & $2 /$ \\
Philippines & 78 & 6 & 17 & 27 & 28 & $2 /$ \\
Poland & 112 & 16 & 33 & 34 & 29 & $1 /$ \\
Portugal & 139 & 27 & 34 & 39 & 39 & $1 /$ \\
Senegal & 76 & 6 & 23 & 24 & 23 & $1 /$ \\
South Africa & 115 & 10 & 30 & 39 & 36 & $2 /$ \\
Spain & 144 & 27 & 39 & 40 & 38 & $1 /$ \\
Sweden & 181 & 42 & 46 & 46 & 47 & $1 /$ \\
Switzerland & 186 & 43 & 48 & 47 & 48 & $2 /$ \\
Tanzania & 72 & 2 & 17 & 27 & 26 & $2 /$ \\
Thailand & 76 & 3 & 18 & 28 & 27 & $2 /$ \\
Trinidad and & & & & & & \\
Tobago & 93 & 10 & 24 & 31 & 28 & $2 /$ \\
Tunisia & 105 & 15 & 30 & 31 & 29 & $2 /$ \\
Turkey & 78 & 8 & 23 & 27 & 20 & $1 /$ \\
United Kingdom & 172 & 35 & 44 & 46 & 47 & $1 /$ \\
United States & 185 & 43 & 48 & 47 & 47 & $1 /$ \\
Uruguay & 88 & 11 & 26 & 28 & 23 & $1 /$ \\
Venezuela & 87 & 12 & 22 & 25 & 28 & $1 /$ \\
Zambia & 78 & 8 & 23 & 24 & 23 & $2 /$ \\
Zimbabwe & 83 & 6 & 24 & 28 & 25 & $1 /$ \\
\hline
\end{tabular}

1/ Own calculations

2/ Dasgupta, S., A. Mody, S. Roy, and D. Wheeler. 1995. Environmental regulation and Development: A Cross-Country Empirical Analysis." The World Bank, Policy Research Working Paper No. 1448 
Table 4A. Descriptive Statistics of Variables

\begin{tabular}{lccccc}
\hline Variable & Mean & Median & Std. Dev. & Min. & Max. \\
\hline STRING & 113.0 & 92.0 & 40.7 & 49 & 186 \\
GDPpc & $6,415.6$ & $2,027.5$ & 7,821 & 80 & 27,653 \\
GNPgrowth & 1.4 & 1.5 & 1.9 & -2.3 & 7.8 \\
AGLABORsh & 30.7 & 18.4 & 27.2 & 2.2 & 86.6 \\
AGDPsh & 14.7 & 10.1 & 12.9 & 1.8 & 49.3 \\
DEMOCRACY & 2.9 & 3 & 1.7 & 1 & 7 \\
DEMOCRACYdummy & 0.6 & 1 & 0.5 & 0 & 1 \\
TRADEintensity & 1.0 & 0.7 & 1.3 & 0.0 & 8.4 \\
OPENdummy & 0.5 & 0 & 0.5 & 0 & 1 \\
POPdensity & 411.7 & 167.4 & $1,180.3$ & 5.3 & 9,323 \\
AGLANDsh & 46.6 & 51.6 & 21.3 & 1.1 & 84.8 \\
FERTph & 156.9 & 106.4 & 152.9 & 0.9 & 635.5 \\
\hline
\end{tabular}


Table 5A. A Sample of Spatial Weight Matrix Based on Custom Unions

\begin{tabular}{|c|c|c|c|c|c|c|c|c|c|c|c|c|}
\hline & Belgium & Colombia & Germany & Ecuador & France & $\begin{array}{c}\text { Great } \\
\text { Britain }\end{array}$ & Jamaica & Kenya & Portugal & $\begin{array}{c}\text { Trinidad \& } \\
\text { Tobago }\end{array}$ & Tanzania & Zambia \\
\hline Belgium & 0 & 0 & 1 & 0 & 1 & 1 & 0 & 0 & 1 & 0 & 0 & 0 \\
\hline Colombia & 0 & 0 & 0 & 1 & 0 & 0 & 0 & 0 & 0 & 0 & 0 & 0 \\
\hline Germany & 1 & 0 & 0 & 0 & 1 & 1 & 0 & 0 & 1 & 0 & 0 & 0 \\
\hline Ecuador & 0 & 1 & 0 & 0 & 0 & 0 & 0 & 0 & 0 & 0 & 0 & 0 \\
\hline France & 1 & 0 & 1 & 0 & 0 & 1 & 0 & 0 & 1 & 0 & 0 & 0 \\
\hline Great Britain & 1 & 0 & 1 & 0 & 1 & 0 & 0 & 0 & 1 & 0 & 0 & 0 \\
\hline Jamaica & 0 & 0 & 0 & 0 & 0 & 0 & 0 & 0 & 0 & 1 & 0 & 0 \\
\hline Kenya & 0 & 0 & 0 & 0 & 0 & 0 & 0 & 0 & 0 & 0 & 1 & 1 \\
\hline Portugal & 1 & 0 & 1 & 0 & 1 & 1 & 0 & 0 & 0 & 0 & 0 & 0 \\
\hline $\begin{array}{l}\text { Trinidad \& } \\
\text { Tobago }\end{array}$ & 0 & 0 & 0 & 0 & 0 & 0 & 1 & 0 & 0 & 0 & 0 & 0 \\
\hline Tanzania & 0 & 0 & 0 & 0 & 0 & 0 & 0 & 1 & 0 & 0 & 0 & 1 \\
\hline Zambia & 0 & 0 & 0 & 0 & 0 & 0 & 0 & 1 & 0 & 0 & 1 & 0 \\
\hline
\end{tabular}

Custom Unions:

EU - Belguim, Germany, France, Great Britain, Portugal; ANCOM - Colombia, Ecuador;

COMESA - Kenya, Tanzania, Zambia;

CARICOM - Jamaica, Trinidad \& Tobago 


\section{Table 6A. List of Variables}

\begin{tabular}{|c|c|c|c|c|c|c|c|c|c|c|c|c|c|}
\hline Obs. & Country & STRING & GDPpc & GNPgrowth & AGLABORsh & AGDPsh & POPdensity & AGLANDsh & FERTph & $\begin{array}{c}\text { OPEN } \\
\text { dummy }\end{array}$ & $\begin{array}{c}\text { TRADE } \\
\text { intensity }\end{array}$ & DEMOCRACY & $\begin{array}{c}\text { DEMOCRACY } \\
\text { dummy }\end{array}$ \\
\hline 1 & Argentina & 80 & 2,318 & -1.98 & 12.15 & 8.12 & 17.57 & 61.90 & 6.62 & 0 & 0.72 & 3 & 1 \\
\hline 2 & Australia & 163 & 13,062 & 1.41 & 5.52 & 3.33 & 5.31 & 60.46 & 24.29 & 1 & 1.34 & 1 & 1 \\
\hline 3 & Austria & 169 & 17,182 & 2.21 & 7.76 & 3.12 & 192.33 & 42.31 & 212.48 & 1 & 1.03 & 1 & 1 \\
\hline 4 & Bangladesh & 80 & 173 & 2.36 & 65.24 & 36.85 & 974.86 & 79.79 & 97.76 & 0 & 0.12 & 5 & 0 \\
\hline 5 & Belgium & 162 & 15,882 & 1.97 & 2.64 & 1.85 & 39.00 & 45.19 & 501.31 & 1 & 8.41 & 1 & 1 \\
\hline 6 & Brazil & 79 & 1,903 & 0.18 & 23.34 & 10.43 & 82.12 & 28.48 & 69.39 & 0 & 0.42 & 3 & 1 \\
\hline 7 & Bulgaria & 138 & 2,320 & 2.08 & 13.46 & 17.75 & 75.74 & 55.71 & 176.23 & 0 & 0.75 & 4 & 0 \\
\hline 8 & Canada & 171 & 16,686 & 1.57 & 3.37 & 2.73 & 14.18 & 8.00 & 45.21 & 1 & 1.38 & 1 & 1 \\
\hline 9 & Chile & 90 & 1,744 & 2.19 & 18.75 & 9.01 & 54.08 & 23.63 & 73.05 & 1 & 0.70 & 2 & 1 \\
\hline 10 & China & 105 & 318 & 7.76 & 72.24 & 27.05 & 898.03 & 53.24 & 289.72 & 0 & 0.25 & 7 & 0 \\
\hline 11 & Colombia & 84 & 1,234 & 1.55 & 26.62 & 16.24 & 336.34 & 44.08 & 200.83 & 0 & 0.37 & 4 & 0 \\
\hline 12 & Czechoslovakia & 94 & 3,328 & 1.37 & 11.21 & 7.30 & 114.00 & 52.68 & 262.53 & 0 & 0.71 & 2 & 1 \\
\hline 13 & Denmark & 165 & 20,657 & 1.62 & 5.56 & 4.71 & 30.44 & 65.77 & 246.67 & 1 & 2.38 & 1 & 1 \\
\hline 14 & Dominican Republic & 77 & 698 & 0.51 & 24.83 & 13.42 & 282.37 & 74.20 & 84.56 & 0 & 0.71 & 3 & 1 \\
\hline 15 & Ecuador & 84 & 1,145 & -0.06 & 33.26 & 13.41 & 287.32 & 28.34 & 41.91 & 0 & 0.51 & 2 & 1 \\
\hline 16 & Egypt & 74 & 725 & 3.84 & 40.29 & 19.37 & $1,288.09$ & 2.66 & 422.42 & 0 & 0.40 & 4 & 0 \\
\hline 17 & Ethiopia & 49 & 120 & -1.40 & 86.18 & 49.27 & 421.00 & 53.43 & 7.00 & 0 & 0.14 & 7 & 0 \\
\hline 18 & Finland & 177 & 19,961 & 3.05 & 8.39 & 7.30 & 75.65 & 8.75 & 174.16 & 1 & 0.36 & 1 & 1 \\
\hline 19 & France & 161 & 17,276 & 1.88 & 5.49 & 3.41 & 81.96 & 55.57 & 315.74 & 1 & 1.69 & 2 & 1 \\
\hline 20 & Germany & 182 & 15,646 & 2.00 & 3.98 & 2.00 & 97.54 & 51.63 & 273.33 & 1 & 2.93 & 2 & 1 \\
\hline 21 & Ghana & 84 & 363 & -0.83 & 59.31 & 44.85 & 364.04 & 54.52 & 4.82 & 0 & 0.22 & 5 & 0 \\
\hline 22 & Greece & 133 & 4,919 & 1.49 & 22.95 & 20.43 & 147.72 & 71.06 & 241.75 & 1 & 0.95 & 2 & 1 \\
\hline 23 & Hungary & 101 & 2,414 & 0.99 & 15.22 & 13.93 & 77.73 & 70.11 & 132.77 & 0 & 0.74 & 2 & 1 \\
\hline 24 & Iceland & 115 & 20,693 & 2.19 & 10.97 & 10.11 & 342.16 & 22.75 & 136.00 & 1 & 0.33 & 1 & 1 \\
\hline 25 & India & 90 & 363 & 2.72 & 64.02 & 30.98 & 381.56 & 60.89 & 75.87 & 0 & 0.05 & 3 & 1 \\
\hline 26 & Ireland & 170 & 10,217 & 2.52 & 14.34 & 10.00 & 121.17 & 74.76 & 555.17 & 1 & 1.98 & 1 & 1 \\
\hline 27 & Italy & 146 & 14,392 & 2.51 & 8.60 & 3.22 & 209.58 & 57.27 & 215.76 & 1 & 1.21 & 1 & 1 \\
\hline
\end{tabular}




\begin{tabular}{|c|c|c|c|c|c|c|c|c|c|c|c|c|c|}
\hline 28 & Jamaica & 87 & 1,334 & -0.37 & 24.76 & 6.47 & 742.48 & 43.95 & 121.66 & 0 & 2.10 & 2 & 1 \\
\hline 29 & Japan & 162 & 22,883 & 3.53 & 7.28 & 2.54 & 677.49 & 13.93 & 446.25 & 1 & 0.43 & 1 & 1 \\
\hline 30 & Jordan & 77 & 1,340 & 0.74 & 15.27 & 8.08 & 327.23 & 13.39 & 51.61 & 1 & 1.56 & 5 & 0 \\
\hline 31 & Kenya & 84 & 381 & 1.02 & 79.52 & 29.14 & 443.14 & 45.33 & 29.00 & 0 & 0.37 & 6 & 0 \\
\hline 32 & Korea, Rep. & 117 & 3,932 & 6.76 & 18.11 & 8.69 & 575.10 & 22.25 & 468.99 & 1 & 0.54 & 3 & 1 \\
\hline 33 & Malawi & 76 & 200 & -0.35 & 86.65 & 43.51 & 457.23 & 37.31 & 29.25 & 0 & 0.85 & 6 & 0 \\
\hline 34 & Mexico & 89 & 1,731 & 1.30 & 27.92 & 7.18 & 99.18 & 53.55 & 77.69 & 0 & 0.65 & 4 & 0 \\
\hline 35 & Morocco & 77 & 841 & 1.44 & 44.67 & 17.70 & 140.11 & 68.12 & 36.62 & 1 & 0.38 & 4 & 0 \\
\hline 36 & Mozambique & 62 & 80 & -1.71 & 82.73 & 44.54 & 358.17 & 60.11 & 0.90 & 0 & 0.43 & 6 & 0 \\
\hline 37 & Netherlands & 165 & 15,769 & 1.52 & 4.57 & 4.04 & 192.22 & 59.14 & 635.50 & 1 & 4.64 & 1 & 1 \\
\hline 38 & New Zealand & 157 & 10,846 & 0.54 & 10.36 & 6.82 & 20.09 & 64.76 & 141.50 & 1 & 2.02 & 1 & 1 \\
\hline 39 & Nigeria & 71 & 386 & -2.26 & 43.01 & 32.71 & 211.69 & 79.14 & 13.55 & 0 & 0.08 & 5 & 0 \\
\hline 40 & Norway & 173 & 19,433 & 2.50 & 6.28 & 3.16 & 135.98 & 3.18 & 232.16 & 1 & 0.55 & 1 & 1 \\
\hline 41 & Pakistan & 91 & 346 & 3.55 & 51.80 & 25.98 & 373.52 & 33.65 & 92.41 & 0 & 0.27 & 4 & 0 \\
\hline 42 & Papua New Guinea & 68 & 850 & -0.73 & 79.19 & 28.97 & $9,323.29$ & 1.07 & 351.43 & 0 & 0.41 & 3 & 1 \\
\hline 43 & Paraguay & 77 & 932 & 1.92 & 39.02 & 27.78 & 102.58 & 58.64 & 8.49 & 0 & 0.73 & 3 & 0 \\
\hline 44 & Philippines & 78 & 730 & 0.11 & 45.76 & 21.90 & 584.86 & 34.85 & 107.32 & 0 & 0.31 & 3 & 0 \\
\hline 45 & Poland & 112 & 1,540 & 0.50 & 27.47 & 8.26 & 101.21 & 61.73 & 121.80 & 0 & 0.35 & 2 & 1 \\
\hline 46 & Portugal & 139 & 4,053 & 3.17 & 17.82 & 6.18 & 277.32 & 43.84 & 117.32 & 1 & 1.27 & 2 & 1 \\
\hline 47 & Senegal & 76 & 643 & -0.42 & 76.72 & 17.93 & 187.02 & 42.04 & 5.14 & 0 & 0.70 & 3 & 0 \\
\hline 48 & South Africa & 115 & 2,152 & -0.11 & 13.54 & 5.30 & 129.05 & 78.36 & 58.76 & 1 & 0.56 & 4 & 0 \\
\hline 49 & Spain & 144 & 8,576 & 2.00 & 11.86 & 4.63 & 62.30 & 61.01 & 128.85 & 1 & 1.00 & 1 & 1 \\
\hline 50 & Sweden & 181 & 19,866 & 1.60 & 3.80 & 3.00 & 50.84 & 8.29 & 115.38 & 1 & 0.82 & 1 & 1 \\
\hline 51 & Switzerland & 186 & 27,653 & 1.74 & 5.52 & 3.07 & 691.80 & 51.10 & 429.41 & 1 & 1.16 & 1 & 1 \\
\hline 52 & Tanzania & 72 & 152 & 1.11 & 84.40 & 48.00 & 667.19 & 43.70 & 16.94 & 0 & 0.16 & 5 & 0 \\
\hline 53 & Thailand & 76 & 1,221 & 5.57 & 64.06 & 12.74 & 258.30 & 41.85 & 59.67 & 1 & 0.75 & 3 & 1 \\
\hline 54 & Trinidad and Tobago & 93 & 3,460 & 0.25 & 11.04 & 2.56 & 516.11 & 25.54 & 105.41 & 0 & 2.20 & 1 & 1 \\
\hline 55 & Tunisia & 105 & 1,450 & 1.83 & 28.14 & 15.72 & 118.12 & 52.85 & 28.50 & 0 & 0.55 & 4 & 0 \\
\hline 56 & Turkey & 78 & 1,364 & 1.69 & 53.08 & 18.30 & 88.36 & 51.55 & 76.58 & 0 & 0.34 & 4 & 0 \\
\hline 57 & United Kingdom & 172 & 12,827 & 2.12 & 2.17 & 1.88 & 94.96 & 73.96 & 358.71 & 1 & 2.57 & 2 & 1 \\
\hline 58 & United States & 185 & 19,283 & 1.53 & 2.87 & 2.05 & 33.30 & 46.62 & 100.07 & 1 & 0.73 & 1 & 1 \\
\hline
\end{tabular}




\begin{tabular}{|c|c|c|c|c|c|c|c|c|c|c|c|c|c|}
\hline 59 & Uruguay & 88 & 2,393 & 0.52 & 14.25 & 11.33 & 27.26 & 84.80 & 57.05 & 0 & 0.89 & 2 & 1 \\
\hline 60 & Venezuela & 87 & 2,484 & -2.19 & 12.02 & 5.40 & 104.71 & 25.11 & 143.29 & 0 & 0.39 & 3 & 1 \\
\hline 61 & Zambia & 78 & 263 & -2.34 & 74.61 & 18.20 & 85.83 & 47.44 & 11.33 & 0 & 0.33 & 5 & 0 \\
\hline 62 & Zimbabwe & 83 & 635 & 0.82 & 68.17 & 16.33 & 256.58 & 51.71 & 64.96 & 0 & 1.06 & 4 & 0 \\
\hline
\end{tabular}




\section{PAAVO ELISTE}

\section{EDUCATION}

WEST VIRGINIA UNIVERSITY

Morgantown, West Virginia

Ph.D. (Environmental Economics)

- Major: Environmental and natural resource economics; Minor: Public finance (in Department of Economics).

- Dissertation topic: Three empirical essays on environmental regulations, strategic interaction, and regional trade arrangements;

WEST VIRGINIA UNIVERSITY

M.S. (Agricultural and Natural Resources Economics)
Morgantown, West Virginia Aug. 1993 to June 1995

- Major: Natural resources economics; environmental policy analysis

- Received Rotary International Graduate Scholarship for two years full time study.

ESTONIAN AGRICULTURAL UNIVERSITY

B.S. (Animal Sciences)

Tartu, Estonia

1988-May 1993

\section{WORK EXPERIENCE}

\section{THE WORLD BANK}

Natural Resources Economist:
Washington, D.C. From 1998 to present

Worked extensively on projects related to natural resources management (Armenia and China); biodiversity conservation (Kyrgyz Republic and Indonesia); rural development and agricultural modernization (China); and poverty reduction (Armenia and China). Responsibilities include project preparation and design; implementation support; project management; preparation of national environmental strategies and sector studies; economic and financial analysis (enterprise, project and market level); benefit cost analysis; incremental cost analysis; and monitoring and evaluation of project impacts.

Participated in the supervision of environmental management projects portfolio in Estonia, Latvia, and Lithuania. Main responsibilities include municipal water utility financial analysis and evaluation of economic value of environmental benefits.

UNDP and SOROS FOUNDATION

Consultant/Environmental Economist
Tallinn, Estonia From November 2001 to April 2002

Estonia Sustainable Development Indicators Project. Assisted Estonian Public Policy Research Centre PRAXIS in the development of methodologies for integration of sustainable development indicators into the System of National Accounts (Green Accounting). Advised senior officials of relevant government agencies and sectoral ministries in mainstreaming sustainable development principles into national and sectoral policy 
making process. Contributed to the development of discussion of issues related to sustainable development at a societal level through building partnerships with NGOs and relevant stakeholders from private and public sector. Organized presentations and discussions with policy makes.

\section{WEST VIRGINIA UNIVERSITY}

Teaching Assistant:

$$
\begin{gathered}
\text { Morgantown, West Virginia } \\
\text { Jan. - May } 1998
\end{gathered}
$$

- Developed and taught an upper level undergraduate course in Environmental and Natural Resource Economics.

- Research in the area of political economy of environmental regulations.

\section{THE WORLD BANK}

Summer Intern: The Indicators and Environmental Valuation Unit (ENVPE)
Washington, D.C. May - Dec. 1997

- Participated in the Bank's inter-sectoral project "Trade, Macro Reform, and the Environment" with a focus on the analysis of key issues in the debate on trade and the environment.

- Participated in the Unit's work in mainstreaming the environmental indicators into the Bank's operational processes.

- Participated in the Bank's Green National Accounts work program.

\section{WEST VIRGINIA UNIVERSITY}

Research Assistant:
Morgantown, West Virginia Aug. 1995 to May 1997

- Research, data acquisition, database management, and economic analysis related to various environmental and natural resource policy issues.

- Spatial analysis of agro-environmental indicators of land use in the Baltic States.

- Preparation of spatially referenced data sets using Geographical Information Systems (GIS).

- Evaluation of environmental benefits from recreational activities in the Matsalu State Nature Reserve in Estonia.

\section{THE WORLD BANK}

Summer intern: Europe and Central Asia Region (EC4NR).

Washington, D.C. May-Aug 1994

- Preparation of the Estonian Agriculture and Forestry Rehabilitation Loan Project.

- Contributed to the Agricultural Sector Report and the Staff Appraisal Report.

- Collection and updating of economic data on the field.

- Preparation of the baseline loan costs tables using Costab software.

\section{PUBLICATIONS AND PAPERS}

Eliste, Paavo and Per Fredriksson. Environmental Regulations, Transfers and Trade:

Theory and Evidence. Journal of Environmental Economics and Management, Vol. 43, No. 2, Mar 2002, pp. 234-250.

Eliste, Paavo and Per Fredriksson. Does Open Trade Cause Race to the Bottom: An Empirical Evidence. In Luc Anselin and Raymond J.G.M. Florax (editors), New Advances in Spatial Econometrics, Springer Verlag, (forthcoming in 2002).

Cohen, Bruce C., Walter C. Labys, and Paavo Eliste. 2001. An econometric time-series analysis of global CO2 concentrations and emissions. International Journal of Environment and Pollution 15,4: 371385 . 
Eliste, Paavo and Per Fredriksson. The Political Economy of Environmental Regulations, Government Assistance, and Foreign Trade: Theory and Evidence. In P. Fredriksson (editor), Trade, Global Policy and the Environment. The World Bank Discussion Paper No. 402, 1999.

Phipps, T.T. and Paavo.Eliste. Agriculture and the Environment in Transition: A Case Study of Estonia. In J.M. Antle, J.N. Lekakis and G.P. Zanias (editors), Agriculture, Trade, and Environment: The Impact of Liberalization on Sustainable Development, Edward Elgar, 1998.

\section{PROFESSIONAL ACTIVITIES}

- Member of the Association of Environmental and Resource Economists

- Member of the American Agricultural Economics Association

\section{LANGUAGES}

Speaking Reading Writing

$\begin{array}{llll}\text { Estonian } & \text { Native } & & \\ \text { English } & \text { Fluent } & \text { Fluent } & \text { Fluent } \\ \text { Russian } & \text { Good } & \text { Good } & \text { Fair }\end{array}$

